\title{
KASTEN ÖLDÜRME SUÇU (TCK m. 81)
}

\author{
Berrin AKBULUT ${ }^{*}$
}

\section{$\ddot{O} Z$}

Kasten öldürme suçu Türk Ceza Kanununun (TCK'nın) 81, 82 ve 83. maddelerinde hükme bağlanmıştır. 81. maddede öldürme suçunun temel şekli, 82. maddede suçun daha fazla ceza verilmesini gerektiren nitelikli şekli, 83. maddede ise suçun ihmali şekilde işlenmesi düzenlenmiştir. Çalışma konusu 81. maddeyle sınırlı olup, 82. ve 83. madde hükümleri ayrı bir incelemede değerlendirilecektir.

TCK'nın 81. maddesinde düzenlenen kasten öldürme suçu serbest hareketli suçtur. Suçun oluşabilmesi için öldürme neticesinin gerçekleşmesi gerekir. Suç, düzenleme itibariyle mağdur ve fail açısından bir özellik göstermemektedir. Ancak suçun oluşması için insan hayatının ne zaman başladığının ve ne zaman sona erdiğinin belirlenmesi gerekir. Hayatın ne zaman başladı̆̆ konusunda doktrinde çeşitli görüşler ileri sürülmüştür. Suçun, doğrudan kastla ve olası kastla işlenmesi mümkündür. Ancak failin kastının yaralamaya mı öldürmeye mi yönelik olduğunun belirlenmesi önem arzetmektedir. Hukuka uygunluk nedenlerinin uygulanması söz konusu olabilmektedir. Ötenazi ise mevzuatımızda kabul edilmemiştir. Suçun teşebbüs halinde kalması ve iştirak halinde işlenmesi mümkün olup fikri içtima ve gerçek içtima da gerçekleşebilir.

Çalışmada suçla korunan hukuki değer, suçun unsurlarl, teşebbüs, iştirak ve içtima konuları incelenecektir. Bu kapsamda özellikle hayatın ne zaman başlayıp sona erdiği, nedensellik bă̆g çerçevesinde objektif isnadiyet, manevi unsura ilişkin belirlemeler ve buna ilişkin Yargıtay uygulamaları, hukuka aykırılık bağlamında silah kullanma yetkisi ve meşru savunma konuları değerlendirilmeye çalışılacaktır.

Anahtar Kelimeler: yaşam hakkl, ölüm, objektif isnadiyet, kast, ötenazi.

THE CRIME OF WILFUL MURDER (TPC Art. 81)

\section{ABSTRACT}

Wilful murder is regulated in articles 81,82, and 83 of the Turkish Penal Code (TPC). The basic form of the crime of wilful murder is regulated in article 81, the

" Prof. Dr., Selçuk Üniversitesi Hukuk Fakültesi e-posta: bakbulut@selcuk.edu.tr

ORCID ID: 0000-0001-8045-2784

DOI : 10.34246/ahbvuhfd.812996
Yayın Kuruluna Ulaştığı Tarih
: 06/09/2020

Yayınlanmasının Uygun Görüldüğü Tarih: 28/09/2020

Ankara Hacı Bayram Veli Üniversitesi Hukuk Fakültesi Dergisi C. XXIV, Y. 2020, Sa. 4273 
qualified case of the crime requiring more punishment in article 82, and committing the crime negligently in article 83. The subject of study is limited to Article 81, and the provisions of Articles 82 and 83 will be evaluated in another examination.

The crime of wilful murder regulated in Article 81 of the TPC is an offence with free act. The result of the murder needs to be happened for the crime to occur. The crime has not any characteristic in terms of victim and perpetrator as the regulation. However, for the crime to occur, it is necessary to determine when the human life begins and ends, and in the doctrine, various views are suggested about when the life begins. It is possible that the crime is committed by direct intent or eventual intent. Nevertheless, it is important to determine whether the perpetrator's intention is to injure or to kill. It is possible to apply the reasons for compliance with the law. Euthanasia is not accepted in our legislation. The criminal attempt and the accomplicity can be possible in this crime and also conceptual aggregation or actual aggregation can be applied to this crime.

In the study, legal value protected by crime, elements of crime, criminal attempt, accomplicity, and aggregation of crime will be examined. In this context, especially when the life begins and ends, objective imputation subject to the relation of causality, determinations related to the moral element, and the relevant Supreme Court of Appeals decisions, the authority to use weapons in the context of unlawfulness, and legitimate defence issues will be evaluated.

Keywords: the right to life, death, objective imputation, intent, euthanasia.

\section{GíRiş}

Kasten öldürme “en”lerin suçudur. En temel hakk1 korumakta, en eski suç niteliği taşımakta, ceza hukukunun en temel suçlarından birini teşkil etmekte, şiddet içeren suçların en başında gelmekte ve en ağırını oluşturmaktadır. Kasten öldürme fiili önemi nedeniyle her dönemde suç olarak kabul edilmiş, uluslararası sözleşmelerde de yaşam hakkını korumak için belirlemeler yapılmıştır.

Öldürme suçu, insan yaşamını sona erdiren bir fiildir. $\mathrm{Bu}$ nedenle bireysel değerleri koruyan suçların en başında gelmekte ve yaptırımı da diğer kişilere karşı işlenen suçlara göre daha ağır olarak belirlenmektedir. Tarihi süreç içinde de ceza hukukunda yaşanan gelişmelere paralel olarak cezalarında farklı belirlemelerin yapıldığı görülmektedir. 5237 sayılı Türk Ceza Kanununda da öldürme suçu İkinci Kısımda Hayata Karşı Suçlar 
başlığını taşıyan Birinci Bölümde düzenlenmiş ve suçun cezası da müebbet hapis olarak öngörülmüştür. Bu bölüm toplam beş maddeden oluşmaktadır. İlk üç maddesi (m. 81, 82, 83) kasten öldürmeyi, 4. maddesi intihara yönlendirmeyi (m. 84), son maddesi (m. 85) ise taksirle öldürmeyi hükme bağlamaktadır. TCK'nın 81. maddesinde kasten öldürme suçunun temel şekli, 82. maddesinde kasten öldürme suçunun daha fazla ceza verilmesini gerektiren nitelikli şekli, 83. maddesinde ise kasten öldürme suçunun ihmali davranışla işlenmesi hükme bağlanmıştır. Düzenlemelerde kasten öldürmenin daha az ceza verilmesini gerektiren nitelikli şekline ise yer verilmemiştir. Kasten öldürmenin dolaylı faillik şeklinde işlenmesi de mümkün olup kanun koyucu dolaylı faillik şekillerinden ikisine kasten öldürmeye ilişkin maddelerde değil intihara yönlendirmenin düzenlendiği TCK'nın 84. maddenin 4. fikrasında yer vermiştir. İnceleme konumuz 81 . madde olup aşağıda bu maddeye ilişkin açıklamalara yer verilecektir.

\section{Genel Olarak}

Öldürme suçu, ilk insandan itibaren görülen bir suç şekli olması nedeniyle hukukumuzda da her zaman suç olarak nitelendirilmiş ve cezalandırılmıştır. Çin kaynaklarından edinilen bilgilere göre Göktürk Devletinde, cana kast, insan öldürme suçunun cezası ölüm olarak uygulanmıştır. Osmanlı Hukukunda da bir kişiyi öldürme, suç olarak kabul edilmekteydi' ${ }^{1}$. Osmanlı hukuku, iki sisteme dayanmaktaydı. Biri İslam hukuku, diğeri örfi sultani hukuktur². İslam hukukunda öldürme suçu kısas ve diyet gerektiren (kulun haklarına karşı işlenen) suçlardan sayılmaktayd1 ${ }^{3}$. Kasten öldürme niteliğindeki fiil, cinayetünnefis, yani katil olarak nitelendirilmekteydi ${ }^{4}$. Padişahların sırf kendi iradesiyle kanun yapma yetkisi için kullanılan örfi sultani hukuk adı verilen bu hukuk düzeni, eski Türk devlet geleneğinin bir çeşit yansıması olarak ortaya çıkmışıır'. Aynı zamanda İslam hukukunun tamamlanması amacıyla

İslam hukukunda katlin beş çeşidi bulunmaktadır: Amden katil, şibih amd, hataen katil, hata mecrasına câri katil, tesebbüben katil. Bkz.: Dönmezer/Erman, C. I, 2016, s. 154; Gökcen, s. 6.

2 Gökcen, s. 3.

3 Kısas, öldürme ve yaralama suçlarından dolayı mağdurda meydana gelen zarar miktarında ve aynı şekilde faile zarar verilmesini ifade etmektedir. Diyet ise, öldürme ve yaralama suçlarından dolayı mağdura veya varislerine mal olarak verilen tazminatı karşılamaktadır. Ayrıntılı bilgi için bkz.: Akbulut, 2019, s. 62.

4 Dönmezer, s. 11.

5 Üçok, s. 68.

Ankara Hacı Bayram Veli Üniversitesi Hukuk Fakültesi Dergisi C. XXIV, Y. 2020, Sa. 4275 
da başvurulmuş bir yoldur. Bu nedenle Osmanlı İmparatorluğu dönemi boyunca örfi hukuk şer'i hukuk yanında uygulanmıştır ${ }^{6}$. Ayrıca Osmanlı İmparatorluğunda çeşitli nedenlerle yaşanan olumsuzlukların giderilmesi için reform hareketleri başlamış, bu çerçeve de kanunlar da yapılmıştır. $\mathrm{Bu}$ gelişmeler açısından öldürme suçuna bakıldığında Fatih Sultan Mehmet Kanunnamesinde (m. 13), II. Bayezid Umumi Kanunnamesinde (m. 14), Bozok Kanununda (m. 21), Kanuni Sultan Süleyman Kanunnamesinde (m. 16) ve Dördüncü Mehmet Kanunnamesinde öldürmeye ilişkin hükümlere yer verildiği tespit edilmektedir. Kanunnamelerde öldürmenin cezası kısas olarak ifade edilmiş, kısas talebinden vazgeçilmişse tazir türünden para cezası öngörülmüştür ${ }^{7} .1256$ (1840) tarihli Ceza Kanunnamei Hümayununda, 1267 (1851) tarihli Kanunu Ceditte ve 1274 (1858) tarihli Ceza Kanunnamei Hümayununda da öldürme suçuna yer verilmiştir ${ }^{8}$. 1256 tarihli Kanunun birinci faslında öldürme suçu düzenlenmekte ve kısasın uygulanmas1 konusunda failin vezir olmasiyla halktan biri olması arasında herhangi bir farkın bulunmadığı belirtilmekteydi. Suçun İstanbul'da işlenmesi halinde davanın Şeyhülislam huzurunda görüleceği, taşrada işlenmesi halinde meşveret meclisinde görüleceği, Meşihat Makamının tasdikinden ve padişahın onayı alındıktan sonra cezanın infaz edileceği düzenlenmekteydi. 1267 (1851) tarihli Kanunu Ceditte ise öldürme suçu Evvelki Faslın 14. ve 15. maddelerinde düzenlenmekteydi. 14. maddesinde öldürme suçunu işleyenin, azmettirenin ve yardım edenin nasıl cezalandırılacağ 1 (azmettiren ve yardım eden için hapis cezası öngörülmekteydi), 15. maddede ise kadınların öldürme suçunu işlemeleri halinde nasıl cezalandırılacağı, faile bir kadının yardımcı olması halinde ıslahı nefs edinceye kadar hapis cezasıyla cezalandırılacağı hükme bağlanmaktaydı ${ }^{9} .1274$ tarihli Kanunda ise ikinci babın birinci faslında 168-175. maddeler arasında öldürme suçu düzenlenmekteydi. 168. maddede öldürme suçu, "Katl, gerek silah ile ve gerek tesmim ile ve gerek suver-i uhra ile bir şahsı idam etmektir" (öldürme, gerek silahla, gerek zehirlemek suretiyle ve gerekse diğer şekillerde bir kimsenin öldürülmesi) şeklinde tanımlanmıştır. 169. maddede tasarlayarak öldürmenin tanımı, 170. maddede tasarlayarak öldürmenin cezası (idam), 171. maddede maktulün mirasçılarının hukuk mahkemesinde açacakları şahsi hukuk davası, 172. maddede ölüm

\footnotetext{
Gökcen, s. 9, 10.

Avc1, s. 299.

8 Dönmezer, s. 11.

9 Gökcen, s. 20, 24.
}

276 Ankara Hacı Bayram Veli Üniversitesi Hukuk Fakültesi Dergisi C. XXIV, Y. 2020, Sa. 4 
cezası affolunan kişinin müebbeten veya 15 seneden az olmamak üzere kürek cezasına mahkum olacağı, 173. maddede dolaylı faillik suretiyle öldürme suçunun işlenmesi (siyaseten katil cezasıyla cezalandırılıyor), 174. maddede cezanın daha fazla verilmesini gerektiren nitelikli haller ve 175 . maddede ise yardım etme (muvakkaten kürek cezası) düzenleniyordu ${ }^{10}$.

Kasten öldürme suçu 765 sayılı Kanunda ise 2. Kitap 9. Babta Şahıslara Karşı Cürümlerin birinci faslında düzenlenmişti (448, 449, 450, 451, 453. maddelerde). Bu Kanunun 448. maddesinde suçun temel şekli düzenlenmekte ve cezası da 24 seneden 30 seneye kadar hapis cezası olarak öngörülmekteydi. 448 ve 449. maddelerde ise suçun daha fazla ceza verilmesini gerektiren nitelikli halleri yer alıyordu. 451. madde suçun daha az ceza verilmesini gerektiren nitelikli halini, 453. madde ise yeni doğmuş çocuğun öldürülmesi fiilini düzenleniyordu. Ayrıca geçen fasıllara ait müşterek hükümler başlığını taşıyan üçüncü faslın 462. ve 463. maddeleri öldürme fiiliyle de ilgiliydi ${ }^{11}$. 765 sayılı Kanunun 448. maddesi hükmü inceleme konumuz olan 5237 say1lı Türk Ceza Kanununun 81. maddesi düzenlemesiyle karşılaştırıldığında, 765 sayılı Kanunun süreli hapis cezası öngördüğü (24-30 yıl) 5237 sayılı Kanunun ise müebbet hapis cezası öngördügü görülmektedir. 765 sayılı Kanun mağduru bir kimse olarak ifade ederken 5237 sayılı Kanun bir insan olarak belirtmektedir. Ayrıca 81. madde düzenlemesiyle ilgili olduğu için diğer bir fark da dolaylı faillikle ve öldürmenin ihmali şekilde işlenmesine ilişkin özel bir düzenlemeye 765 sayılı Kanunda yer verilmezken, 5237 sayılı Kanunda açıkça hükme bağlanmasıdır (m. 83, m. 84/4).

\section{Korunan Hukuki Değer}

Kasten öldürme suçuyla korunan hukuki değer yaşam hakkıdır ${ }^{12}$. Yaşam hakkı, en temel haktır. Hakların en önemlisi ve diğer hakların varlık sebebi, özü olarak ifade edilmektedir. Kişinin dokunulamaz, devredilemez ve vazgeçilemez haklarından biri olup anayasalarda ve uluslararası sözleşmelerde koruma altına alınmıştır ${ }^{13}$.

10 Gökcen, s. 147, 148.

11 462. madde 5237 sayılı Kanun yürürlüğe girmeden önce 15.07.2003 tarihindeki 4928 say1l1 Kanunla yürürlükten kaldırılmıştır. 463. madde ise doğru olarak 5237 sayılı Kanuna alınmamıştır.

12 Kasten öldürmenin benzer suçlarla kıyaslanmasına ilișkin olarak bkz.: Gökcen/Balc1, (2013), s. 17 vd.; Artuk/Gökcen, Özel Hükümler, s. 47, 48. Ayrıca mukayeseli hukuk için bkz.: Gökcen/Balc1, (2013), s. 7 vd.

13 Koca/Üzülmez, Özel Hükümler, s. 67. 
Yaşama hakkının varlık nedenini, insanın doğal olmayan ölüme karş1 korunması oluşturmaktadır ${ }^{14}$. Yaşama hakkının korunması, diğer temel hakların kullanılabilmesi için de zorunludur ${ }^{15}$. Kanun koyucu bireysel hakları bireyselüstü haklardan daha önemli görmüş ve önceliği kişilere karşı suçlara vermiştir. Kişilere karşı suçları düzenlerken de yaşam hakkını bireysel değerlerin en önemlisi olarak kabul etmiş ve TCK' da kişilere karşı suçların ilk suçu olarak hükme bağlamıştır. Yaşam hakkı, savaş, seferberlik veya olağanüstü dönemlerde bile savaş hukukuna uygun fiiller sonucu meydana gelen ölümler dışında dokunulamayacak bir hak olarak görülmektedir (AY m. 15; AİHS m. 15).

Devletin kişinin yaşama hakkını koruma yükümlülüğü kapsamında negatif yükümlülüğü, pozitif yükümlülüğ̈̈ ve soruşturma yükümlülüğü (usuli nitelikte pozitif yükümlülük olarak nitelendirilmekte) bulunmaktadır. Negatif yükümlülüğünü öldürmeme yükümlülügü, pozitif yükümlülüğünü kişilerin hayatını koruma yükümlülüğü, soruşturma yükümlülüğünü ise doğal olmayan, şüpheliölümhallerindeetkin soruşturmayapmayükümlülüğüoluşturmaktadır ${ }^{16}$. Devlet bu yükümlülüklerini yerine getirmek için düzenlemeler yapmakta ve yaşam hakkını korumaya çalışmaktadır. Bu düzenlemelerden bir tanesi de TCK'nın 81-83. maddelerindeki düzenlemelerdir. Aynı zamanda düzenlemeler getirilirken yaşama müdahalenin hangi hallerde hukuka uygun sayılacağı da gösterilmektedir (Anayasa m. 17; Avrupa İnsan hakları Sözleşmesi m. 2).

\section{Suçun Unsurları}

\section{A. Maddi Unsurlar}

\section{Fail ve Mağdur}

\section{a)Fail}

Suçun faili herkes olabilir. TCK'nın 81. maddesinde, öldüren kişi ifadesiyle herhangi bir kişinin suçu işleyebileceği kabul edilmiştir. Kadın, erkek, çocuk herhangi bir kişi suçun faili olabilir. Ancak fail ile mağdur arasındaki belli derecede akrabalık ilişkisi (TCK m. 82/1-d) suçun nitelikli hali olarak düzenlenmiştir.

Kişinin kendisini öldürmesi mevzuatımızda suç olarak kabul edilmemiştir. Yaşamına son verme veya intihar etme bir hak olarak henüz

\footnotetext{
14 Doğru, s. 7.

15 Gökcen/Balc1, (2013), s. 5.

16 Ayrıntılı bilgi için bkz.: Doğru, s. 41 vd.
} 
kabul edilmemekle birlikte kişinin kendisini öldürmesi de cezalandırılan bir fiil kapsamında değildir ${ }^{17}$.

\section{b)Mağdur}

Öldürülen kişi mağdurdur. Fiilin işlendiği esnada kişinin yaşıyor olması şartıyla herhangi bir kişi suçun mağduru olabilecektir. Ölen kişinin kim olduğu önemli değildir. Irkı, hastalığı, milliyeti, inancı vb. önemli olmaksızın herkesin yaşam hakkı korunmaktadır. Ölecek kişinin kasten öldürülmesi de öldürme suçunu oluşturur. Ancak ölen kişinin Cumhurbaşkanı olması m. 310'da ayrı bir suç olarak düzenlendiğinden TCK'nın öldürmeye ilişkin suçları öldürülen kişinin Cumhurbaşkanı olması halinde uygulanmayacaktır. Kanun koyucu temsil ettiği makam itibariyle, suçun Cumhurbaşkanını kişi olarak hedef alan bir fiil olmadığını, anayasal düzene ve bu düzenin işleyişini hedef aldığını kabul ederek bu bölümde düzenlemiştir. Kanun koyucu 310. maddede Cumhurbaşkanı yanında toplumu oluşturan herkesin de mağdur olduğunu kabul etmiştir. Cumhurbaşkanı dışındaki kişilere karşı gerçekleştirilen öldürme fiilleri ise kasten öldürme suçu kapsamında sorumluluk doğuracaktır.

Kural olarak öldürülen kişinin kim olduğu önemli değilse de kanun koyucu suçun bazı kişilere karşı gerçekleştirilmesini nitelikli hal olarak kabul etmiştir. Mağdurun üstsoy veya altsoydan biri olması veya eş ya da kardeşe karşı işlenmesi, çocuğa ya da beden veya ruh bakımından kendisini savunamayacak durumda bulunan kişiye karşı gerçekleştirilmesi, gebe olduğu bilinen kadına yönelik icra edilmesi, suçun daha fazla ceza verilmesini gerektiren nitelikli halini oluşturmaktadır. Yine kişinin yerine getirdiği kamu görevi nedeniyle öldürülmesi suçun daha fazla ceza verilmesini gerektiren nitelikli halini meydana getirmektedir.

Öldürülen kişinin yakınları suçtan zarar görendir.

Mağdur ancak bir kişi olabileceğinden, anne karnındaki cenini öldürmeye yönelik fiiller öldürme suçu kapsamında olmayıp çocuk düşürtme ve düşürme fiilleri (TCK m. 99, 100) kapsamında sorumluluk doğuracaktır.

\section{Suçun Konusu}

Öldürülen kişinin hayatı suçun konusunu oluşturmaktadır. Dolayısıyla suçun işlenebilmesi için yaşayan bir insanın bulunması gerekir. Kişinin hayatının suçun konusunu oluşturabilmesi için insan hayatının başlamış

17 Hak olmadığına ilişkin olarak bkz.: Koca/Üzülmez, Özel Hükümler, s. 68. 
ve sona ermemiş olması gerekir. İnsan hayatının henüz başlamadığı anne karnındaki cenine veya insan hayatının sona erdiği ölmüş kişiye karşı bu suç işlenemez ${ }^{18}$.

İnsan hayatının ne zaman başladığı doktrinde tartışmalıdır. Bir görüşe göre, doğumun başlamış olması yeterli olup, bu andan itibaren çocuk suçun konusunu oluşturacaktır. Normal doğumda sancıların başlaması, sezeryan doğumda ana rahminin açılmasıyla birlikte doğum başlamıştır ${ }^{19}$. Diğer görüşe göre, kasten öldürme suçunun gerçekleştirilmesi için ceninin anne karnından kısmen de olsa ayrılmış olması yeterlidir. Dolayısıyla bu andan itibaren çocuk suçun konusunu oluşturacaktır ${ }^{20}$. Diğer görüşe göre ise, tam ve sağ doğumun gerçekleşmesi halinde çocuk öldürme suçuna konu olabilecektir ${ }^{21}$. Yargıtay da tam doğumun gerçekleşmesini aramaktadır. AİHM, yaşama hakkının ne zaman başladığını tespit yetkisinin Sözleşmeci devletlerin takdir alanına girdiğini kabul etmekte, ancak doğacak çocuğa Sözleşme'nin 2. maddesi anlamında 'yaşama hakkı' tanımamaktadır. Mahkemeye göre ulusal hukukta doğmamış bebeğin yaşama hakkına sahip olduğu kabul edilse dahi, bu hak annenin yaşamından ve sağllğından üstün tutulamaz ${ }^{22}$.

Çocuğun canlı doğması yeterli olup, şekil bozukluğuna sahip olup olmaması önemli değildir. Sağ doğan çocuk da öldürme suçunun konusunu oluşturabilir. Yaşama şansının olup olmaması önemli değildir ${ }^{23}$. Ancak çocuğa müdahale etmeyen doktor için ihmali şekilde öldürmeden sorumluluk tayin edilmesi söz konusu olabilirse de burada yükümlülüğe aykırılık ilişkisinin bulunmaması (objektif isnadiyetin bulunmaması) nedeniyle ihmali şekilde öldürmeden doktoru sorumlu tutmanın söz konusu olmadığı belirtilmelidir. Hekim, tıbbi müdahalede bulunsa bile neticenin yine de gerçekleşeceği hallerde isnadiyet söz konusu değildir. Diğer görüşe göre yaşama şansına sahip olmayan çocuk kısa süre yaşasa da öldürme suçunun konusunu oluşturmaz ${ }^{24}$.

18 Koca/Üzülmez, Özel Hükümler, s. 69.

19 Tezcan/Erdem/Önok, s. 134; Özbek/Doğan/Bacaksı,, Özel Hükümler, s. 107, 108.

20 Dönmezer, s. 12; Gökcen/Balc1, MÜHF-HAD, s. 124.

${ }^{21}$ Centel/Zafer/Çakmut, Kişilere Karşı İşlenen Suçlar, s. 28; Koca/Üzülmez, Özel Hükümler, s. 70; Hakeri, Kasten Öldürme Suçları, s. 21; Hafızoğulları/Özen, Özel Hükümler, s. 34; Bayraktar, s. 62.

22 Doğru, s. 8.

${ }^{23}$ Centel/Zafer/Çakmut, Kişilere Karşı İşlenen Suçlar, s. 28; Tezcan/Erdem/Önok, s. 135; Gökcen/Balc1, MÜHF-HAD, s. 124; Erman/Özek, no. 9.

24 Bu görüş için bkz.: Gökcen/Balc1, MÜHF-HAD, s. 124. 
Ancak ceninin canlı doğduktan sonra düşürtme fiiline bağlı olarak ölmesi halinde çocuk düşürtme suçu söz konusu olacaktır ${ }^{25}$.

İnsan hayatı kişinin ölümü ile sona erer. Bu andan itibaren artık yaşam hakkının varlığı söz konusu değildir. Ölüm, Mezarlık Yerlerinin İnşası ile Cenaze Nakil ve Defin Isslemleri Hakkında Yönetmeliğin 4. maddesinde tıbben kalp ve beyin ölümünün gerçekleşmesi olarak ifade edilmiştir. Organ ve Doku Nakli Hizmetleri Yönetmeliğinde beyin ölümü tanımlanmamışsa da (m. 4) beyin ölümü gerçekleşen kişiden organ veya doku alınacağ1 ifade edilerek beyin ölümü gerçekleşen kişinin öldüğü kabul edilmektedir (m. 14, 19). Ancak Organ ve Doku Nakli Hizmetleri Yönetmeliğinin Ek 1 düzenlemesinde beyin ölümü tanımlanmış ve beyin ölümünün klinik bir tanı olduğu ve tüm beyin fonksiyonlarının tam ve geri dönüşümü olmayan kaybı anlamına geldiği ifade edilmiştir ${ }^{26}$. Kalp ölümü veya klasik ölüm ise,

25 Hakeri, Tip Hukuku, (2015), s. 861, 862.

26 Beyin ölümü tanısında gereken ön koşullar şu şekilde belirtilmiştir: a) Komanın nedeninin belirlenmiş olması, b) Beyin hasarının yaygın ve geri dönüşümsüz olduğunun belirlenmiş olmas1, c) Santral vücut 1sısı $\geq 32$ oC olması, ç) Hipotansif şok tablosu olmamas1, d) Komadan geriye dönüşüm sağlanabilecek ilaç etkileri ve intoksikasyonların dışlanmış olması, e) Beyin hasarından bağımsız şekilde klinik tabloyu açıklayabilecek metabolik, elektrolit ve asit-baz bozukluklarının olmaması. (2) Birinci fikrada yer alan tüm koşulların tespiti halinde beyin ölümü tanısı için aşağıdaki hususlar aranır. a) Derin komanın olması (Tam yanıtsızlık hali; Santral ağrılı uyaranlara motor cevap alınamaması), b) Beyin sapı reflekslerinin alınmaması; 1) Pupiller parlak ışığa yanıtsız, orta hatta ve dilatedir (4-9 mm), 2) Okülosefalik ve Vestibulo-oküler refleks yokluğu, 3) Kornea refleksi yokluğu, 4) Faringeal ve trakeal reflekslerin yokluğu. c) Spontan solunum çabasının bulunmaması ve apne testinin pozitif olmasi. (3) Apne testi yapılabilmesi için normotermi, normotansiyon ve normovolemi ön koşulları sağlanır. Bu koşullarda hastaya uygun mekanik ventilasyon yaklaşımı ile PaCO2'nin 35-45 mmHg ve $\mathrm{PaO} 2$ 'nin 200 mmHg üzerinde olması sağlanmalıdır. Bu koşullar sağlandıktan sonra hasta mekanik solunum desteğinden ayrılarak intratrakeal oksijen uygulanmalıdır. Test sonunda $\mathrm{PaCO} 2 \geq 60 \mathrm{mmHg}$ ve/veya $\mathrm{PaCO} 2$ bazal değerine göre 20 $\mathrm{mmHg}$ veya daha fazla yükselmesine rağmen spontan solunumu yoksa apne testi pozitiftir. (4) Pnomotoraks, pnomomediastinum gibi apne testinin yapılmasının mümkün olmadığ tıbbi durumlarda, hekimler kurulunun belirleyeceği beyin dolaşımının durduğunu değerlendiren bir destekleyici test yapılır ve test sonucu beyin ölümü tanısı ile uyumlu ise beyin ölümü tespiti tamamlanır. (5) Aşağıdaki bulgular beyin ölümü tanısına engel oluşturmaz. a) Derin tendon reflekslerinin alınması, b) Yüzeyel reflekslerin alınması, c) Babinski işaretinin bulunması, ç) Spinal refleks ve otomatizmaların olması, d) Terleme, kızarma, ateş ve taşikardi bulunması, e) Diabetes insipitus olmaması. (6) Beyin ölümü tanısı konan vakalarda; a) Beyin ölümü tanısının konulduğu birinci nörolojik muayenedeki klinik tablonun; yeni doğanda ( 2 aydan küçük) 48 saat, 2 ay-1 yaş arası 24 saat, 1 yaş ve üzerindeki çocuklarda ve yetişkinlerde 12 saat ve anoksik beyin ölümlerinde 24 saat sonra yapılan ikinci nörolojik muayenede de değişmeden devam ettiği gözlenmelidir. b) Klinik beyin ölümü tanısı almış vakalarda, yeni doğan (2 aydan küçük) grubunda iki adet destekleyici test, 2 ay ve üzerindeki diğer vakalarda ise hekimler kurulunun uygun göreceği bir laboratuvar yöntemi ile beyin ölümü tanısı teyit edilir. c) Klinik olarak beyin ölümü tanısı konulan vakalar için beyin dola- 
solunum ve kalbin durması karşılığında kullanılmaktadır. Ancak bu ölümün de geri döndürülemez şekilde gerçekleşmesi gerekir ${ }^{27}$. Her iki ölüm şeklinin gerçekleşmesi durumunda artık öldürme suçunun varlığı söz konusu olmaz. Organ ve Doku Alınması, Saklanması, Aşılanması ve Nakli Hakkında Kanun, beyin ölümü kavramını kullanmamakla beraber, tıbbi ölüm kavramına yer vermektedir (beyin ölümü kapsamında kullanıldığı anlaşılmaktadır) ${ }^{28}$. Söz konusu Kanun, tıbbi ölümün gerçekleştiğine, biri nörolog veya nöroşirürjiyen, biri de anesteziyoloji ve reanimasyon veya yoğun bakım uzmanından oluşan iki hekim tarafından kanıta dayalı tıp kurallarına uygun olarak oy birliği ile karar verileceğini hükme bağlamaktadır. Bitkisel hayat ölüm olarak kabul edilmemektedir. Dolayısıyla bitkisel hayatta olan bir kişinin öldürülmesi kasten öldürme kapsamına girecektir. AİHM, geçirdiği kaza nedeniyle bitkisel hayata giren ve uzun süredir bilinçsiz durumda olan, midesinden beslenip su ihtiyacı karşılanan, tedaviye cevap vermeyen kişinin durumunu ölüm olarak kabul etmemiş, tıbbi desteğe son vermenin öldürmek olmayıp ölümün doğal sürecinin başlamasına imkan vermek ve ıstıraptan kurtarmak olduğu görüşünü (ülke görüşünü) benimsemiş ve 2. madde anlamında yaşam hakkının ihlali olarak nitelendirmemiştir ${ }^{29}$.

Konu açısından kişinin hayatta bulunması gerektiğinden ölmüş birine öldürmek için ateş edilmesinde konu bulunmamaktadır. Doktrinde bazı yazarlar tarafindan konunun bulunmadığ 1 durumlarda konunun yokluğu bulunduğu, bu durumda da işlenemez suçun söz konusu olduğu ifade edilmektedir ${ }^{30}$.

\section{Fiil}

Öldürme suçuna ilişkin düzenlemede harekete ilişkin bir belirleme yapılmamış, sadece netice belirtilmiştir. Dolayısıyla kasten öldürme suçu serbest hareketli bir suçtur. Ölümü meydana getirmeye elverişli herhangi bir hareketle suç işlenebilir. Herhangi bir araç kullanılabilir. Örneğin, yumruk, tekme, bıçak, silah, zehir, taş, sopa, demir çubuk, otomobil, eller gibi araçlarla

Şımını değerlendiren bir destekleyici test yapılmış ve yapılan bu test beyin ölümü ile uyumlu ise ikinci nörolojik muayene için beklemeye gerek kalmaz.

27 Doktrinde klasik ölüm tanısının yeterli bir kıstas olmadığı, solunumun ve dolaşımın bazı teknik aletler ve metodlarla bu fonksiyonlarını bazen sürdürebildikleri, bu nedenle tıpta yeni bir ölüm kıstasıarayışına gidildiği ve beyin ölümü kıstasının ortaya çıktığı belirtilmiştir: Artuk/Gökcen, Özel Hükümler, s. 49, 50; Bayraktar, s. 183, 184.

28 Aynı yönde Özbek/Doğan/Bacaksı,, Özel Hükümler, s. 110.

29 Doğru, s. 11

30 Soyaslan, Teşebbüs Suçu, s. 112; Özgenç, Türk Ceza Hukuku, s. 510. 
suç işlenebilir ${ }^{31}$. Maddi olmayan, manevi araçlarla da suçun işlenebileceği kabul edilmektedir ${ }^{32}$. Ancak pratikte bunu tespit etmenin çok zor olduğu da belirtilmektedir ${ }^{33}$. Öldürme olayının internet aracılığıyla da gerçekleştirildiğini görmekteyiz (mavi balina örneğinde olduğu gibi -dolaylı faillikle ilgili olarak). Virüs bulaştırmak suretiyle de işlenebilir. Ancak kanun koyucu suçun bazı hareketlerle gerçekleştirilmesini nitelikli hal olarak kabul etmiştir. TCK m. 82'de suçun tasarlayarak, eziyet çektirerek, yangın, su baskını, tahrip, batırma veya bombalama ya da nükleer, biyolojik veya kimyasal silah kullanmak suretiyle işlenmesi cezanın daha fazla verilmesini gerektiren nitelikli hal olarak düzenlenmiştir.

Öldürme suçunun söz konusu olması için hareketin öldürme fiilini gerçekleștirmeye elverişli olması gerekir. Hareketin elverişliliğinin tespitinde kullanılan araç da belirleyici olabilmekle birlikte yalnızca ona bakılması yeterli değildir. Elverişlilik fiilin gerçekleştirildiği şartlara göre yapılacaktır. Hâkim, fiilin gerçekleştirildiği andaki objektif bir gözlemcinin bilgi ve öngörüsünü esas alarak normal hayat tecrübelerine göre hareketin tipikliği gerçekleştirebileceğini mümkün görüyorsa hareket öldürme suçu açısından elverişli kabul edilecek, aksi takdirde elverişsiz hareket söz konusu olacaktır. Örneğin tabanca, bıçak, zehir gibi araçlar öldürme suçu için elverişli hareket niteliğindeyken ${ }^{34}$ büyü veya beddua ${ }^{35}$ veya ada çay1 gibi araçlar öldürme suçu için elverişsiz hareket kapsamındadır. Öldürmek kastıyla silahın etki mesafesi dışından ateş edilmesi halinde elverişli hareket söz konusu değildir ${ }^{36}$. Elverişliliğgin tespitinde ayrıca failin özel bilgisi varsa bu da dikkate alınacaktır ${ }^{37}$. Örneğin şeker hastası olduğunu bildiği birine şeker verilmesi veya hemofili hastası olduğunu bildiği kişinin yaralanması olaylarında elverişli hareket söz konusudur ${ }^{38}$.

31 Koca/Üzülmez, Özel Hükümler, s. 73.

32 Hafızoğullar1/Ketizmen, s. 144

33 Dönmezer, s. 14; Önder, Şahıslara ve Mala Karşı Cürümler, s. 8.

34 Koca/Üzülmez, Özel Hükümler, s. 73.

35 Artuk/Gökcen, Özel Hükümler, s. 48.

36 Özgenç, Türk Ceza Hukuku, s. 509.

37 Genel olarak bkz.: Soyaslan, Teşebbüs Suçu, s. 110; Sözüer, s. 187; Alacakaptan, İşlenemez Suç, s. 61, 62; Centel/Zafer/Çakmut, Türk Ceza Hukuku, s. 466, 467; Artuk/Gökcen, Genel Hükümler, s. 619; Demirbaş, s. 465-467; Özgenç, Türk Ceza Hukuku, s. 509; Koca/Üzülmez, Genel Hükümler, s. 427.

38 Özgenç, Türk Ceza Hukuku, s. 509; Koca/Üzzülmez, Genel Hükümler, s. 427; Sözüer, s. 187; Artuk/Gökcen, Genel Hükümler, s. 619. 
Fail, öldürme fiilini kendisi gerçekleştirebileceği gibi bir başkasına da cebir veya tehdit etkisiyle suçu gerçekleştittirebilir. Mağdurun kendisine de bunu yaptırabilir. Bu halde dolaylı faillik söz konusudur. Kanun koyucu dolaylı faillik yoluyla bir kişinin öldürülmesi açısından bazı hareketleri TCK m. 84/4 düzenlemiştir. Belirtilenlerin dışında da dolaylı faillik söz konusu olabilir ve dolaylı fail öldürme suçundan sorumlu tutulabilir. Örneğin, bir doktorun hemşireye ağrı kesici iğne yapması için gerçekte içinde öldürücü zehir bulunan şırıngayı vermesi ve hemşirenin ilacı enjekte etmesi sonucu hastanın ölmesi durumunda doktor hastanın ölümünden dolayı dolaylı fail olarak sorumlu olacaktır ${ }^{39}$. Suçun işlenmesinde bir hayvandan da yararlanılabilir. Bu halde ise doğrudan faillik söz konusu olur. Belirli şekilde hareket etme yükümlülüğü bulunan kişinin hareket etmek istemesine rağmen bunu gerçekleştirmesinin bir başkası tarafindan engellenerek neticenin gerçekleştiği hallerde engel olan kişinin fail olarak sorumluluğu kabul edilmekle beraber doğrudan fail mi yoksa dolaylı fail mi olduğu doktrinde tartışmalıdır ${ }^{40}$.

Fiil icrai olabileceği gibi ihmali de olabilir. Ancak öldürmenin ihmali şekilde işlenmesi 83. maddede düzenlendiğinden ihmali hareket bu çalışma kapsamında incelenmeyecektir.

\section{Netice}

Kasten öldürme suçu neticeli bir suçtur. Suçun oluşması için ölüm neticesinin gerçekleşmesi gerekir. Kanun koyucu bunu öldürme kavramıyla ifade etmiştir. Ölümün gerçekleşmediği, ancak icra hareketlerinin yapıldığ olayda fiil teşebbüs halinde kalmıştır.

Daha önce de ifade edildiği gibi ölüm kalp ölümü şeklinde olabileceği gibi beyin ölümü şeklinde de gerçekleşebilir. Her iki halde de kasten öldürme suçunun netice unsuru gerçekleşmiş sayılacaktır.

Kasten öldürme suçundaki ölüm neticesi, zarar şeklinde netice niteliğindedir.

\section{Nedensellik Bağı}

\section{a) Genel Olarak}

Kasten öldürme suçu neticeli bir suç olduğundan hareket ile netice arasında nedensellik bağının kurulması gerekmektedir. Ancak bu tür suçlarda

\footnotetext{
39 Öztürk/Erdem, s. 417.

40 Bkz.: Hakeri, Ceza Hukukunda İhmal Kavramı, s. 284, 285; Özgenç, Suça İştirakin, s. 254.
} 
failin sorumluluğu için yalnızca nedensellik bağının kurulması yetmemekte, ayrıca neticenin failin fiilinin eseri olduğunun tespiti yani objektif isnadiyetin varlığ da gerekmektedir. Tabi bilimler anlamında nedensellik ilişkisi kurulduktan sonra normatif olarak objektif isnadiyet kriterlerine göre ikinci bir değerlendirme yapılmaktadır. Buna göre objektif olarak isnad edilen her netice hareketin sonucudur, fakat hareketin neden olduğu her netice objektif olarak isnad edilebilir değildir ${ }^{41}$. Ceza Hukuku doktrinindeki eski görüşler, nedensellik bağının tespitiyle suçun maddi unsurlarının gerçekleştiğini kabul etmekteydi. Ancak cezalandırmanın adil olmayacağının anlaşıldığ hallerde, kasten işlenen icrai suçlarda kastın bulunmadığ 1 ileri sürülerek ceza verilmemekteydi. Örneğin A, öldürmek amaciyla B'ye ateş eder ve hafif yaralanan B, hastanede çıkan yangın nedeniyle ölür. Burada öldürmeye teşebbüs olduğu herkes tarafından kabul edilmekle birlikte kastın nedensel süreci de kapsamas1 gerektiği, olayda ise bu olmadığ için gerçekleşen sonuçtan failin sorumlu tutulamayacağ 1 belirtilmekteydi ${ }^{42}$. Sorun sübjektif unsurla aşılmaya çalışılıyordu. Ancak zamanla sorunun kast sorunu olmadığı, objektif isnadiyet sorunu olduğ $\mathrm{u}^{43}$ ifade edilmiş ve ölümün failin eseri olarak isnat edilemeyeceği ileri sürülmüştür ${ }^{44}$. Bugün modern Ceza Hukuku doktrininde sorunun kast veya taksirle çözümlenmesinden önce bir neticenin meydana gelmesinde etken olan nedenler nedensellik bağı ile tespit edilerek daha sonra hukuksal değerlendirme yapılarak netice kimin eseri ise ona yüklenmesi gerektiği ifade edilmektedir. Failin fiilinin eseri olmayan neticeler ona yüklenmemelidir. Fiilin

41 Mitsch, s. 54.

42 Verilen diğer bir örnekte bir kimsenin başka bir kimseyi yaklaşan fırtınada yıldırım çarpması ümidiyle ormana göndermesi ve mağdurun gerçekten de yıldırım çarpması sonucu ölmesidir. Burada eski görüş cezanın adil olması için kastın yokluğunu ileri sürüyordu ve kasten öldürmeden ceza verilmemesi gerektiğini belirtiyordu. Çünkü bir ümidin, dileğin gerçekleşmesi söz konusudur. Ancak burada failin öldürmeye yönelik kastı söz konusu olup, cezalandırmamanın nedeni olayın gerçekleşmesindeki tesadüftür. Saf tesadüfle ölüme neden olma Ceza Hukuku anlamında öldürme olarak kabul edilemez ve failin kastı öldürmeye yönelik olsa da tamamen tesadüfi sonuçlara bağlı olduğundan kastı da öldürme kastı olmayıp tamamen cezasız şeye yöneliktir: Roxin, § 11, kn. 44.

43 Objektif isnadiyetin ilk temelleri Hegel tarafından atılmış, daha sonraları Honig tarafından geliştirilmiştir (Ünver, s. 223). Yazara göre şart teorisine göre nedenselliğin tespiti yapılmalı, ancak sorumluluk için sadece nedenselliğin tespiti yeterli olmamakta ayrıca hareketin failine objektif olarak isnat edilebilmesi de gerekir. Şartlar eşit olmakla birlikte hukuksal değerlendirme ile şartlar arasında tercih yapılması da gerekmektedir. Yani hangi şart veya şartların sorumluluğa yol açacağı objektif isnadiyetle belirlenmektedir (Honig, s. 171, 172, $180 \mathrm{vd}$.) Honig tarafından geliştirilen bu teori daha sonraları da tartışılmış ve 60'lı yıllardan itibaren ağırlık kazanmıştır. Ancak henüz tamamlanmadığı (Jescheck, s. 257), sonuçlarının birçok yönden kesin olmadığ da (Roxin, § 11, kn. 46) ifade edilmektedir.

44 Bkz; Roxin, § 11, kn. 44, 45.

Ankara Hacı Bayram Veli Üniversitesi Hukuk Fakültesi Dergisi C. XXIV, Y. 2020, Sa. 4285 
objektif isnadiyetinden sonra, failin sorumluluğu için ayrıca değerlendirilmesi gereken unsurların varlığı tespit edilerek cezalandırma gerçekleştirilmektedir. Dolayısıyla sübjektif isnadiyeti oluşturan kast ve taksir objektif isnadiyetin yapılmasından sonra değerlendirilecek unsurlar olarak anlaşılmaktadır ${ }^{45}$.

Neticeli suçlarda ve dolayısıyla da öldürme suçunda neticenin meydana gelmesinde birçok hareketin rol oynaması nedensellik bağı konusunda farklı teorilerin ortaya çıkmasını sonuçlamıştır ${ }^{46}$. Bu konuda şart teorisi, uygun sebep teorisi, etkin sebep teorisi, önem teorisi, insani sebep teorisi gibi birçok teori doktrinde ifade edilmiştir. Hukukumuzda 5237 sayılı Kanunun yürürlüğe girmesinden ve objektif sorumluluğun kabul edilmemesinden sonra genel olarak şart teorisinin benimsendiği söylenebiliri ${ }^{47}$. Yargitay da artık kararlarında şart teorisini uygulamaktadır ${ }^{48}$. Öldürme suçunda da şart teorisine göre nedensellik bağı kurulduktan sonra objektif isnadiyetin yapılması

45 İsnadiyet hem objektif isnadiyeti hem de sübjektif isnadiyeti içine alan bir kavramdır. Sübjektif isnadiyet faille fiil arasındaki manevi bağ için kullanılırken, objektif isnadiyet fiil ile netice arasındaki bağı tamamlayan tamamen objektif olarak yapılan değerlendirmeyi ifade etmektedir. Nedenselik ve isnadiyet için bkz.: Kelsen, s. 221 vd.

46 Nedensellik bağıyla ilgili olarak ortaya çıkan bu görüşlerin uzun bir geçmişi bulunmamaktadır. Roma, Kilise, eski İtalyan ve Cermen hukuklarında nedensellik bağı sorununa rastlanmamaktadır. Buna karşın müşterek hukukta gözleme dayalı değerlendirmelerde bulunulmuşsa da temeli Avusturyalı hukukçu Julius Glaser tarafından atılan daha sonra Alman İmparatorluk Yüksek Mahkemesi üyesi von Buri tarafından geliştirilen şart teorisi ceza hukukunda ifade edilmeye başlamıştır: Roxin, § 11, kn 8; Önder, , C. II-III, s. 92, 93. Daha sonra von Bar ve Binding adlı yazarlar tarafından genişletilen teori Alman İmparatorluk Mahkemesi tarafından kabul edilmiş ve günümüzde de Alman Federal Yüksek Mahkemesi tarafindan uygulanmaktadır: Ünver, s. 238.

47 Centel/Zafer/Çakmut, Türk Ceza Hukuku, 287; Öztürk/Erdem, s. 230; Hakeri, Ceza Hukuku, s. 189, 190; Hakeri, Nedensellik Bağı, s. 109; Mahmutoğlu/Karadeniz, s. 422, 424; Koca/Üzülmez, Genel Hükümler, s. 131; Zafer, s. 262; Artuk/Gökcen, Özel Hükümler, s. 51; Demirbaş, s. 261. Soyaslan ise etkin sebep teorisini kabul etmektedir: Soyaslan, Ceza Hukuku, s. 363. İnsani (beşeri) sebep teorisi: Hafizoğulları/Özen, Genel Hükümler, s. 209; Toroslu, s. 143 vd. 765 sayılı Kanun döneminde ise görüşler farklı teorilerde dağılmış durumdayd1. Karma uygunluk teorisi: Dönmezer/Erman, C. I, (1997), s. 515 vd.; İçel, s. 169; Alacakaptan, Suçun Unsurları, s. 74. Uygun sebep teorisi: Yüce, s. 229. Şart teorisi: Ünver, s. 253 vd.; Kunter, s. 179 vd.; Önder, C. II-III, s. 101 (sübjektif sorumlulukta). İnsani (beşeri) sebep teorisi: Erem/Danışman/Artuk, s. $281 \mathrm{vd}$.

48 Yargitay Ceza Genel Kurulu kararına göre, “Günümüz modern ceza hukuku anlayışında nedensellik bağının belirlenmiş olması tek başına failin cezalandırılması için yeterli olmayıp ayrıca gerçekleşen neticenin failin eseri olup olmadığının diğer bir ifadeyle ortaya çıkan neticenin belirli bir kişiye objektif olarak isnadının mümkün olup olmadığının tespit edilmesi de gerekmektedir. Olayda öncelikle şart teorisine göre nedensellik bağı ortaya konulmalı, sonrasında gerçekleşen neticenin faile isnat edilip edilemeyeceği araştırılmalıdır”, CGK, 16.05.2017, E. 2017/12-271, K. 2017/278. Ayrica bkz.: CGK, 14.03.2019, E. 2017/269, K. 2019/210; CGK, 02.06.2009, E. 2008/1-186, K. 2009/147. 
gerekir. Yargıtay da, nedensellik bağının belirlenmiş olmasının tek başına failin cezalandırılması için yeterli olmadığını, ayrıca objektif isnadiyetin de yapılması gerektiğini kabul etmektedir. Yargıtay'a göre olayda öncelikle şart teorisine göre nedensellik bağ 1 ortaya konulmalı, sonrasında gerçekleşen neticenin faile isnat edilip edilemeyeceği araştırılmalıdır ${ }^{49}$.

Şart teorisi çerçevesinde iki formül ileri sürülmektedir. Bunlar şartların eşitliği formülü ve kanuna uygun şart formülüdür. Şart teorisi kapsamında şartların eşitliği teorisinin hukukumuzda çoğunlukla kabul edildiği ifade edilmelidir. Her iki teori de nedensellik bağının kesilmesini kabul etmemektedir. Şart teorisine göre nedensellik bağı ya vardır ya yoktur, nedensellik bağının kesilmesinden söz edilemez ${ }^{50}$. Ancak yeni bir nedensellik serisinin ortaya çıtığından söz edilebilir. Bu yeni nedensellik serisi ya failin hareketinin nedenselliğini ortadan kaldırır (ama kesmez) ve tek başına neticeyi meydana getirir veya failin hareketinin nedenselliğine yeni bir nedensellik olarak eklenir ve her ikisi de neticenin meydana gelmesi açısından nedensel değer taşır ya da failin yaptı̆̆ hareketin nedenselliğine herhangi bir etkisi olmaz ${ }^{51}$. Türk doktrininde de çoğunlukla şart teorisi benimsendiğinden nedensellik bağının kesilmesi kabul edilmemektedir. Yargıtayın nedensellik bağının kesildiğini kabul ettiği kararları bulunmaktadır ${ }^{52}$.

49 "Uyuşmazlığa konu somut olayın özellikleri itibarıyla objektif isnadiyet kavramına ayrıca yer verilmesi gerekmektedir. Günümüz modern ceza hukuku anlayışında nedensellik bağının belirlenmiş olması tek başına failin cezalandırılması için yeterli olmayıp ayrıca gerçekleşen neticenin failin eseri olup olmadığının diğer bir ifadeyle ortaya çıkan neticenin belirli bir kişiye objektif olarak isnadının mümkün olup olmadığının tespit edilmesi de gerekmektedir. Olayda öncelikle şart teorisine göre nedensellik bağ 1 ortaya konulmalı, sonrasında gerçekleşen neticenin faile isnat edilip edilemeyeceği araştırılmalıdır. Objektif isnadiyet, neticenin belirli bir insanın eseri olarak görülüp görülemeyeceği anlamına gelmektedir. Ĕger meydana gelen netice, üçüncü kişinin veya bir rastlantının eseri ise faile isnat edilemeyecektir", CGK, 16.05.2017, E. 2017/12-271, K. 2017/278. Ancak Yargitay 16. Ceza Dairesinin Türk Ceza Hukuku uygulamasinda uygun illiyet teorisinin ve bunu esas alan karma uygunluk teorisinin kabul edildiğini belirten kararları bulunmaktadır: 16. CD, 14.07.2017, E. 2017/1443, K. $2017 / 4758$.

50 Önder, Ceza Hukuku Dersleri, s. 196. Ayrıca bkz.: Roxin, § 11, kn. 28. Ancak bazı yazarlar tarafindan kesilen nedensellik kavramı da kullanılmaktadır: Gropp, s. 150, 151.

51 Nedensellik ve nedensellik şekilleri için bkz.: Ünver, s. 241 vd.; Gropp, s. 147 vd; Schönke/ Schröder-Lenckner/Eisele, Vorbem $\S \S 13 \mathrm{ff}, \mathrm{kn} .71 \mathrm{vd}$.

52 CGK, 14.03.2019, E. 2017/269, K. 2019/210; CGK, 02.06.2009, E. 2008/1-186, K. 2009/147. 


\section{b) Objektif İsnadiyet Teorileri}

Nedensellik bağının tespitinden sonra failin öldürme suçundan sorumlu olması için objektif isnadiyetin yapılması gerektiğini belirtmiştik. Objektif isnadiyeti kaldıran birçok kriter bulunmaktadır ${ }^{53}$.

Konumuzla ilgili uygulanması mümkün olan kriterlerden ilki, neticenin normun koruma amacı dışında kalması nedeniyle fiilin objektif isnad edilebilirliğinin ortadan kalkmasıdır. Bu kritere göre, meydana getirilen netice, normun koruma alanı dışındaysa objektif isnadiyet ortadan kalkar. Burada hâkim olan görüşe göre, ihlal edilen normun anlam ve amacına göre gerçekleştirilen neticenin kaçınılması gereken netice olup olmadığı sorulmalıdır. Normun anlam ve amacina göre kaçınılması gerekmeyen, koruma amacı dışında bir netice söz konusuysa isnadiyet ortadan kalkar. Normun anlam ve amacına göre kaçınılması gereken neticeler yasaktır. Örneğin bir park yerinde birlikte oturanlardan $M$, sinirlenerek silahını çeker ve S'ye birkaç el ateş eder. Olayda S yaralanırken, parkta oturan yaşlı bir kadın olan R, aşırı heyecan ve korkudan kalp krizi geçirerek yaşamını yitirir. Olayda M'ye R'nin ölüm sonucu isnat edilemez. Çünkü normun koruma amacı bu tür sonuçları kapsamamaktadır. Tesadüfen gerçekleşen neticeler normun koruma amacı içinde değildir (Atipik olarak ortaya çıkan başka bir olayın neden olduğu neticeden failin sorumlu tutulması düşünülemez). M, S'ye karş1 gerçekleştirdiği öldürme suçu ve genel güvenliğin kasten tehlikeye sokulması suçu bağlamında fikri içtima ilişkisi çerçevesinde sorumlu olacaktır. Failin ihlal ettiği normun riski engelleme amacı bulunmadığ 1 durumlarda, failin fiilinin nedenselliği içinde gerçekleşen neticeler faile objektif olarak isnat edilemez. Örneğin bir kimse tarafından yaralanan (öldürme teşebbüs aşamasında kalmış) mağdurun doktorun tamamen yanlış müdahalesi nedeniyle ölmesi durumunda ölüm ilk hareketi yapana isnat edilemez. Öldürme kastıyla hareket eden kişi öldürmeye teşebbüsten sorumludur. Buna karşın öldürme kastıyla yaralanan kişinin, yarasının enfeksiyon kapması sonucunda ölmesi durumunda isnadiyet söz konusu olup, kişi öldürme suçundan sorumlu olacaktır ${ }^{54}$.

İkincisi, hukuken önemli herhangi bir tehlikenin yaratılmaması nedeniyle fiilin objektif isnad edilebilirliğinin kalkması kriteridir.

$\mathrm{Bu}$ kritere göre, failin hareketi suçun konusu açısından hukuken önemli bir tehlike yaratmamışsa, neticenin faile isnadiyeti ortadan kalkar.

\footnotetext{
53 Ayrıntılı bilgi için bkz.: Akbulut, Ceza Hukuku, s. 343 vd.

54 Jescheck, Lehrbuch, s. 259.
} 
İsnadiyetin kalktığı bu durumda fail riski azaltmadığ 1 gibi arttırmamaktadır $\mathrm{da}^{55}$. Failin hareketi normal yaşam risklerinin doğmasını gerektiriyorsa ve bu yaşam riski ortaya çıkmışsa neticenin isnadiyeti ortadan kalkar ${ }^{56}$. Netice, insanın hükmedebileceği alanın dışında kalıyorsa hukuken önemli olan bir tehlike ya da risk bulunmamaktadır ${ }^{57}$. Hükmedilebilirlik, neticenin önemli oranda idare edilebilirliği ve öngörülebilirliği anlamına gelmektedir. Failin neticeye hükmedilebilmesi objektif isnadiyeti ilgilendirmektedir. Fail tehlike veya risk yaratsa bile, olay tamamen hayatın olağan akışının ve genel hayat tecrübelerinin dışında kalması nedeniyle beklenebilir değilse, netice faile yüklenemeyecektir ${ }^{58}$. Tesadüfen gerçekleşen sonuçlar faile onun eseri gibi isnat edilemez. Bu gibi olaylarda şart teorisi anlamında nedensellik bağı varsa da sonuç failin eseri değildir. Dolaysıyla bir kimsenin başka bir kimseyi yaklaşan firtınada yıldırım çarpması ümidiyle ormana göndermesi ve mağdurun gerçekten de yıldırım çarpması sonucu ölmesi durumunda ölüm sonucu kişiye isnad edilemeyecektir. Çünkü bir ümidin, dileğin gerçekleşmesi söz konusudur. Tesadüfen gerçekleşen, kişinin hükmedilebirliği dışında kalan bu netice kişiye isnad edilemez. Burada failin öldürmeye yönelik kastı söz konusu olsa da cezalandırmamanın nedeni olayın gerçekleşmesindeki tesadüftür. Saf tesadüfle ölüme neden olma Ceza Hukuku anlamında öldürme olarak kabul edilemez ve failin kastı öldürmeye yönelik olsa da tamamen tesadüfi sonuçlara bağlı olduğundan kastı da öldürme kastı olarak nitlendirilemez ${ }^{59}$.

Üçüncüsü, izin verilmeyen riskin gerçekleştirilmesine rağmen, neticenin failin fiilinin etkisiyle gerçekleşmemesi kriteridir. Fail, yaptığ hareketle kişinin hayatı açısından tehlike yaratmakla beraber, ortaya çıkan ölüm neticesi bu tehlikenin sonucu olarak değil de tesadüfen failin fiili ile bağlantı içinde gerçekleşmişse neticenin faile objektif isnadiyeti ortadan kalkmaktadır. Bir başka ifadeyle failin hareketi netice bakımından elverişli tehlike yaratmadığı için netice faile isnat edilemez. Örneğin öldürme kastıyla fail tarafından ateş edilen kişinin hastanede çıkan yangında ölmesi veya hastaneye getirilen kişiye doktorun kasten müdahale etmemesi ve hastanın

\footnotetext{
55 Gropp, Strafrecht, s. 157; Roxin, Strafrecht, s. 377

56 Bohnert, OWİG, § 1, kn. 17.

57 Yargitay meydana gelen bir olayda sorunu hükmedilebilirlikle çözmüşse de, burada uygulanması gereken kriterin bir kimsenin isteyerek kendini zarar veya tehlikeye sokmasının etkisi kriteri olduğunu düşünüyoruz. Bkz.: 70. dipnot.

${ }^{58}$ CGK, 16.05.2017, E. 2017/12-271, K. 2017/278; CGK, 14.03.2019, E. 2017/269, K. 2019/210.

59 Roxin, § 11, kn. 44.
}

Ankara Hacı Bayram Veli Üniversitesi Hukuk Fakültesi Dergisi C. XXIV, Y. 2020, Sa. 4289 
başka hastaneye götürülürken yolda trafik kazası sonucu ölmesi gibi olaylarda ölüm neticesi faile isnad edilemeyecektir. Fail öldürmeye teşebbüsten sorumlu olacaktır. Doktrinde nedensellik bağındaki önemsiz sapmalar diye isimlendirilen (biz objektif isnadiyet sorunu olduğunu kabul ediyoruz) olaylarda sonucun faile isnat edileceği belirtilmektedir. Örneğin öldürülmek için köprüden aşağıya atılan kişinin daha önce köprünün demirlerine çarparak ölse bile fail öldürmeden sorumludur ${ }^{60}$. Keza öldürülmek amacı ile başına baltayla vurulan ancak ölmeyen, daha sonra baltanın açtı̆̆ yaraların enfeksiyon kapması sonucu ölen kişi açısından da netice failin fiilinin eseri olduğu için faile isnat edilmelidir. Ya da öldürmek için hareket edilen ancak ölmeyen kişinin var olan hastalığının tetiklenmesi sonucunda ölmesi durumunda fail öldürmeden sorumlu olacaktır. Mağdurda var olan özel bir durumun failin kastettiği neticeyi gerçekleştirmesi durumunda fail öldürmeden sorumlu olacaktır.

İzin verilmeyen riskin neticede gerçekleştirilmemesi, buna karşılık başka bir kişinin fiiliyle neticenin meydana geldiği olaylarda da netice ilk hareketi yapana objektif olarak isnad edilememektedir ${ }^{61}$. A tarafından öldürülmek kastıyla yaralanan ve hastaneye kaldırılan hastaya hastanede zararlı sonucun ortadan kaldırılması için bir şey yapılmaması, ancak hastanın düşmanı hemşire tarafından öldürülmesi durumunda A öldürmeye teşebbüsten sorumlu olacak, öldürmeden cezalandırılmayacaktır. Hemşire ise öldürmeden sorumlu olacaktır. Müdahale etmeyen doktorsa ihmali suçlarda teşebbüsün kabul edilip edilmemesine göre öldürmeden sorumlu olacak veya olmayacaktır. Buna karşılık izin verilmeyen riskin neticede gerçekleşmesinde failin davranışı varsa neticenin faile isnad edilmesi gerektiği kabul edilmektedir. Failin bir neticeyi gerçekleştirmek için hareket etmesi ve istediği neticenin gerçekleştiği zannıyla ikinci hareketi yapması ve istediği neticenin bu ikinci hareketle gerçekleştiği olaylarda da objektif isnadiyet söz konusu olur ve fail neticeden sorumlu tutulur. Failin öldürmek için ateş ettiği ancak ölmeyen mağduru öldüğü zannılla gömmesi ve mağdurun gömülme nedeniyle ölmesi bu duruma örnek olarak verilebilir. Burada ölüm, failin öngördügünün dışında ama yine kendi hareketinden kaynaklanan nedenden kaynaklanmaktadır. Ölüm ikinci hareketten kaynaklanmakta ama fail bunu bilmemekte, birinci hareketten ölümün gerçekleştiğini zannetmektedir. Ancak bu olayda çözümün nasıl olacağ 1 doktrinde tartışmalıdır. Bir görüş, failin birinci hareketi açısından öldürmeye

\footnotetext{
60 Roxin, § 11, kn. 69, 70.

${ }^{61}$ Roxin, $\S 11$, kn. 73.
}

290 Ankara Hacı Bayram Veli Üniversitesi Hukuk Fakültesi Dergisi C. XXIV, Y. 2020, Sa. 4 
teşebbüsün ikinci hareketi yönünden ise taksirle öldürmenin söz konusu olduğunu ve fiil tekliği veya fiil çokluğu çerçevesinde sorumlu tutulması gerektiğini kabul etmektedir ${ }^{62}$. Diğer görüş ise (çoğunluk görüşü) eskiden dolus generalis ${ }^{63}$ olarak ifade edilen bu durumu sapma çerçevesinde çözüme kavuşturmaktadırlar ve failin öldürmeden sorumlu olacağını kabul etmektedirler. Burada sapmanın önemsiz olduğu belirtilerek failin öldürmeden sorumlu olacağı ifade edilmektedir. Çünkü genel yaşam tecrübesine göre nedensel akış öngörülebilir nitelikte bulunmaktadır ${ }^{64}$. Yukarıda da belirtildiği gibi bu olayda da objektif isnadiyetten hareket edilmesi gerekmektedir. Failin ilk hareketinden ortaya çıkan tehlike somut neticede bizzat fail tarafından gerçekleştirilmiştir. Fail kasten öldürmeden sorumlu tutulmalıdır. Bu tür olaylarda fail bizzat ikinci hareketi fiilinin tamamlanmasının aracı yapmaktadır ${ }^{65}$. Yine öldürmek kastıyla hareket eden failin mağdurun öldüğünü düşünerek olay yerinden ayrılmas1 ve durumu arkadaşına anlatarak cesedi kaldırmasını istemesi, arkadaşının da bunun üzerine mağduru gömerek havasızlıktan ölmesine neden olması halinde sorun yine objektif isnadiyetle çözülmektedir. Öldürme kastıyla hareket eden kişi kasten öldürmeden (TCK m. 281'den şahsi cezasızlık nedeniyle sorumlu tutulamayacak), arkadaşı ise taksirle öldürme ve TCK m. 281 gerçekleştirmiş olacak, ancak fikri içtima kuralları uygulanacaktır ${ }^{66}$.

Dördüncüsü, bir kimsenin isteyerek kendini zarara veya tehlikeye sokmasının etkisi kriteridir. Bir kimsenin kendi isteği ile zarar veya tehlikeye katılması ve bunun sonucunda zarar görmesi durumlarında gerçekleşen netice buna katılan diğer kişiye isnat edilmemektedir. Mağdurun kendi isteği ile kendini bizzat tehlikeye soktuğu durumlarda netice bir başkasına isnat edilmemektedir. Örneğin eroin sahibi olan A, şırıngası olmadığ 1 için B'den şırınga temin eder. B, A'ya dozuna dikkat etmesi uyarısında bulunsa da A eroini dozunu ayarlamadan kendine şırınga eder ve ölür ${ }^{67}$. Her ne kadar B'nin eylemi A'nın ölümü açısından nedenselse de ölüm sonucu B'ye isnat edilemez ${ }^{68}$. Çünkü A bilinçli olarak riski üstlendiği için B'ye ölümün isnat edilebilirliği ortadan kalkmaktadır. Yine uyuşturucu kullanan kişinin

\footnotetext{
62 Bu görüş için bkz.: Tröndle/Fischer, $§ 16$, kn. 7 b.

63 Türk hukukunda Weber kastı olarak ifade edilmektedir. Önder, C. II-III, s. 277.

${ }^{64}$ Schönke/Schröder-Cramer/Sternberg-Lieben, § 15, kn. 58; Gropp, s. 165.

65 Jescheck/Weigend, s. 314, 315.

66 Özgenç, Türk Ceza Hukuku, s. 207, 208.

67 BGH 32, 262, Gropp, s. 158, 159.

68 Gropp, s. 159.
} 
uyuşturucu satıcısından aldığı uyuşturucuyu aşırı dozda kullanıp ölmesinde bu sonuç satıcıya isnad edilmeyecektir. Buna karş1lık uyuşturucu madde bağımlısı olduğu bilinen kişiye fazla miktarda uyuşturucu madde satılması ve bu kişinin yüksek dozda uyuşturucu madde kullanması ve ölmesi olayında ölüm sonucu satıcı kişiye isnad edilecektir ${ }^{69}$. Meydana gelen bir olayda Yargıtay olayı bu kriterle değil hükmedilebirlik çözmüştür ${ }^{70}$.

${ }^{69}$ Olası kastla gerçekleştirilmiş öldürme suçunun gerçekleştiği belirtilmektedir: Özgenç, Türk Ceza Hukuku, s. 203.

70 "Hükmedilebilirlik, neticenin önemli derecede idare edilebilirliği anlamına gelmekte olup gerçekleştirilen fiil, hukuken önemli bir tehlike ya da risk oluştursa bile, olayın tamamen hayatın olağan akışının ve genel hayat tecrübelerinin dışarısında kalması nedeniyle beklenebilir değilse, netice faile yüklenemeyecektir. Kişinin nedensellik bağının üzerinde hâkimiyetinin bulunmaması objektif isnadiyetin yokluğu anlamına gelir. Objektif isnadiyetin varlığı için tipik neticenin fail tarafindan oluşturulan risk nedeniyle meydana gelmesi gerekir. Neticenin, failin meydana getirdiği riskin dışında başka bir risk nedeniyle gerçekleşmesi hâlinde bu netice objektif olarak faile isnat edilemez. Ancak fiilin, suçun konusuna yönelik hukuken izin verilen riski aşan bir tehlike oluşturması ve neticenin bu fiil sonucunda meydana gelmesi durumunda objektif isnat edilebilirlik söz konusu olacak diğer bir deyişle fail tipe uygun neticeye sebebiyet veren hukuken önemli bir tehlike ya da risk oluşturmuş ise netice faile yüklenebilecektir. Gerçekleşen netice, failin hareketi ile tesadüfen birleşen başka sebeplerden meydana gelmişse, bu durumda neticenin faile isnat edilmesi söz konusu olmayacaktır. Bunun gibi sonradan işlenen fiilin daha önceden gerçekleştirilmiş fiilin neticeye ulaşmasını engellemesi hâlinde de önceki fiili gerçekleştiren faile neticenin isnat edilmesi mümkün bulunmayacaktır... Sanık ...'1n sevk ve idaresindeki 50 ..... plaka sayılı gri renkli otomobil ile ön yolcu koltuğunda katılan ... olduğu hâlde, 11.07.2010 tarihinde saat 13.30 sıralarında, meskûn mahalde, kuru zeminli, asfalt kaplamalı, 7 metre genişliğinde, 2 şeritli, seyir istikametine göre aşağı doğru eğimli ve sola hafif virajlı, yol șerit çizgileri mevcut, hız limiti 50 $\mathrm{km} / \mathrm{saat}$ olan ve yaklaşı $300-400$ metrelik görüş mesafesi bulunan bölünmüş devlet yolunda seyrettiği sırada, sanık ...'ın da sevk ve idaresindeki 50 .. 122 plaka sayılı beyaz renkli otomobil ile aynı istikamette seyrettiği, sanık ...'in önünde yolun sağ şeridinde seyreden tanık ...'in sevk ve idaresindeki kamyonu sollayıp geçmesinden hemen sonra sanık ...'ın aynı kamyona arkadan çarpması neticesinde meydana gelen trafik kazasında katılan ...'ün organlarından birinin işlevinin yitirilmesine neden olacak şekilde yaralandığı, mahkemece yapılan keşif sonucu düzenlenen 04.10.2012 tarihli raporda sanık ...'1n 2918 Sayılı Kanun'un 84. maddesinde asli kusurlardan sayılan "arkadan çarpma" hâlinden ve aracın hızını yol, hava ve trafik durumunun gerektirdiği şartlara uydurmamak suretiyle aynı Kanun'un 52/1b maddesini ihlal etmesinden dolayı kazada tam ve asli kusurlu olduğu, tanık ... ile sanık ...'yle yarış yaptığı belirtilen sanık ...' in kusurunun bulunmadığı, Adli Tıp Kurumu Trafik İhtisas Dairesince düzenlenen 24.12.2012 tarihli raporda 04.12.2012 tarihli raporda taraflara atfedilen kusur durumuna ilişkin görüşün olayın oluşuna uygun ve isabetli olduğu belirtilerek sanık ...'ın önünde seyreden kamyona aşırı hızlı bir şekilde ve kontrolsüzce yaklaşarak arkadan çarptığı, dikkat ve özen yükümlülüğüne aykırı hareketi ile olaya sebebiyet verdiği, asli derecede ve tam kusurlu olduğu, kamyon sürücüsü ...'in kurallara uygun seyretmesinden dolay1, sevk ve idaresindeki otomobil ile sol șeritte seyreden sanık ...'in ise meydana gelen olayda etken bir davranışının bulunmaması nedeniyle kusursuz oldukları yönünde görüş bildirildiği anlaşılan olayda; tanık ...'in sanık ...'nin kullandığg gri renkli otomobil ile sanık ...'in kullandığı beyaz renkli otomobilin yarış yaparcasına cadde üzerinden hızlı bir şekilde yan yana gittikleri, gri renkli aracın beyaz renkli aracı sollamak istediği sırada beyaz renkli 
Herhangi bir fiilden zarar gören kişinin yapılacak yardımları riskin tam bilincinde olarak reddetmesi durumunda da gerçekleşen netice daha önce zarar veren davranışı yapan kişiye isnat edilemez. A, B'yi öldürmek için hareket eder, ölmeyen B hastaneye kaldırılır, ancak dini veya mezhebi nedenlerle kan nakline izin vermez ve ölür. A yalnızca öldürmeye teşebbüsten sorumludur. İsnadiyet için kendi davranışıyla zarar gören kişinin karar verme yeteneğine sahip olup olmadığ 1 araştırılmaktadır ${ }^{71}$. Yine örneğin hobi bahçesi sahibi ve bu işi tutkulu olarak yapan A, çevresine sıklıkla inandırıcı bir biçimde hayatının eseri olarak gördüğ̈̈ bahçesine bir şey olması halinde hayatının anlamının kalmayacağını ve intihar edeceğini söyler. A'ya katlanamayan ve

aracın gri renkli araca yol vermediği yönündeki anlatımları, kamyon sürücüsü tanık ...'in olay esnasında aynadan arkadan gelen trafiği kontrol ettiğinde beyaz renkli otomobil ile gri renkli aracın yan yana çok süratli bir şekilde yarış yaparcasına geldikleri, beyaz renkli aracın aşırı derecede hızı bir şekilde kendisini sollamasından 2 saniye sonra gri renkli aracın kullandığ1 kamyonun sol arka kısmına çarptığı yönündeki beyanları, olay esnasında sanık ...'in kullandığı aracın ön yolcu koltuğunda bulunan tanık...'ın kolluk aşamasındaki sanık ...'nin kullandığı araçla karşılaşıp o aracı geçtiklerine ve hızlarının yaklaşık 110-120 km/saat olduğuna dair beyanları, sanık ...' in olay günü sanayi sitesi çıkışında arkadaşı olan sanık ... ile karşılaşıp konuştuktan sonra, önce kendisinin arkasından da ...'nin hareket ettiği, kendisinin hızının yaklaşık 110-120 km/saat olduğu, tanık ...'in kullandığg kamyonu solladıktan sonra arkalarından bir toz bulutu yükseldiğine dair savunmaları birlikte değerlendirildiğinde, sanık ... ile sanık ...'nin meskûn mahaldeki yolda sevk ve idarelerindeki otomobiller ile yarış hâlinde oldukları, sol şeritte seyreden sanık ...'in kendisini geçmek isteyen sanık ...'ye yol vermediği ve geçmesine müsaade etmediği, sanık ...'in yasal hız sınırlarının üzerinde bir hızla seyredip aracının hızını yol ve trafik durumunun gerektirdiği şartlara uydurmamak suretiyle Karayolları Trafik Yönetmeliği'nin 100. maddesinde belirlenen yasal hız sınırlarını ihlal ettiği ve 2918 Sayılı Kanun'un 52. maddesinin birinci fikrasının ( b ) bendinde öngörülen yükümlülüklerini yerine getirmediği sabit olup bu şekildeki hareketlerinin TCK'nın 179/2. maddesinde düzenlenen trafik güvenliğini tehlikeye sokma suçunu oluşturma ihtimali bulunmakta ise de sol şeritte yaklaşı 110-120 km/saat hızla seyreden sanığın kendisini geçmek isteyen diğer sanık ...'ye yol vermek amacıyla sağ şeride geçmesi hâlinde önünde yaklaşık $30 \mathrm{~km} / \mathrm{saat}$ hızla seyreden tanık ... idaresindeki kamyona kendisinin çarpması tehlikesinin bulunması karşısında, sanık ...'ten diğer sanık ...'ye yol vermesinin beklenemeyeceği, kendisiyle yarış hâlinde olan sanık ...'nin önünde seyreden kamyona arkadan çarpması şeklinde gerçekleşen neticenin sanık ...'in hükmedebileceği alanın dışında kaldığı, sanığın dikkat ve özen yükümlülüğünü yerine getirmiş olması durumunda diğer sanık ...'nin yaptığı kazanın kesinlikle meydana gelmeyeceğinin, olayın sanığın yasal hız sınırlarının üzerinde seyretmek suretiyle oluşturduğu risk nedeniyle meydana geldiğinin ve gerçekleşen neticenin sanığın eseri olduğunun söylenemeyeceği, dolayısıyla katılanın organlarından birinin işlevinin yitirilmesine neden olacak şekilde yaralanmasıyla sonuçlanan trafik kazasının objektif olarak sanığa isnat edilemeyeceği, buna bağlı olarak sanığın meydana gelen olayda kusurunun bulunmadığı kabul edilmelidir”, CGK, 14.03.2019, E. 2017/269, K. 2019/210.

${ }^{71}$ Roxin, § 11, kn. 111.

Ankara Hacı Bayram Veli Üniversitesi Hukuk Fakültesi Dergisi C. XXIV, Y. 2020, Sa. 4293 
ondan kurtulmak isteyen B, A'nın bahçesini darmadağın eder. Bunu gören A gerçekten de intihar eder ve ölür. A sorumluluğunun bilincinde olarak isteyerek zarar veya tehlikeye girdiğinden B kasten öldürme suçundan sorumlu olmaz ${ }^{72}$. B'nin davranışı hukuken önemli tehlike oluşturmadığından ve gerçekleşen netice intihar eden kişinin iradesine bağlı olduğundan ölüm sonucu B'ye isnad edilebilir nitelikte değildir.

Belirtilmesi gereken diğer bir durumda mağdurun bizzat kendisi değil de üçüncü kişinin mağduru rızasıyla tehlikeye sokması halidir. Bu gibi durumlarda mağdurun isteği bile olsa tehlike mağdurun birlikte etkisiyle değil de bizzat 3. kişi tarafindan yaratıldığından netice bu kişiye isnat edilecektir. A'nın kendi isteği ile B'nin şırınga ettiği eroinin etkisi ile ölmesi olayında B ölüm neticesinden sorumludur ${ }^{73}$. İstek üzerine öldürmelerde de ölümü gerçekleştiren kişi sorumludur.

Beşincisi yabancı tehlikenin bilinçli olarak üstlenilmesi kriteridir. Burada bir kimse bizzat tehlike yaratmamakta, başkası tarafından yaratılan riskin bilinci içinde tehlikeye girmektedir ${ }^{74}$. Örneğin bir doktor hastaneye gelen riskli bir hastaya kendisini hastanede tedavi edemeyeceğini, zira sahip olduğu imkânların onun sağlığının korunması açısından yeterli olmadığını söyler. Ancak hasta başka bir hastaneye gitmeyi kabul etmez. Bunun üzerine doktor elindeki imkânlarla acil durumdaki hastanın sağllğı açısından gerekenleri yapar, ancak hasta ölür. Bu netice doktora isnat edilemez. Ancak hastanın ölümünde doktorun dikkat ve özen kurallarına aykırılığı söz konusu olsaydı, bu sonuç doktora isnat edilebilecekti. Bunun dişında imkânları olmadığ kabul etmiş ve hasta ölmüşse bu netice kendisine isnat edilecektir. Ölümün gerçekleşmesi muhtemelse olası kastla öldürme suçu söz konusu olacaktır. Mağdurun kendisini bizzat tehlikeye sokan davranışı ile mağdurun isteği ile bir başkasının mağduru tehlikeye soktuğu durum birbirinden ayrılmalıdır ${ }^{75}$. Mağdurun tehlikeli davranışın gerçekleşmesinde bizzat katkısı varsa ve bunu üçüncü bir kişiyle birlikte aynı anda bilinçli olarak gerçekleştirmişse 3 . kişiye bu netice isnat edilemez. Bir başkasıyla aids virüsü taşıdı̆̆ını bilerek birlikte olan ve virüs bulaşan ve ölen kişi açısından aids virüsünü taşıyan

\footnotetext{
72 Heinrich, s. 159.

73 Özbek/Doğan/Bacaksız, Genel Hükümler, s. 245.

74 Roxin, § 11, kn. 121.

75 Özbek, s. 445.
} 
kişinin sorumluluğu söz konusu değildir ${ }^{76}$.

Altıncısı izin verilen risk kriteridir. İzin verilen riskin kasıtlı suçlarda uygulanması noktasında tartı̧̧ma omakla beraber kabul edildiği söylenebilir ${ }^{77}$. Toplumsal gelişmeyi sağlamak ve çok gerekli hukuki değerlere ulaşmak için daha az öneme sahip hukuki değer ihlali riskleri göze alınmakta ve yapıları gereği tehlikeli nitelik taşıyan bazı faaliyetler için hukuken izin verilen risk alanları oluşturulmaktadır. Bu alanın içinde kalındıkça yapılan harekete ve onun neticesine izin verilmektedir ${ }^{78}$. Yapılan davranış izin verilen risk kapsamında kalmak şartıyla fail tarafindan yaratılan netice faile objektif olarak isnat edilemeyecektir ${ }^{79}$. Eğer fail tarafından yaratılan risk, izin verilmeyen risk kapsamındaysa o netice faile objektif olarak isnat edilecektir. İzin verilen risk kapsamına trafik, fabrikalar, patlayıcı madde imalatı, maden ocağ1 işletmeleri, spor faaliyetleri, tıbbi müdahaleler vb. girmektedir ${ }^{80}$. Örneğin bir hekim tıbbi müdahalenin hukuka uygunluğu içinde hareket etmesine rağmen risk kapsamındaki ölüm neticesi meydana gelmişse bu netice izin verilen risk içinde değerlendirilmeli ve doktora isnat edilmemelidir ${ }^{81}$. Bu anlamda bir doktorun tedavi amacıyla yaptığı ameliyat neticesinde kurallara riayet etmesine rağmen ölüm meydana geldiğinde, ölüm sonucu doktora objektif olarak isnat edilemez. Tıbbi müdahale hastanın rızasıyla yapılmışsa

76 Roxin, § 11, kn. 133.

77 Roxin, s. 382, 383.

78 Ünver, s. 258, 259. Ayrıca bkz.: İçel, s. 144, 145.

79 İzin verilen riskle ilgili olarak Türk hukukundaki görüşler için bkz.: İçel, s. 146; Bayraktar, s. 100-103; Bafra, s. 120.

80 İçel, s. 145.

81 Yargitay Ceza Genel Kurulu da konuya ilişkin verdiği kararda tıbbi müdahalelerin izin verilen risk kapsamında olduğunu belirtmiştir. Yargıtay’a göre, "Tibbi müdahaleler genel olarak "izin verilen risk" kapsamında gerçekleştirilen müdahalelerdir. İzin verilen risk, hukuken müsaade edilen tehlike oluşturma alanı olarak tarif edilmektedir. Kişiler zarar ya da tehlike doğuracak bütün davranışlarında cezalandırılma tehdidi altında bulunmamalıdır. Toplumsal gelişmeyi sağlamak veya daha kıymetli hukuki değerlere ulaşabilmek için bazı durumlarda kişilere yaptıkları ișin niteliği gereği belirli oran ve ölçüde risk oluşturması için izin verilmelidir. Önemli olan belirlenen kurallara uygun şekilde gerçekleştirilen davranışların izin verilen risk alanı içinde yapılması ve neticenin de bu alan içinde gerçekleştirilmiş olmasıdır. $\mathrm{Bu}$ takdirde sorumluluk söz konusu olmayacaktır... Ancak konunun uzmanı olmayan doktorun teşhis veya tedaviyi üstlenmesi anlamında üstlenme kusuru ve gerek doktorun bireysel olarak gerekse çalıştığı kurum yönünden kurumsal olarak organizasyon kusurunun, izin verilen risk dışında kaldığını söylemek mümkündür”, CGK, 16.05.2017, E. 2017/12-271, K. $2017 / 278$. 
da aynı kişi ölümüne rıza göstermemekte ${ }^{82}$, bilakis sağlığına kavuşma arzusu taşımaktadır. Buradaki ölüm, hukuka uygunluk nedeni olan rıza kapsamında olmayıp, izin verilen risk çerçevesinde olduğundan doktora isnad edilemeyecektir. Tedavi amacıyla aydınlatılmış rızayla hastaya verilecek ilacın hastanın ömrünü kısaltma ihtimalinin olduğu ve kısalttığ1 durumda, ölüm sonucu izin verilen risk içinde olduğundan doktora isnad edilemeyecektir. Keza müdahalenin zorunlu olarak doğurduğu neticeler dışındaki neticeler için de aynı şey geçerlidir. Dolayısıyla tıbbi müdahale için verilen rıza, doktorun fiiliyle neden olduğu neticeyi (ölümü) hukuka uygun hale getirmemektedir. Ancak ölüm, izin verilen risk alanı içinde bulunduğundan doktor bundan sorumlu tutulmamaktadır ${ }^{83}$. Buna karşın aynı neticeye, çok daha az tehlikeli müdahale ile ulaşılabilecekse doktorun fiili, izin verilen riskin dışındadır.

Sonuncusu ise, başka birinin sorumluluk alanına geçen neticelerin isnadiyeti (yabancı birinin sorumluluk alanına dâhil etme) kriteridir. $\mathrm{Bu}$ kriterde, isnadiyetin ortadan kalkmasının nedeni, belirli tehlike kaynaklarının gözetlenmesi ve ortadan kaldırılmasına ilişkin olarak belirli meslekleri icra eden kimselerin, kendi sorumluluk alanında gerçekleşen olaylardan sorumlu olmalarıdır. Bunun önemi olaya sebep olan kişilerin, meslek sahibinin davranışının ortaya çıkardığı sonuçtan sorumlu tutulmamalarıdır. Örneğin hırsızı kovalayan polisin bu esnada kaza yaparak ölmesi durumunda ölüm olayı hırsıza isnad edilemez. Aksi durumda kovalanan hırsızın polise teslim olmak zorunda olduğu sonucunu ortaya çıar. Böyle bir yükümlülük de kişinin kendisinin cezalandırılmasına katkı sağlamak anlamı taşır ve genel hukuk prensiplerine aykırıdır ${ }^{84}$ (AY m. 38).

Bu kapsamda en zor ve açılığa kavuşturulamayan olay grubu herhangi biri tarafından öldürme kastıyla yaralanan kimsenin doktor hatası nedeniyle ölmesidir. Yaygın görüş basit ve orta nitelikteki meslek hatalarından doğan ölümün veya hastanın çektiği acıların artmasının ilk yaralamaya neden olan kişiye isnat edilmesi gerektiğini ifade etmektedir. Buna karşılık büyük doktor

\footnotetext{
82 Roxin, § 11, kn. 92.

83 Alman hukukunda bu gibi durumlar izin verilen risk çerçevesinde nitelendirilirken (bkz.: İçel, s. 145, dipnot 48), Türk hukukunda bazı yazarlar tarafından tıbbi müdahalenin hukuka uygunluğundan yola çıkılarak gerçekleşen neticelerin hukuka uygun olduğu ifade edilmektedir: İçel, s. 146; Bayraktar, s. 102, 103; Bafra, s. 119, Özek, s. 166; Dönmezer/Erman, C. II, s. $51 \mathrm{vd}$.

${ }^{84}$ Roxin, § 11, kn. 138, 139, 140.
} 
hataları ise isnat edilmemelidir. İkinci görüşe göre güven esası gereğince pozitif hareket etmek zorunda olan doktorun hatalı davranması durumunda bu netice ilk hareketi yapana isnat edilmemelidir. Ancak doktor mevcut tedavi tedbirlerini kullanmazsa bu takdirde gerçekleşen netice faile isnat edilmelidir. Üçüncü görüşe göre ise doktorun meslek hatasının katkısıyla ortaya çıkan neticede, yaralanmanın, kendisiyle tipik olarak bağlantılı olan riski gerçekleştirip gerçekleştirmediği önemlidir. Bu durumda doktorun büyük hatası olsa bile netice ilk hareketi yapana isnat edilmelidir. Bir başka ifadeyle zararlı sonuç tipik yaralanmanın riski içindeyse bu netice ilk hareketi yapana isnat edilmelidir. Buna karşın doktorun hatalı davranışı narkoz hatalarında olduğu gibi tipik yaralanma riski dışında ise bu netice ilk hareketi yapana isnat edilmemelidir. Bir başka görüş ise doğru olanın bu iki görüşün kombine edilmesi olduğunu söylemektedir. Bunun için doktorun davranışının failin yarattığı tehlikeyi uzaklaştırıp uzaklaştırmadığı veya gerçekleşmesine engel olup olmadığı önemlidir. Eğer mağdur yaralanmadan değil de özellikle doktor hatası nedeniyle eklenen bir tehlikeden ölmüşse, doktor esas riski kendi sorumluluk alanında olan başka bir riskle değiştirmiş olduğundan bu netice faile isnat edilemez. Örneğin ameliyat esnasında kanamaya yol açan yanlış kesim nedeniyle ölüm, narkoz hatası nedeniyle kalp durması (geri dönüşü olmayan) ${ }^{85}$, yanlış tedavi uygulanması gibi olaylar bu şekildedir. Fail yalnızca gerçekleştirdiği kadarıyla, yani kasten öldürmeye teşebbüsten sorumludur. Doktorun hatasının ağır veya hafif olması fark etmez. Doktor ise yaptığ 1 eylemden sorumludur ${ }^{86}$. Doktorun kastının olduğu durumlarda ise neticenin daha önceki yaralamayı gerçekleştiren kişiye isnad edilmesi söz konusu değildir. CGK'na konu olan bir kararda, "Sanık H....S....' in, tabanca ile ateş etmesi sonucunda merminin maktûlün karın üst noktadan girdiği, iç organ, bă̆ırsakları yaraladı̆̆g, maktûlün önce S.... Devlet Hastanesine kaldırıldı̆̆ acilen ameliyata alındığgl, vena mazenterika inferier yırtığl, 7 yerden ince bağırsak parçalanması tespit edilip, bir adet kopma olduğu, acil ameliyatla yırtıkları dikilip tamir edildiği, bu arada maktûle 7 ünite kan verildiği, daha sonra bir müddet hastanede kaldıktan sonra 10.09.1999 tarihinde şifa ile taburcu olduğu, bu suretle öldürme kast ve iradesi ile ateşlenen etkili ve tesirli silahın açttğı yaranın ameliyat ve tedavi nedeniyle öldürücü sonuç ve etkisinin onarıldĭgl, mağdurun daha sonra 25.10.1999 tarihinde açılan davada duruşmaya geldiği, rahat şekilde iddiasinı sergileyip ifadesini verdiği, önce Trabzon'da daha

\footnotetext{
85 Roxin, § 11, kn. 142.

86 Roxin, § 11, kn. 141, 142.
}

Ankara Hacı Bayram Veli Üniversitesi Hukuk Fakültesi Dergisi C. XXIV, Y. 2020, Sa. 4297 
sonra G....H.... intaniye polikliniğine müracaat ettiği, rahatsizlı̆̆ının arttı̆̆l, 02.11.1999'da yoğun bakıma yatırldiğı, 06.11.1999 tarihinde vefat ettiği, ATK 1. İhtisas Kurulunun 26.07.2000 tarih ve 1169 sayll raporuna göre "ölümün ateşli silah yaralanmasının tedavisi için hepatit virüslü kan verilmesi sonucu gelişen akut hepatitten ileri geldiğinin" tespit edildiği, olayda CGK, saniğın, maktûle tabanca ile ateş ederek onu karın bölgesinden yaraladiğl, maktûlün kaldırıldiğ hastanede ameliyat edilerek kurtarıldiğ ve iyileşerek taburcu edildiği, ancak ameliyat sirasinda verilen 7 ünite kandan bir tanesinde bulunan hepatit virüsünün bulaştığl ve ölümün akut hepatit sonucunda meydana geldiği konusunda bir uyuşmazlık ve kuşku bulunmamaktadır. Adli Tıp Kurumu 1. İhtisas Kurulunun konuya ilişkin 26.07.2006 günlü raporunun sonuç kısmında;

"25.08.2005 tarihinde ateşli silahla yaralandı̆̆g, 06.11.2005 tarihinde hastanede akut hepatit tanısi iletedavigörürkenöldügü̈bildirilen 1947 doğumlu S...S... hakkinda düzenlenen adli ve tıbbi belgelerden elde edilen bilgilere göre; 1- Ateşli silahla yaralandiğ l, damar ve barsak yaralanması saptandı $\breve{g}$, ateşli silah yaralanması başlı başına ölüme yol açacak nitelikte olmakla birlikte gerekli cerrahi onarımın gerçekleştirildiği, tedavi sırasında verilen kan ürünlerinin birinde hepatit virüsü saptandiğg; yaralanma ve tedavi sonrast yapılan tıbbi incelemelerde hepatit tanısı konduğu ve kan ürünü verilmesi ile hastalık gelişiminin uyumlu olduğu dikkate alındiğında; ölümün ateşli silah yaralanmasının tedavisi için hepatit virüslü kan verilmesi sonucu gelişen akut hepatitten ileri geldiğinin kabulü gerektiği,

2- Ateşli silah yaralanması ile ölüm arasında illiyet bă̆ bulunduğu, hepatit virüslü kan verilmesi ve hepatit gelişiminin failin iradesi dışında eklenen bir sebep olduğu, kastın tıbben tayin edilemeyeceği" belirtilmiştir. Görüldü̈̆̈̈ gibi, olayda sanı, öldürme kastı ile hareket etmiş ve ölüm neticesi de meydana gelmiştir. Sanığın eylemi ile meydana gelen yara Adli Tip Kurumu raporunda da belirtildiği üzere başlı başına ölüme yol açacak nitelikte olup, bu eyleme bağlı olarak ta ölüm neticesi gerçekleşmiştir. Meydana gelen ölüm neticesi, sanığın eyleminin doğal sonucu olup, sanığın eylemi ile başlattı̆̆ nedenler serisinden bağımsız gelişen bir netice olmadı̆̆ıdan, sanığın eylemi ile ölüm neticesi arasında nedensellik bağl kesilmemiştir. Bu nedenle 5237 sayılı TCK kapsamında, sanığın kasten adam öldürme suçunu işlediğinin kabulünde zorunluluk bulunmakta" şeklinde belirleme yapılmıştır ${ }^{87}$.

${ }^{87}$ CGK, 2.6.2009, E. 2008/1-186, K. 2009/147.

298 Ankara Hacı Bayram Veli Üniversitesi Hukuk Fakültesi Dergisi C. XXIV, Y. 2020, Sa. 4 
Doktrinde bu olayda ölüm sonucunun yaralamayı gerçekleştiren kişiye isnad edilemeyeceği ifade edilmektedir. Zira mağdur hastanede iyileştirilmiş, ölüm verilen virüslü kan nedeniyle gerçekleşmiştir. Nedensellik bağı varsa da objektif isnadiyet söz konusu değildir. Ölüm yaralamanın meydana getirdiği tehlikeye bağlı olarak gerçekleşmemiş, hepatitli kan verilmesi suretiyle meydana gelmiştir. Dolayısıyla da bu görüşe göre Yargıtay'ın görüşü isabetli değildir ${ }^{88}$. Biz Yargıtayın verdiği kararın öldürme kastıyla hareket eden kişi açısından sonuçta doğru olduğunu düşünüyoruz. Zira kişinin sağlık durumuna göre virüsün kuluçka süresi, hastalanma, virüsün çoğalma hızı, ölüme yol açması veya iyileşmesi farklı olmakla beraber olaydaki süreler verilen ortalama sürelere uymamakta ve çok daha hızlı ölümün gerçekleştiği görülmektedir (25.08.1999 tarihinde yaralaniyor, 10.09.1999 taburcu oluyor, 26.10.1999 tarihinde akut hepatit tanısıyla hastaneye yatırılıyor ve tüm tedavilere rağmen 06.11.1999 tarihinde ölüm gerçekleşiyor. Yaralanmadan itibaren iki ay on gün gibi bir sürede ölüm gerçekleşiyor). Yaralanma nedeniyle vücut direncinin düşmesi ve bağışıklığının zayıflaması virüsün çok kısa sürede ölüm sonucunu gerçekleştirmesini sağlamıştır. Olayda yaralanma ve virüslü kan verilmesi birlikte ölümü gerçekleştirmiştir. Virüslü kan verilmesinin yaralamanın riskinin yerine geçtiği söylenemez. Dolayısıyla yaralanmanın etkisinin olmadığını, tamamen virüslü kan verilmesi sonucu ölümün gerçekleştiğini söylemek kanaatimizce doğru değildir. Yargıtayın gerekçesine katılmamakla beraber (nedensellik bağının kesilmediğine ve tamamen yaralamaya bağlı olarak ölümün gerçekleştiğine ilişkin) sonuçta verdiği kararın doğru olduğunu düşünüyoruz. Ayrıca hepatitli kan verilmesinde sorumluluğu olan kişilerin de sorumluluğu yoluna gidilmesi söz konusu olacaktır.

Doktorun yaraya iyi bakmadığı veya gereken tedaviyi yapmadığı için mağdurun yaralanması nedeniyle ölmesi halinde ilk hareketi yapana isnadiyetiyle ilgili iki görüş bulunmaktadır. Bir görüş burada isnadiyeti kabul etmemektedir. Diğer görüş ise yaralamanın ölümcül seyrini durdurmayı başaramayan doktorun davranışı riskin yerini almamışsa ölümden yalnızca doktor sorumlu değildir. İlk hareketi yapan ve doktor ölüm neticesinden kendi kusurları çerçevesinde sorumludurlar. Doktor taksirli öldürmeden sorumludur. İlk hareketi yapan ise kasten öldürmeden sorumludur. Buna karş1lı ölüm sonucu, esas olarak doktorun hatasından kaynaklanıyorsa ölüm ilk hareketi

88 Koca/Üzülmez, Özel Hükümler, s. 81, 82. Aynı yönde Özgenç, Türk Ceza Hukuku, s. 204, 205, dipnot 172 . 
yapana isnat edilemez. Sadece doktor ölümden taksirle sorumludur ${ }^{89}$. Türk hukukunda bazı yazarlarca herhangi bir ayrıma gitmeksizin doktor hatalarından dolayı neticenin gerçekleştiği olaylarda ölüm sonucunun yaralamaya sebebiyet veren kişiye isnad edilemeyeceği, gerçekleştirdiği kadarıyla sorumlu olacağ 1 kabul edilmektedir. Doktorun ise taksirle öldürmeden cezalandırılacağ 1 belirtilmektedir ${ }^{90}$.

Aynı durumun mağdurun taksirli hareketinin söz konusu olduğu olaylar için de geçerli olduğu belirtilmektedir ${ }^{91}$. Eğer meydana gelen neticeler yaralamanın içinde gerçekleşmemişse (mağdurun ilaçları karıştırması gibi), ilk fiili gerçekleştiren neticeden sorumlu değildir. Neticeler sadece mağdurun sorumluluk alanındadır. Meydana gelen ölüm neticesi yaralamanın sonucu olmakla beraber mağdurun yapması gereken davranışı yapmamasına dayanmaktaysa neticenin ilk hareketi yapana isnat edilmemesi gerektiği ifade edilmektedir ${ }^{92}$.

Mağdurun davranışıyla gerçekleșen ölüm sonuçlarında isnadiyet sorunu tartışılmaktadır. Burada failin yaptı̆̆ hareket mağdurun başka türlü davranma imkânını ortadan kaldırmışsa (özgür iradesiyle hareket etmesini engellemişse) ölüm sonucu mağdurun hareketinden meydana gelse bile objektif isnadiyet kabul edilmektedir. Örneğin A'nın, öldürmek kastıyla, B'ye ateş ettiği ancak mağdurun isabet almamak için kaçtığı ve aniden yola çıkarak bir aracın çarparak öldüğü olayda kasten öldürmeden dolayı ceza vermek gerektiği kabul edilmektedir ${ }^{93}$.

\section{B. Manevi Unsur}

Öldürme suçu, kasten işlenebilen bir suçtur. Zaten TCK'nın 81.

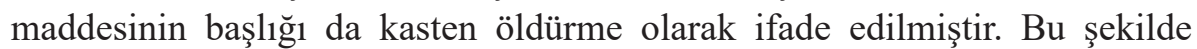
belirleme yapılmasaydı da öldürme suçunun kasten işlenebileceği ifade

\footnotetext{
89 Roxin, § 11, kn. 143.

90 Özgenç, Türk Ceza Hukuku, s. 209-211.

91 Bkz.: Roxin, § 11, kn. 144.

92 Roxin, § 11, kn. 144.

93 Özgenç, Türk Ceza Hukuku, s. 200.
}

300 Ankara Hacı Bayram Veli Üniversitesi Hukuk Fakültesi Dergisi C. XXIV, Y. 2020, Sa. 4 


\section{edilecekti (TCK m. 21). Doğrudan kastla ${ }^{94}$ veya olası kastla ${ }^{95}$ işlenmesi}

94 “...doğurduğu bebeği sahiplenmek istemeyip sosyal hizmetlere vermeyi düşünen sanı̆̆ın, bebekten kurtulma amacını taşıması, bu düşünceyle hareket eden sanığın, savunma sistemi son derece zayıf olan 5 günlük bebeğini, kış mevsiminde, her türlü yabani hayvan sald1rısına açık, yakın çevrede yerleşim yeri bulunmayan ormanlık alanda, moloz yığınlarının yakınına bırakıp ayrılması karşısında; yaklaşık 24 saat tek başına, ormanlık alanda kalan bebeğin açlık, donma veya yabani hayvan saldırısı gibi nedenlerden biriyle öleceği mutlak bir durumdur. Kaçınılmaz netice olan ölümün soğukta kalma sonucu gerçekleştiği de göz önüne alındığında, istemediği bebekten bir şekilde kurtulmak isteyen sanığın, ölümle sonuçlanacağını bildiği hâlde isteyerek yaptığı eylemini doğrudan kasıtla gerçekleştirdiği kabul edilmelidir", CGK, 28.05.2020, E. 2020/1-164, K. 2020/239

95 “Sanık Ramazan Altıntaş'ın 09.04.2016 tarihinde saat 20.00 sıralarında sevk ve idaresindeki 06 ZBM 63 plaka sayılı kapalı kasa kamyonet cinsindeki araç ile yanında bulunan akrabası ve arkadaşı olan tanıklar Hakan Ceylan ve Levent Yıldırım ile birlikte Ankara Kalesi'ne giderek viski içtikleri, sanığın ayrıca enerji içeceği de içtiği, saat 22.00 sıralarında yine sanığın sevk ve idaresindeki aynı araç ile Gölbaşı ilçesine gidip bir süre dolaştıktan sonra evlerine dönmek üzere tekrar yola çıktıkları, Konya Yolu üzerinde Gölbaşı istikametinden şehir merkezine doğru yerleşim yeri merkezinde, aydınlatmanın olduğu, görüşe engel bir durumun bulunmadığı, azami hız sınırının otomobiller için 82, kamyonet cinsi araçlar için $70 \mathrm{~km} /$ saat olduğu, dört şeritli, düz, kuru ve asfalt yolda seyir hâlinde olan sanığın, saat 23.47 sıralarında Dikmen Caddesi istikametine doğru sola dönüşün olduğu 1şıklı kavşağa geldiğinde kırmızı ışık ihlali yaparak o esnada boş olan en sol şeritten hızlı bir şekilde geçmeye çalıştığ sırada, karşı yoldan gelen ve kendisine yanan yeşil ışıkla birlikte Dikmen Caddesine geçmek için sola dönüş yapan sürücü Gözde Çiçek'in sevk ve idaresindeki 06 BL 6993 plaka sayılı otomobilin sağ yan tarafına çarptığı, çarpışmanın etkisiyle her iki aracın da savrulduğu ve sürücü Gözde Çiçek'in aracının 25,7 metre ileride durduğu, saat 00.57 'de onaylanan rapora göre sanığın 2,46 promil alkollü olduğu, araçta sıkışan sürücü Gözde Çiçek'in olay yerine gelen itfaiye ekiplerinin müdahalesiyle araçtan çıkartılarak ambulansla hastaneye kaldırıldığı ancak araç içi trafik kazası sonucu olușan kafa ve genel beden travması ile buna bağl1 olarak gelişen hemopnömotoraks sonucu vefat ettiği olayda; daha önce 1,00 promilin üzerinde alkollü araç kullandığg gerekçesiyle trafik güvenliğini tehlikeye sokma suçundan hakkında hükmün açıklanmasının geri bırakılması kararı bulunan ve alkollü araç kullanması nedeniyle sürücü belgesi iptal edilen sanık Ramazan Altıntaş'ın, olay tarihinde de sürücü belgesi alkol sebebiyle iptal edilmiş olmasına rağmen sevk ve idaresindeki kamyonet cinsi araçla trafiğe çıktığı, sanığın kaza anında emniyetli sürüş yeteneğini olumsuz olarak etkileyecek ölçüde alkollü olduğu, sanığın kazadan hemen önce yolda bir iki aracı makas atarak geçtiği, 1şıklı kavşağa yaklaştığı sırada hızını azaltmadığı gibi kendisine kırmızı 1şık yanmasına rağmen durmayarak kavşaktan hızlı bir șekilde geçtiği, bu suretle kazanın oluşumunda asli ve tam kusurlu olduğu, başka bir kimsenin kusurunun olmadığ 1 hususunda tereddüt bulunmamaktadır. Yerleşim yerinde bulunan ve gece vakti de olsa yoğun bir trafik akışı olan ışıklı kavşağa yaklaşan sanığın, kendisine kırmızı 1şık yanması ve önündeki araçların durduğunu görmesine rağmen karşı istikametten gelip Dikmen Caddesine gitmek için sola dönüş yapacak araçların önüne çıkabileceğini öngördüğü hâlde hızlı bir şekilde o esnada boş olan en sol şeritten geçmesi ve muhtemel olan neticenin meydana gelmesi suretiyle o sırada Dikmen Caddesine geçmek için yeşil 1şıkla birlikte sola dönüş yapan sürücü Gözde Çiçek'in sevk ve idaresindeki araca çarparak Gözde Çiçek'in ölümüne neden olması, kaza tespit tutanağ 1 ve tanık ifadelerine göre fren yapmadığ 1 ve hızını azaltmadığ 1 sabit olan sanığın, öngördüğü muhtemel neticeyi engelleme çabasının ya da neticeyi göze almadığına dair bir davranışının bulunmaması, başka bir ifadeyle gerçekleşen muhtemel neticeye kayıtsız kalarak kabullenmesi, ayrıca somut olayın kanun koyucu tarafindan ola- 
mümkündür. Şiddet içeren oldukça tehlikeli hareketlerde ölüm neticesi çok yakın bir ihtimalse ve ancak şans eseri gerçekleşecek bir tesadüfle ölüm meydana gelmeyecekse, olası kastın bulunduğu kabul edilmektedir ${ }^{96}$. Ölümün gerçekleşmesi ihtimalinin olasılık değeri arttıkça, failin neticeyi istemediği iddiası zayıflamakta ${ }^{97}$, dolayısıyla olası kastın varlığı benimsenmektedir. Ancak bu belirleme tek başına yeterli olmayıp, olaydaki tüm objektif ve sübjektif olgular ile failin lehine ve aleyhine durumlar ile birlikte değerlendirilerek karar verilmelidir ${ }^{98}$. Yargıtayın da kararlarında objektif ve sübjektif unsurları değerlendirdiği, tehlikeli hareketlerde ölüm neticesinin çok yakın ihtimal dahilinde olduğu hallerde olası kastı kabul ettiği söylenebilir ${ }^{99}$.

Suçun temel şeklinde diğer sübjektif unsurlara ilişkin belirleme yapılmamıştır. Dolayısıyla suçun hangi saikle işlendiği temel suç tipinin oluşması açısından önemsizdir. Ancak suçun nitelikli şeklinde failin kan

s1 kastın düzenlendiği madde gerekçesinde belirtilen örnek olaydaki gibi gerçekleştiğinin anlaşılması karşısında sanığın eyleminin olası kastla öldürme suçunu oluşturduğu kabul edilmelidir", CGK, 02.07.2019, E. 2019/1-121, K. 2019/518;“sanığın kullandığı yaklaşık 6-7 metre boyunda, 2-3 metre eninde, tekne adı yazmayan seri numarası ACN 097370100 olan 150 BHP gücünde, "evinrude " marka dıştan takma motora sahip beyaz renkli, 5 ya da 6 kişi kapasitesi olan fiber tekne ile yabancı uyruklu şahısları Ildırı ve Karareis civarından aldığı, seyir sırasında teknenin kapasitesinin üzerinde insan taşıması ve olumsuz hava koşulları nedeniyle teknenin su aldığı, motorunun stop etmesi neticesinde alabora olduğu, teknede bulunan 9 kişinin sağ kurtarıldığı, 5'i çocuk 2'si kadın olmak üzere 7 yabancı uyruklu göçmenin ise suda boğularak öldüğü, teknenin alabora olması sırasında sanı̆̆ın tekneden atlayarak yüzmek suretiyle en yakın karaya ulaştığı, olaya müdahale eden görevli tanıkların ölenlerde can yeleğinin olmadığını; sağ kurtulan göçmenlerin ise soruşturma aşamasında verdikleri ifadelerde sanığın seyir sırasında can yeleğini giymelerine izin vermediğini, geminin batması üzerine can yeleklerini giydiklerini beyan ettikleri olayda; muhtemel tüm sonuçları öngörmesine rağmen öngördüğü sonucu kabullenerek yani olursa olsun diyerek fiili icra ettiği anlaşıldığından, sanık hakkında olası kastla öldürme suçundan dolayı mahkumiyet kararı verilmesi gerekirken, suç vasfından yanılgıya düşülerek, sanıkların bilinçli taksirle öldürme suçundan dolayı yazılı şekilde cezalandırılmalarına karar verilmesi”, 12. CD, 23.09.2019, E. 2019/10783, K. 2019/9244.

Bkz.: Hakeri, Ceza Hukuku, s. 240, 241.

97 Heinrich, I, s. 193, 194.

98 Bkz.: Hakeri, Ceza Hukuku, s. 241.

99 “...sanığın tabancasını doldur boşalt yaptığı, daha sonra şarjörünü çıkardığı, sanığın tabancanın içerisinde mermi kalmadığ 1 düşüncesiyle hareket ederek tetiğe bastığ 1 ve tabancanın bu şekilde ateşlenmesi sonucu maktule isabet eden mermi çekirdeğinin ölüme neden olduğu" olayda Yargitay olası kastı kabul etmiştir: 1. CD, 10.09.2019, E. 2019/1948, K. 2019/3653. Yargıtay bir kararında da yere çömelip tabancasını dizine dayayarak havaya doğru ateş ettiği ve bu suretle arkadaşı olan kişinin öldüğü olayda olası kastı kabul etmiştir: 1. CD, 08.10.2019, E. 2019/1785, K. 2019/4171. Ayrica bkz.: 12. CD, 23.09.2019, E. 2019/10783, K. 2019/9244. 
gütme saikiyle, töre saikiyle, bir suçu gizlemek, delillerini ortadan kaldırmak veya işlenmesini kolaylaştırmak ya da yakalanmamak amacıyla işlenmesi cezanın daha fazla verilmesini gerektiren neden olarak kabul edilmiştir.

Kast için suçun kanuni tanımında yer alan unsurların bilinmesi gerekir. Dolayısıyla öldürdügü kişinin insan olduğunu bilmesi gerekir. Yaptığı fiilden kişinin öleceğini veya ölebileceğini bilmelidir. Hata durumunda TCK m. 30/1 uygulanır. Örneğin ateş ettiği şeyin insan olduğunu gören kişi kasten hareket etmiştir. Ancak ateş ettiği şeyin insan olduğu noktasında bilgi eksikliği varsa, örneğin bir hayvana ateş ettiğini zannediyorsa kastın varlığı söz konusu değildir. Taksirli sorumluluk söz konusu olabilecektir. İnceleme konumuz suçun temel şekli açısından şahısta yanılma önem arzetmez. Nedensellik bağının bilinip bilinmemesi doktrinde tartışmalıdır. Hâkim olan görüş nedenselliğin de bilinmesi gerektiği yönündedir ${ }^{100}$. Yeni düşünce sorunun kast sorunu olmayıp objektif isnadiyetle ilgili olduğunu ifade etmektedir. Eğer gerçekleşen durum neticenin faile onun eseri olarak isnad edilmesini engelliyorsa objektif isnadiyet söz konusu değildir. Kastla ilgili bir sorun mevcut değildir ${ }^{101}$. Burada faile netice isnad edilemeyeceğinden teşebbüsten dolayı sorumluluk tayin edilecektir. Eğer hareket tarafından yaratılan risk, neticede gerçekleştirilmişse netice faile objektif olarak isnad edilecektir ${ }^{102}$. Biz de burada sorunun objektif isnadiyetle ilgili olduğunu kabul ediyoruz. Öldürülmek için köprüden aşağıya atılan kişinin daha önce köprünün demirlerine çarparak ölmesinde netice faile isnad edilecektir. Objektif isnadiyeti kaldıran kriterlerin ise bilinmesi gerekmemektedir. Gerçekleşmişse kişi hakkında uygulanır.

Kasten öldürmek için hareket eden kişinin mağdurun ölmemesi üzerine yardım etmemesi, olay yerinden ayrılması ayrı bir sorumluluk doğurmamaktadır. Ceza hukukunda bir hukuki değer ihlalinin aynı faile bir kez yüklenebileceği kabul edilmektedir. Aksi durmda hareketinden geri dönmeye yönelik hareketleri yapmayan her icrai failin aynı zamanda ihmali fail olarak cezalandırılacağı, bunun da kanunun sistematiği ile uyumlu olmadığı belirtilmektedir. Bir icrai hareketi yapan kişinin daha sonraki yardım etmeme şeklindeki ihmali müstakil cezalandırmaya yol açmamakta, sadece gönüllü vazgeçmeye ilişkin hükümlerin uygulanmamasına neden olmaktadır.

\footnotetext{
100 Türk hukukunda nedensellik bağının bilinmesi gerekmediğine ilişkin olarak bkz.: Centel/ Zafer/Çakmut, Türk Ceza Hukuku, s. 365.

101 Gropp, s. 164.

102 Jescheck/Weigend, s. 312.
} 
Bir başkasını kasten vücut veya yaşamına yönelik bir tehlike durumuna sokan kimse ayrıca ihmalinden dolayı sorumlu olmaz. Dolayısıla TCK m. 83 ve m. 98'den sorumluluk söz konusu olmaz. Kasten öldürme fiilini gerçekleştiren kişi meydana gelen sonuçtan kastı nedeniyle sorumlu olur, ayrıca ihmalinden dolayı sorumlu olmaz. Bir suçtan kişinin iki ayrı sebeple sorumlu tutulması söz konusu değildir. Dolayısıyla kasti bir hareketi, kasti bir ihmalin zamansal olarak takip etmesi halinde icrai hareket ihmali hareketi tüketmektedir. Bu hallerde öngelen tehlikeli eylemden dolayı neticeyi önleme (m. 83) ve yardımın ihmali suçu (m. 98) uygulanmamaktadır ${ }^{103}$. Yargıtay'ın belirlemesi de bu yöndedir ${ }^{104}$.

${ }^{103}$ Geniş bilgi için bkz.: Hakeri, Ceza Hukukunda İhmal Kavramı, s. 305 vd.

104 “Ancak, oluşa ve dosya kapsamına göre, sanığın olay tarihinde mağdurun çalışmış olduğu pazar yerine geldiği, mağdura Mardinli ... tanıyormusun dediği, mağdurun tanıyorum demesi üzerine, mağdurdan kendisini onun yanına götürmesini istediği, mağdurun da işinin olduğunu, götüremeyeceğini söylemesi üzerine, sanığın mağdura "niye götürmüyorsun lan" diyerek saldırdığı, kavga ettikleri, sanığın olay sırasında üzerinde bulunan ancak ele geçirelemeyen biçakla mağdurun göğüs bölgesine bir kez vurarak, mağduru kalbe ve toraksa nafiz olacak şekilde yaraladığı ve olay yerinden kaçtığı, mağdurun almış olduğu darbe sonucu hayati tehlike geçirdiği olayda, hedef alınan vücut bölgesi ve meydana gelen yaralanmalar dikkate alındığında, sanığın eylemi ile ortaya çıkan kastının öldürmeye yönelik olduğu ve bu nedenle 5237 sayılı TCK'nın 81, 35. maddeleri uyarınca kasten öldürme suçuna teşebbüsten cezalandırılmasına karar verilmesi gerektiği düşünülmeden, suç niteliğinde yanılgıya düşülerek yazılı şekilde kasten yaralama suçundan hüküm kurulması; Bozmayı gerektirmiş olup, katılan vekilinin temyiz itirazları bu nedenle yerinde görüldügünden, hükmün tebliğnamedeki düşünceye aykırı olarak (bozulmasına), 20/01/2015 gününde oybirliği ile karar verildi. 1 . cd, 20.1.2015, e. 2013/5572, k. 2015/83; "kasti veya taksirli hareketi ile mağdurun yardıma muhtaç hale gelmesine neden olan kişi, yardım veya bildirim yükümlülüğünün yerine getirilmemesi suçunun faili olamaz. Failin, kendi davranışı ile yardıma muhtaç hale gelen mağdura yardım etmesi ya da durumu ilgili makamlara bildirmesi gerekir ise de, aksi davranışta bulunması halinde yardım veya bildirim yükümlülüğünün yerine getirilmemesi suçu oluşmaz. Bu durumda fail sadece kasten ya da taksirle işlediği suçtan veya koşulları oluştuğu takdirde TCK'nun 83. maddesindeki kasten öldürmenin ihmali davranışla işlenmesi ya da TCK'nun 88. maddesindeki kasten yaralamanın ihmali davranışla işlenmesi suçlarından sorumlu olur. $\mathrm{Bu}$ açıklamalar 1şığında uyuşmazlık konusu değerlendirildiğinde; Ölen ... ile sanık ...'in önceden birbirlerini tanıdıkları, olay akşamı ölenin elinde biralarla gelerek, aracının içerisinde alkol alan sanık ...'den kendisini gezdirmesini istediği, önce tanık Nihat'ın sanık ...'e ait araçla sanığı ve öleni gezdirdiği, bu esnada sanık ... ile ölenin bira içmeye devam ettikleri, daha sonra sanık ...'in önceden tanıdığı inceleme dışı sanık ...'yi telefonla arayarak kendisiyle birlikte olmak istediğini söylediği, tanık Nihat'ın arac1 ....'nin kaldığı otelin yakınlarında durdurup yanlarından ayrıldığı, ölenin ise sanık ...'in yanından ayrılmak istemediği ve ....'yi kendisinin de tanıdığını belirtip beraber gezebileceklerini söylediği, ölenin evine uğrayıp bira için bir miktar daha para aldıkları, daha sonra sanık ...'nin kaldığı otele giderek buradan 5 şişe bira alıp arabaya döndükleri, yanlarına ....'yi de alıp beraber araçla gezmeye başladıkları, bir ara yemek yedikten sonra sanık ...'in kullandığı araç ile tekrar dolaşmaya, araç içerisinde bira içmeye devam ettikleri, .... ile cinsel ilişkiye girme düşüncesinde olan sanık ...'in jandarma veya polis baskınına uğramamak 
Failin kasten yaralamayla hareket ettiği ancak ölümün meydana geldiği hallerde TCK m. 87/4 uygulanacak, kasten öldürme suçu söz konusu olmayacaktır. TCK m. 87'ün uygulanması için yaralamanın basit tıbbi müdahaleyle giderilemeyecek bir yaralama olması gerekmektedir. Yargitay kasten öldürmenin gerçekleşmediğini, kasten yaralamanın varlığını kabul ettiği olaylarda yaralamanın basit tıbbi müdahaleyle giderilemeyecek olduğu ve mağdurda olan bir nedenin eklenmesi sonucunda ölümün meydana geldiği durumlarda m. 87/4'ten hüküm kurmaktadır ${ }^{105}$.

için nispeten tenha bir bölge olan Bulduklu köyü civarındaki sulama kanalı boyunca devam eden toprak yolda ilerlediği ve toprak zeminle aynı seviyeye kadar suyla dolu olan, 4.9 metre derinliğindeki sulama kanalının 2.7 metre kenarına aracını park ettiği, aracın arka koltuğunda oturan ölenin ise uyuyakaldığ 1 , ....'nin aracın arka koltuğunda sanık ...'le cinsel ilişkiye girme düşüncesiyle sanık ...'den öleni kaldırmasını istediği, ölene ismiyle hitap etmesine rağmen ölenden ses gelmeyince sanık ...'in arabanın kanal tarafına bakan arka kapısını açtığı, öleni kolundan tutup dışarıya çıkardığı sırada, gerek alkolün gerekse uyku sersemliğinin etkisi altındaki ölenin kolunu sanığın elinden kurtarmak için hamle yaptığ sırada dengesini kaybederek içi su dolu kanala düşüp çırpınmaya başladığı, sanık ...'in ise ölene seslenip sudan çıkmasını istediği, ölenin akıntıya kapılıp kaybolduğu, olay yerinde bir süre daha bekleyen sanıkların arabayla olay yerinden ayrıldıkları, ilçe merkezine gelirken yolda aracı durdurup cinsel ilişkiye girdikleri, sanık ...'in diğer sanık ...'yi oteline bıraktıktan sonra saat 04.19 'da ilçe jandarma komutanlığına durumu bildirdiği, yaklaşık bir gün sonra bulunan ölenin kanında 1.54 promil alkole rastlandığı ve ölümün suda boğulma sonucu meydana geldiği anlaşılan olayda; sanık ... aracını yolla arasında herhangi bir engel bulunmayan sulama kanalının kenarında durdurduktan sonra, öncesinde birlikte dolaşıp alkol almaları nedeniyle alkolün ve aracın arka koltuğunda uyuyakalması nedeniyle de uykunun etkisi altında olduğunu bildiği ölenin mevcut durumu itibarıyla dengesini sağlayamayıp sulama kanalının içine düşebileceğini ve boğulabileceğini öngörmesi gerekirken, dikkat ve özen yükümlülüğüne aykırı davranarak öleni araçtan çıkarmak suretiyle taksirle hareket etmiş, gerek uyku sersemliğinin gerekse aldığı alkolün etkisi altında olan ölenin dengesini kaybedip sulama kanalına düşmesine ve ölümüne sebebiyet vermiştir. Öte yandan, sanığın öleni kolundan tutup araçtan dışarıya çıkardığı sırada ölenin kolunu sanığın elinden kurtarmak için hamle yapmasıyla nedensellik bağının kesildiğinden de söz edilemez. Zira ölüm olayı, sanığın taksirli hareketleri ile uyku sersemliğinin ve alkolün etkisi altında olan ölenin kolunu sanığın elinden kurtarmak için yaptığı hareketin birleşmesi sonucu meydana gelmiş olup nedensellik bağ ortadan kalkmamıştır. Bu nedenle, yerel mahkemece sanığın taksirle öldürme suçundan cezalandırılmasında bir isabetsizlik bulunmamaktadır. Bu itibarla, Özel Dairenin bozma kararının sanık ... hakkında kurulan hüküm yönünden kaldırılmasına, yerel mahkeme hükmünün katılanlardan sadece Ahmet vekil ile temsil edildiği halde, katılan ... lehine vekalet ücretine hükmolunması yerine, tüm katılanlar lehine vekalet ücretine hükmolunması isabetsizliğinden bozulmasına”, CGK, 17.01.2017, E. 2014/252, K. 2017/5.

105 "Kasten öldürme suçunda; uyuşmazlık; suçun vasıflandırılmasına ilişkindir. Somut olayda, yaşamsal tehlike yaratan isabetin bir adetle sınırlı kalması, diğer yaranın basit tıbbi müdahaleyle giderilebilir nitelikte olması, sanığın daha önceden arkadaşlık yaptığı ve olaydan sonra hastaneden taburcu olan maktûle aynı gün diğer sanıklarla birlikte geçmiş olsun zi- 
Sapma durumunda hedeflenin dışında başka bir kişiye karşı gerçekleştirilen fiillerde bu kişi açısından kast veya taksirine gör belirleme yapılır ve fikri içtima kuralları çerçevesinde sorun çözümlenir. Hedeflenin haksız tahrik altında öldürülmesi için hareket edildiğinde haksız tahrik sadece hedeflenen için uygulanır, sapma sonucunda gerçekleşen fiil açısından haksız tahrik hükmü uygulanmaz. Yargitay'ın kabulü de bu yöndedir. Ancak doktrinde hedeflenin dışındaki kişi açısından da haksız tahrikin uygulanacağını kabul eden yazarlar bulunmaktadır. 765 sayılı Kanun döneminde de bu görüş çerçevesinde belirleme yapilmaktayd $1^{106}$.

Kastın kanuni tanımda yer alan hangi haksızlığa yönelik olduğunun tespit edilmesi gerekir. Çünkü somut olayda kişi öldürme kastıyla da hareket edebilir, yaralama kastıyla da hareket edebilir. Örneğin kişinin ölmediği durumlarda yaralamadan mı sorumluluk tayin edileceğinin, yoksa öldürmeye teşebbüsten mi sorumluluk tayin edileceğinin belirlenmesi gerekmektedir. Yine ölümün meydana geldiği olaylarda kasten yaralamadan mı ölümün meydana geldiğinin yoksa öldürme fiilinin mi söz konusu olduğunun tespit edilmesi gerekir $^{107}$. Kast hukuki bir konu olması nedeniyle ispata ihtiyaç göstermemekle

yaretine gitmesi, hava karardıktan sonra çıkan tartışma sebebiyle aniden gelişen ve hedef seçme olanağı da bulunmayan kavganın hareketli ortamında, aralarında öldürmeyi gerektirecek derecede önceye dayalı husumetleri olmayan maktul boğuşurken, yaralayan sanığın eylemini gerçekleştirirken öldürme kastıyla hareket etmediğinin kabulü gerekir. Yaralanan maktulün kendisinde mevcut kronik kalp hastalığının aktif duruma geçmesinden gelişen bir myokard infarktüsü neticesi ölmesiyle sonuçlanan olayda, yaralama kastıyla gerçekleştirilen eylemle ölüm sonucu arasında nedensellik bağı da bulunduğundan, sanık hakkında 5237 Sayılı T.C.K.nın 87/4. maddesi uyarınca hüküm kurulması yerindedir. Bu nedenlerle, sanıklar öldürme kastıyla hareket etmediklerinden, sanığın eyleminin kasten yaralama sonucunda ölüme sebep olma olarak kabulünde zorunluluk bulunmaktadır”, CGK, 27.12.2011, E. 2011/1-151, K. 2011/290.

106 Tezcan/Erdem/Önok, s. 185.

107 "sanığın arkadaşları olan tanıklar a ve o ile evinin önünde gece saat 01.30 sularında sohbet ederken, alkolü olan maktü-lün, yanında tanık h ile olay yerine geldiği ve sanığ“ bir durum mu var” dediği, sanığın ise bir durum olmadığını, evinin önünde oturduğunu söylemesi üzerine maktülün“ dağılın evinize" dediği, çıkan tartışmada maktülün sanığa hakaret ederek yumruk attığı, sanığın da yumruk vurması neticesinde alkollü olan maktülün yere düşerek kafasını asfalt zemine çarptığı, kafatasında oksipital sağ yandan kaideye uzanan $12 \mathrm{~cm}$ kırık oluşarak beyinde meydana gelen subdoral ve subaraknoidal kanama sonucu beyin kontüzyonundan öldüğü tüm dosya kapsamından anlaşılmakla; sanığın eyleminin 765 sayılı TCK nun 452/1 maddesinde tanımlanan katil kastıyla olmayan darp neticesinde öldürme suçunu oluşturduğundan, lehe yasanın belirlenmesi bağlamın- da 5237 sayılı TCK. nun 87. maddesinin 4. fikrasının ilk cümlesi ile TCK . nun Yürürlük ve Uygulama Şekli Hakkındaki Kanu- nun 9.maddesi gereğince somut karşılaştırma yapılarak lehe olan yasanın belirlenmesi gerekirken yazılı şekilde hüküm kurulması, bozmayı gerektirmiştir”, 1. CD, 2007, E. 2006/2117, K. 2007/2790. 
birlikte, somut olayda failin ceza sorumluğunu etkileyen şartların varlığıyla ilgili maddi olaylar ispata ihtiyaç gösterirler. Dolayısıyla da kastın tanımlanması ispat konusu değilse de somut olayda failin kastının öldürmeye mi yoksa yaralamaya $\mathrm{m} 1$ yönelik olduğunun ispatlanması gerekir. Bir başka ifadeyle kastın kanuni tanımda yer alan hangi haksızlığa yönelik olduğu ispat sorunu olarak karşımıza çıkmaktadır ${ }^{108}$. Kastın tipikliğin sübjektif unsuruyla ilgili olması, iç olay, ruhsal durumla ilgili bulunması, fail ile işlediği fiil arasındaki manevi bağ 1 ifade etmesi nedeniyle tespiti zorluk göstermektedir. Ancak şu belirtilmelidir ki, failin kastının hangi suça yönelik olduğu somut olayın şartları göz önünde tutularak belirlenmelidir ${ }^{109}$. Yargıtay belirlemelerde bazı ölçütler kullanmaktadır ${ }^{110}$ : Suç nedeni, mağdur ile fail arasında husumet

\footnotetext{
${ }^{108}$ Sözüer, s. 168.
}

109 Erem, s. 298 vd. Yargıtay’’n bu konudaki ölçütleri için bkz.: Sözüer, s. 169 vd. "Oluşa ve dosya kapsamına, özellikle tanıklar göre; sanık ... ile maktul ... arasında olaydan yaklaşık bir yıl kadar önce gönül ilişkisi yaşandığı, ancak sanık ...'nın başka birisiyle evli olması nedeniyle ilişkiye devam etmek istemeyerek maktulden ayrılmak istediğini söylemesi üzerine, maktulün sanık ... ve ailesinin adres ve telefon bilgilerini internette uygunsuz sitelerde paylaştığı, sanık ...'nın birlikte yaşadığ ${ }_{1}$ ailesinin evine sıklıkla pasta, çiçek, tesisatçı ve saire göndererek uzun süre rahatsız ettiği, olay günü yine sanık ...'nın annesi Se.nın, kızı Ye.yi arayarak maktulün evlerine çiçek ve doğalgazcı gönderdiğini söylemesi üzerine sanık ...'nın babası ..., kardeşi sanık ..., dayıları olan sanıklar ..., ..., ... ve ile dayılarının işçileri ve arkadaşları olan sanıklar ..., ..., ... ile Ye.nin akrabası sanık ...'in bu hususu konuşmak üzere bir araya geldikleri, sanık ... aracılığıyla maktul ... Sa.nı olay yerine çağırdıkları, sanık ...'nın önden bir taksi ile olay yerine gittiği, arkadan diğer araçlarla sanıkların yanlarına sopalar, av tüfekleri ve sanık ...'in de ruhsatsız tabancasını alarak fikir ve eylem birliği içerisinde olay yerine gittikleri, burada maktulü görerek önce aracına saldırdıkları, maktulün kaçmaya çalışması üzerine arkasından av tüfeği ile ateş edildiği, ancak isabet etmediği, sanıkların birlikte hareket ederek maktulü kovaladıkları ve sopalarla darp ettikleri, bu sırada sanık ...'in tabanca ile maktulün çeşitli yerlerine ateş ettiği ve hep beraber olay yerinden araçlarına binerek uzaklaştıkları anlaşılan olayda; Sanıkların fikir ve eylem birliği içerisinde hareket ederek öldürme fiili üzerinde ortak hakimiyet kurdukları, olay yerine giderken yanlarına av tüfekleri almış olmaları nazara alındığında kastlarının öldürmeye yönelik olduğunun anlaş1ldığ1, bu itibarla kasten öldürme suçuna TCK'nin 37/1. maddesi kapsamında katıldıkları ve fail olarak sorumlu tutularak anilan Kanun maddesi delaletiyle TCK'nin $\underline{81}$. maddesi uyarınca cezalandırılmaları gerektiği gözetilmeden, yanılgılı değerlendirme sonucu yazılı şekilde kasten yaralama suçlarından hükümler kurulması", 1. CD, 22.1.2020, E. 2019/1872, K. 2020/206.

${ }^{110}$ Bu ölçütler hakkında bkz.: Artuk/Gökcen, Özel Hükümler, s. 57 vd.; Gökcen/Balcı, (2013), s. $37 \mathrm{vd}$. 
bulunup bulunmad $1 \mathrm{~g}_{1}{ }^{111}$, husumetin nedeni ve derecesi ${ }^{112}$ engel bir durum nedeniyle eylemine devam edip etmediğ $i^{113}$, isabet alınan bölge (hayati tehlike oluşturup oluşturmadığ , hayati bölgeye isabet edip etmediği $)^{114}$, hedef seçme

111 “Nuri’nin, sanığın üzerinde bulunan mağduru tutup kaldırma biçiminde gerçekleşen müdahalesinin "engel neden" sayılamayacağı, mağdurla arasında ciddi bir husumet tespit edilemeyen sanığın tek bıçak darbesini vurduktan sonra, eylemini sürdürmek istediğini gösteren herhangi bir delilin bulunmadığ 1 ve olayda o sırada edinilen kesici kısmı $10 \mathrm{~cm}$ uzunluğundaki bıçağın kullanılmış olması hususları bir bütün olarak değerlendirildiğinde; itiş-kakış ortamında mağdurun sol göğüs bölgesine vurularak hayati tehlike geçirecek düzeyde yaralanmasına yol açan bir bıçak darbesi tek başına öldürme kastının bulunduğunu göstermeyeceğinden, yaralama kastıyla hareket e dildiğinin kabulünde zorunluluk vardır", CGK. 31.3.2009,2008/1-248-2009/ 82.

112 CGK, 12.03.2020, E. 2016/1-797, K. 2020/175.

113 "Sanık ve katılan arasında, olay öncesinde iki kez yumruklaşmaya varan kavga yaşanmış olması ve sanığın olay öncesinde bu nedenle katılanı aradığı, kaçamaklı savunmasında da belirttiği üzere karşılaştıklarında, 20-25 metre mesafeden 3 el ateş ettiği anlaşılmaktadır. Sanık, silahını kolluk görevlilerine boş olarak teslim etmiştir. Bütün bu hususlar nazara alındığında, sanık ve katılan arasında olay öncesinde kavgaya varan husumet bulunduğu, mağdura, elverişli vasıta niteliğindeki $9 \mathrm{~mm}$ 'lik tabanca ile yine sonuç almaya elverişli mesafeden, hayati bölge niteliğindeki batın bölgesine yönelik olarak ateş ettiği, 3 el ateş ettikten sonra silahında mermi kalmadığı ve mağdurun yaralandığını gördükten sonra herhangi bir müdahalede bulunmadan ya da yardım istemeden olay yerinden ayrıldığ 1 sabit olup, sanığın öldürme kastı ile hareket ettiğinin kabulünde zorunluluk bulunmaktadır; zira sanık, önceden aralarında bulunan husumet nedeniyle elverişli mesafeden, elverişli bir silah ile mağdurun hayati bölgelerini hedef seçerek, birden fazla kez ateş etmiş, mağdurun, bu atışlardan bir tanesinin isabet etmesi nedeniyle yaralanması üzerine ve silahında merminin bitmesi nedeniyle eylemine devam edememiş, onu olay yerinde bırakarak ayrılmıștır. $\mathrm{Bu}$ nedenle sanığın, sabit olan eylemine uyan, kasten öldürmeye kalkışma suçundan cezaland1rılmasına karar verilmesi yerine, dosyadaki kanıtlara uymayan bir șekilde kasten yaralama suçundan cezalandırılmasına karar verilmesi isabetsizdir.”, CGK, 02.03.2010, E. 2009/1252 , K. 2010/46.

114 "Sanıkların olay tarihinden önce maktul ve mağdurun ikamet etmekte olduğu mahallede bir kavgaya karıștıkları, olayın yargıya intikal ettiği ve ilgililer hakkında kamu davası açıldığı, ancak yerel mahkemece getirtilip incelenen evraklara göre mağdur ve maktulün bu olayla herhangi bir ilgilerinin bulunmadığı, olay gecesi sanıkların, tanıklarla birlikte bir aracın içinde alkol almakta olan mağdur ve maktulü gördükleri ve önceki olayı bahane ederek mağdur ve maktule sataştıkları, tanıkların ve kolluğun müdahalesi üzerine olayın büyümesinin önlendiği, aynı gece aradan kısa süre geçtikten sonra sanıkların, yeniden maktul, mağdur ve tanıkların bulundukları yere geldikleri, sanık Fatih Kılıç'ın ele geçirilemeyen, ancak sanık savunmaları ve tanık beyanları doğrultusunda yerel mahkemece odun olduğu ve silahtan sayıldığı kabul edilen sopayla önce maktulün kafasının arka bölgesine vurarak maktulü yere düşürdüğü, daha sonra da aynı sopayla maktulün kardeşi olan katılanın kafasına vurduğu, diğer sanıkların da aynı nitelikteki sopalarla mağdurun kafasına ve vücudunun çeşitli yerlerine vurdukları, mağdur ve maktulün yere düşmesi üzerine olay yerinden ayrıldıkları, tanıkların, mağdur ve maktulü evlerine götürdükleri, mağdur ve maktulün ertesi gün ailesi tarafından hastaneye kaldırıldıkları, maktulün olaydan on yedi gün sonra öldüğü, ölü muayene ve otopsi ile adli raporlar doğrultusunda, maktulün künt kafa travması sonucu öldüğü, kafatası iç yüzeyinde oksipital kemik orta hattan sol arka fosaysa ve oradan foramen 
imkanının bulunup bulunmadı ${ }_{1}{ }^{115}$, darbenin şiddeti ve meydana getirdiği

magnuma uzanan ve çevresinde sonlanan kırık hattı görüldüğ̈ ve sanığın eylemi ile ölüm arasında illiyet bağı bulunduğu, mağdurun ise kafasına aldığ 1 darbe sonucu hayati tehlike geçirecek ve vücudunda yaşam fonksiyonlarını ikinci derecede etkileyecek nitelikte kemik kırılmasına neden olacak şekilde yaralandığı sabit olup, sanıkların ilk tartışma olayının polislerce yatıştırılmasından kısa süre sonra, olay yerinden uzaklaşmak yerine, olayda kullanılan ve öldürücü nitelikte olduklarında kuşku bulunmayan sopalarla inşaat alanı olan, yakınında yerleşim yeri olmayan ve mağdur ile maktulün yardım istemelerine olanak bulunmayan olay mahalline gelmeleri, mağdur ve maktule vurarak yere düşürmeleri, yerde de vurmaya devam etmeleri, akabinde de olay yerinden kaçmaları, hedef alman vücut bölgeleri, kullandıkları vasıta ve yaralanmaların nitelikleri ile darbelerin şiddeti birlikte değerlendirildiğinde, sanık Fatih Kılıç'ın maktule yönelik eyleminin kasten öldürme, her üç sanığın katılana yönelik eylemlerinin de kasten öldürme suçuna teşebbüsü oluşturduğunun kabulü gerekir. Bu itibarla, Özel Daire bozma kararı yerinde olup, yerel mahkeme direnme hükmünün suç niteliğinin yanılgılı belirlenmesi isabetsizliğinden bozulmasına karar verilmelidir.", CGK. 18.09.2012, 2012/1- 941-2012/1780; "Oluşa ve delillere göre,sanığın hamile olduğunu bildiği eşinin batın bölgesine bıçağını sokarak hayati tehlikeye maruz kılıp,20 gün iş ve gücüne engel olacak şekilde yarala- dığı olayda,suçta kullanılan aletin niteliği,hedef alınan vücut bölgesi,meydana gelen yaranın niteliği dikkate alındığında öldürme kastıyla hareket edildiği anlaşıldığı halde,öldürmeye teşebbüs yerine yaralama suçundan hüküm kurulması", 1. CD, 27.12.2006, E. 2005/4813, K. 2006/6045.

115 "Geceleyin, kavganın hareketli ortamında, rastgele salladığı tek bıçak darbesi ile mağduru iç organ yaralanmasına neden olmayacak biçimde yaralayan sanığın hayati bölgeleri özellikle seçtiğine ve eylemini sürdürmesine mani bir hal bulunduğuna dair kanıt da mevcut olmadığına göre, olayda yaralama kastı ile hareket ettiğinin kabulü gerekmektedir”, CGK, 08.07.2008, E. 2008/1-88, K. 2008/184. 


\section{yaralanmanınmahiyeti ${ }^{116}$, suçta kullanılan silahın (aracın) niteliği ${ }^{117}$, kullanılış}

116 "Sanığın mağdur katılanı bıçak ile batın sol alt kadranda yaklaşık $1 \mathrm{~cm}$. genişliğinde ve 10 $\mathrm{cm}$ derinliğinde, sol meme üst kısmında yüzeysel kesi oluşturacak şekilde, büyük damar ve iç organ lezyonuna ve yaşamsal tehlikeye yol açmaksızın, basit tıbbi müdahale ile giderilemeyecek şekilde yaraladığı olayda; mağdur katılanın sol göğsünden yüzeysel kesi oluşacak şekilde yaralanmasının kavganın hareketli ortamında mazur görülebilir olması ve yara yerinin, özellikle öldürücü bölgenin hedef alındığını göstermemesi, sanık ile mağdur katılan arasında daha öncesine dayanan ve öldürmeye gerektiren bir husumetin bulunmaması, san1ğın eylemine engel hal olmaksızın son vermesi ve yaralanmanın mağdur katılanın yaşamını tehlikeye sokmaması karşısında, sanık hakkında silahla kasten yaralamak suçundan TCK m.86/1, 3-e uyarınca hüküm kurulması yerine, yazılı şekilde kasten insan öldürmeye teşebbüs suçundan hüküm kurulması" hususunu hukuka aykırı olarak nitelendirmiştir.”, 1. CD, 09.12.2011, E. 2011/4961, K. 2011/7639; “Sanı̆̆ın önceden tanımadığ1 ve olay nedeniyle tartışıp kavgaya tutuştuğunun olayı haber alarak kavga mahalline gelen oğlu katılanla arasında öldürmeyi gerektirecek herhangi bir husumet bulunmamas1, darbedilen sanığın kalabalık kavga ortamında taşıma ruhsatlı silahı çıkarıp 5-6 metre mesafeden yaptığı atış sırasında bilinçli olarak katılanın yaşamsal bölgesini hedef aldığı konusunda kesin bir belirlemenin yapılamaması, sanığın tartışmaya başladığı ve kavgaya tutuştuğu kişi olan şahsı yaralama kastıyla bacağına sadece bir el ateş ettiği göz önünde alındığında olay yerine sonradan gelen şahsın oğlu katılana yönelik öldürme kastı taşıdığının kabulünün makul olmaması, katılanda meydana gelen $2 \times 2 \mathrm{~cm}$ ebadındaki sıyrığın basit bir tıbbi müdahale ile giderilebilecek ölçüde hafif nitelikte olması, tanık olarak dinlenen şahsın Mahkemede sanığın olay sırasında katılanı hedef alarak ateş etmediği, sanığın ateş etmeyi kendi iradesi ile sonlandırdıktan sonra sanığın kolunu tutarak olay yerinden uzaklaştırdığı yönündeki beyanı, silahının şarjöründe sekiz adet dolu fişek olduğu hâlde sanığın, katılana yönelik tek atış yaptıktan sonra inceleme dışı katılanın bacağını hedefleyerek yine tek atış yapmakla yetindikten sonra ciddi bir engel olmaksızın eylemine kendiliğinden son vererek olay yerinden uzaklaşması hususları birlikte değerlendirildiğinde sanığın eyleminin kasten yaralama suçunu oluşturduğunun kabulü gerekmektedir", CGK, 14.5.2019, E. 2017/1-1192, K. 2019/419.

117 "Maktul ve arkadaşlarının sanığın iş yerine gelip onunla tartışma ve kavgalaşması sonrasında işyerinin camlarını kırmalarıyla gelişen olayın sanık yararına tahrik teşkil ettiği, bu halin olay tarihinden sonra yürürlüğe giren ve sanığın lehinde hükümler getirip tahrik indirimi nedeniyle öldürme suçuna ilişkin cezay1 12 yıl ile 18 yıl arasında belirlemeye elverişli olan 5237 sayılı Yasanın 29. maddesi kapsamında gerçekleştiği, işbu kışkırtma sonrasında sanığın işyerinden aldığı bıçakla saldırması üzerine maktulün direnç göstermeden ve camı kırma eylemlerini sürdürme iradesi sergilemeden kaçtığı, böylece sanığın bıçaklı saldırı evresinin "ceza sorumluluğunu kaldıran veya azaltan hukuka uygunluk nedenleri" kapsamından çıkarak tahrik etkisinde karşı saldırı niteliğine dönüştüğü, yoğun beyanlara göre 1 metrelik yakın ve etkin mesafeden, bir kısım beyana göre ise daha fazla ancak 5 metreyi aşmayan uzaklıktan, muhatabım görerek, sonuç almaya yeterli ve etkin biçimde bıçağı firlatıp sırt lomber bölgeden maktule isabet ettirdiği, bu isabetin tüm namlusu girecek ve sağ böbrek ile mideyi delerek iç kanamaya sebebiyet verecek düzeyde olduğu, bu elverişlilik tahtında da beklenen ölüm hadisesinin gerçekleştiğinin netlik kazandığı, Aletin öldürücü nitelik ve nicelik taşıdığının, aletin kullanımının ölüm sonucunu sağlamaya elverişli tarzda yapıldığının, sanığın bu kullanım kararlılık ve iradesini saptıran, etkileyen ya da yönlendiren herhangi bir dış ve iç oluşum veya faktörden söz edilemeyeceğinin ve sonuç olarak da beklenen ölüm halinin gerçekleşmiş bulunduğunun açıklık kazandığı ahvalde, derûni nitelikte olup failce saklanan kastın araştırılması ya da tahliline girişilmemesi icap ettiği, konu maddi olayda da şekillenen bu tür oluşumlarda kastın; 765 sayılı TCY'nm 452 veya 5237 sayılı yeni TCY'nın 87/4. maddesine mümas "etkili eylem sonucu ölüme sebebiyet verme-kastı aşar nitelikte 
Şekli ${ }^{118}$, atış sayısı (darbe sayısı) ${ }^{119}$ ve atış mesafesi ${ }^{120}$, failin suçtan önceki ve

insan öldürme" vasfinda yorumlanamayacağ1,", CGK. 30.01.2007,2006/1-347- 2007/19.

118 "Bu açıklamalar 1şığında somut olay değerlendirildiğinde; geceleyin, kavganın hareketli ortamında, rastgele salladığı tek bıçak darbesi ile mağduru iç organ yaralanmasına neden olmayacak biçimde yaralayan sanığın hayati bölgeleri özellikle seçtiğine ve eylemini sürdürmesine mani bir hal bulunduğuna dair kanıt da mevcut olmadığına göre, olayda yaralama kastı ile hareket ettiğinin kabulü gerekmektedir. Bu itibarla, Yerel Mahkeme direnme hükmünün bozulmasına karar verilmelidir", CGK. 8.7.2008, E. 2008/1-88; K. 2008/184; "Yaşanan kavganın, sanığın maktule husumet beslemesini ve onu öldürmek istemesini gerektirecek boyutta olmaması, zira kavgada yaralanarak asıl zarar gören ve kinlenen tarafin maktul ve arkadaşları olması, sanığın, maktulü bıçaklama anına kadar, ilk başta evde sayıca üstün oldukları da göz önüne alındığında, maktul ve arkadaşlarına yönelik herhangi bir saldırıda bulunmaması, sanığın ayağa kalktıktan sonra ani gelişen arbede sırasında, hareketli ortamda, elindeki bıçağı sallayarak tek bir öldürücü darbeyle maktulü yaralaması, diğer 2 yaranın basit tıbbi müdahale ile giderilebilecek ölçüde hafif nitelikte olması, sanı̆̆ın maktulün hayati önem taşıyan karın bölgesini hedef alarak hareket ettiğinin saptanamaması, engel bir neden olmadığı hâlde bıçakla saldırma kendiliğinden son vermesi, sanığın, arkadaşları kaçan ve yerde savunmasız şekilde yatan maktulü daha fazla yaralama ve biçağı daha çok saplama imkânı varken, elindeki bıçağı tuvalet deliğine attıktan sonra odasından getirdiği gazlı bezi arkadaşına verip maktule tampon yapmasını söyleyerek maktulün ölümüne engel olmaya çalışması karşısında; sanığın olay öncesi, olay esnası ve sonrasındaki davranışları bir bütün olarak değerlendirildiğinde, öldürme kastıyla değil yaralama kastıyla hareket ettiği, yaralama eylemiyle maktulün ölümü arasında illiyet bağ bulunduğu anlaşıldığından eyleminin kasten yaralama sonucu öldürme suçunu oluşturduğu kabul edilmelidir", CGK, 26.06.2018, E. 2018/1-166, K. 2018/308. 


\section{sonraki davranışları, failin fiiline kendiliğinden mi, yoksa engel bir nedenden}

119 "Mağdurun taksicilik yapan ağabeyinin icra müdürlüğünce yapılacak haciz işlemi için icra heyetini sanık B.. D..'ın ağabeyi İ.. D..'ın işlettiği Duranoğlu kasabına götürdüğü, İ..in haciz memuru ve alacaklıyı dükkanına getiren Hidayet'e "sen mi getirdin bunları lan" demesi üzerine çıkan tartışmanın kavgaya dönüştüğü, kavga sonrasında H.., İ.. ve M.. D..’'1n yaralandıkları, bu olay nedeniyle aynı gün tarafların Erzin Emniyet Müdürlüğüne götürüldükleri, emniyet müdürlüğünde ifade alma işlemlerinin devam ettiği sırada tarafların yakınlarının emniyet müdürlüğü etrafında toplandığı, iki grup arasında karşılıklı söz atma ve tehdit eylemlerinin yaşandığı, görevlilerin ikazları sonucunda tarafların emniyet müdürlüğü etrafından ayrılmakla birlikte çevrede bulunan kahvehanelerde beklemeye başladığı, soruşturma işlemlerinin tamamlanmasının ardından ilk olaya karışan şüphelilerden İ..'in emniyetten ayrılmasına müsade edildiği, sanık B.. ile ağabeyi İ..'in birlikte yaya olarak emniyet müdürlüğünden çıktıkları, bir süre yürüdükten sonra İsalı Köprüsü yakınlarında tanık H.. ile karşılaştıkları, tanık H..'’n aracıyla onları dükkana bırakmayı teklif ettiği, tanık H..'ın teklifi üzerine araca bindikleri, tanık H.'ın aracıyla manevra yaptığı sırada mağdurun yanında açık kimlik bilgileri tespit edilemeyen şahıslarla birlikte tanık H..'ın kullandığı aracın yanında durduğu, her iki araçta bulunan şahısların araçlardan indikleri, taraflar arasında başlayan tartışmanın kavgaya dönüştüğü, tarafların karşılıklı olarak birbirlerine saldırdıkları, kavgayı gören ve olay yerinin yakınında bir kahvede bulunan yakınlarınında kavgaya dahil olmasıyla kavganın büyüdüğü, tanık polis memuru M....'in kavgayı ayırmak için müdahale edip silahıyla havaya ateş etmesi sonucu tarafların ayrıldığı, kavga sırasında sanığın bıçakla mağdura batına nafiz olacak şekilde bir kez vurarak kolon, ince bağırsak ve diafragma yaralanmasına ve yaşamsal tehlike geçirmesine neden olacak şekilde yaraladığı anlaşılan olayda;

Sanığın ifade işlemleri tamamlanan ağabeyini almak için emniyete gelip, ağabeyi ile birlikte yaya olarak emniyetten ayrıldıktan kısa bir süre sonra yolda karşılaştıkları tanık H.... aracına bindikleri sırada mağdurun aracıyla yanında arkadaşları olduğu halde olay yerine gelmesi üzerine aniden kavganın başlaması, sanığın ani gelişen hareketli kavga ortamında mağdurun hayati bölgesine bilerek ve isteyerek vurduğuna ilişkin kesin bir belirlemenin yapılamayışı, mağdurda tek bıçak darbesinin bulunması, yaklaşık otuz kişinin karıştığı karş1ıklı kavgada sanığın mağdura vurduğu ilk darbe sonrasında öldürmeye yönelik sonucu elde ettiğini belirlemesinin mümkün olmayışı, oluşan yaralanma sonrasında sanığın eylemini devam ettirmek istediğini gösterir veya olay sırasında engel bir hal oluştuğuna ilişkin kesin delillere ulaşılamaması hususları birlikte değerlendirildiğinde sanığın eyleminin kasten yaralama olarak kabulü gerekmektedir.", CGK; 10.03.2015, E. 2013/443, K. 2015/40. “Olaydan önce, mağdur Erdal'ın, sanık Mevlüt 'ün oğlu olan tanık Yusuf'tan otuza yakın güvercin satın aldığı, birlikte zaman zaman güvercin uçurdukları, olaydan iki gün önce mağdur Erdal'ın evde olmadığ 1 bir zamanda güvercinlerinin çalındığı, mağdurun, Yusuf'tan şüphelendiği, olay günü yanında tanıklar Orhan ve Esat olduğu halde Yusuf un yaşadığ1 köye giderek kahveden çağırdığı Yusuf $u$ arabaya alarak köy dışına götürüp kuşlarını çalıp çalmadığını sorduğu, Yusuf un iddiaları kabul etmediği, mağdur ve yanındakilerin Yusuf u dövdükleri, getirip köyüne bıraktıkları, aynı gün akşam, mağdur Erdal'ın, yanına diğer sanıklar Şeref, Eyüp ve tanık Mehmet'i alarak, Yusuf'un köyüne gelerek, mezarlığın yanında buluştukları, Yusuf la konuşmaya başladıkları, burada mağdurun güvercinlerinin iadesini istediği, uluorta bağırarak küfürlü konuştuğu, olay yerine yakın alanda top oynayan aynı köyden tanık gençlerin, küfürlü konuşmadan rahatsız olduğu, mağdura ve yanındakilere tepki gösterdikleri, arabanın arkasında oturan sanık Eyüp'ün, av tüfeği ile havaya ve top oynayan tanık gençlerin üzerine doğru ateş ettiği, tanık gençlerin mağdurun arabasını taşladığ 1 , mağdur ve yanındakilerin araba ile kaçmak isterken sanık Mevlüt 'ün, mahallinde yapılan kesifte saptandığı üzere, mağdur Erdal'ı hedef alarak sekiz buçuk metre mesafeden, saklandığı ağaçların arkasından tüfekle en az iki defa olmak üzere birden fazla ateş ettiği, 
arabayı süren mağdurun saçma taneleri isabeti neticesinde sol kaşı üzerinden, frontalden, sol mandibuladan, sol oksipitalden, burnundan ve gözünden yaralandığı, sağ gözündeki yaralanmanın uzuv kaybı niteliğinde olduğu, mağdurun kullandığı araba üzerinde, şoför mahallinde yoğunlaşacak şekilde çok sayıda saçma izi meydana geldiği olayda ;

a) Atış sayısı, atış mesafesi, isabet yerleri, mağdurun arabayı hızla olay yerinden uzaklaştırması neticesinde sanığın eylemini tamamlayamaması gözetildiğinde açı̆̆a çıkan kastın öldürmeye yönelik olduğu, sanığın kasten insan öldürmeye teşebbüs suçundan cezalandırılması gerektiği düşünülmeden yazılı şekilde kasten yaralama suçundan hüküm kurulmas1,

b) Mağdurun, sanığın oğlu Yusuf u hırsızlıkla itham edip, olay günü arabasına alıp köy dışına çıkartarak yanındaki tanıklarla dövmesi, aynı gün akşam kalabalık bir grupla tekrar köye gelerek uluorta bağırıp küfür etmesi nazara alındığında, hak ve nesafet kuralları gereğince haksız tahrik uygulamasında makul bir oranda indirim yapılması gerekirken yazılı șekilde asgari düzeyde indirim yapılması", 1.CD. 16.3.2009, 9710/1319; "Sanık Muammer ve Sedat'ın aralarında alacak-borç ilişkisi nedeniyle husumet bulunan mağdurun evinin önüne gittikleri, bir süre sonra mağdurun evine doğru geldiğini görünce sanıklardan Muammer'in tabanca ile etkili mesafeden altı-yedi el ateş ederek mağduru beş isabetle pubis, sağ kruris, sağ diz, sol uyluk bölgelerinden vurarak, bir testisin alınmasına, bu nedenle organlarından birinin işlevinin sürekli zayıflamasına neden olacak şekilde yaraladığı, mağdurun giriş katta bulunan evinin balkonuna atlamak suretiyle daha fazla isabet almaktan kendini kurtardığ olayda, atış sayısı, hedef alınan vücut bölgeleri, kullanılan aletin özelliği, yaraların niteliği ve engel durumun varlığı hususları dikkate alındığında, sanıkların fiiliyle ortaya çıkan kasıtlarının öldürmeye yönelik olduğu, bu nedenle öldürmeye teşebbüs suçundan cezaland1rılmaları yerine yazılı şekilde suç vasfinın yaralama olarak kabul edilmesi suretiyle eksik ceza tayini", 1.CD. 16.7.2009, 5422/4807; "Olay günü, gece saat 02.30 siralarında alkol alarak dolaşmakta olan sanık ile ...'ın Alanya iskelesinde karşılaştıkları, sanı̆̆ın tartışmaya başladığı ....'ın yüzüne yumrukla vurması sonucu kavga çıktığı, ....'ın arkadaşları olan mağdur ile tanık ...'in kavgaya müdahale ettikleri sırada, sanığın üzerinde taşıdığı bıçağı çıkarıp sallamaya başladığı, bu esnada mağdurun batın üst bölgesine isabet eden tek bıçak darbesi sonucu karaciğer ve midesinden yaralanarak yașamsal tehlike geçirdiği, yașanan kavganın polis memurlarının gelmesi ile sona erdiği anlaşılan olayda; mağdurla aralarında husumet bulunmayan sanığın ani gelișen hareketli kavga ortamında mağdurun hayati bölgesine bilerek ve isteyerek vurduğuna ilişkin kesin bir belirlemenin yapılamayışı, mağdurda tek bıçak darbesinin bulunması, mağdurun dahil olduğu tarafin sayıca daha üstün olduğu karşılıklı kavgada sanığın mağdura vurduğu ilk darbe sonrasında öldürmeye yönelik sonucu elde ettiğini belirlemesinin mümkün olmayışı, oluşan yaralanma sonrasında sanığın eylemini devam ettirmek istediğini gösterir kesin delillere ulaşılamaması hususları birlikte değerlendirildiğinde, sanığın eyleminin kasten yaralama olarak kabulü gerekmektedir. Bu itibarla, sanığın kasten yaralama suçundan mahkûmiyetine ilişsin yerel mahkeme hükmü ve bu hükmün onanmasına dair Özel Daire kararı isabetli olduğundan, Yargıtay Cumhuriyet Başsavcıllğ 1 itirazının reddine karar verilmelidir.", CGK, 25.10.2016, E. 2016/843, K. 2016/379; “Oluşa ve dosya kapsamına göre; olay günü sinemadan çıkan sanığın, mağdurlar ile ters bakışma nedeniyle tartıştığı, tartışma sırasında sanığın, kavga ortamında rastgele savurduğu bıçakla mağdur G'yi biri toraksa nafiz olup, sağ meme başında, sol ön kolda, omuzda, sağ koltuk altında, sağ glutea bölgelerine toplam yedi kez vurarak pnömotoraksa ve yaşamsal tehlike geçirmesine sebebiyet verdiği, sanığın, eylemine devam etmeden olay yerinden kaçtığı olayda; sanığın engel hal bulunmaksızın eylemine kendiliğinden son vermesi, yaşamsal tehlikeye yol açan yaranın tek oluşu, diğer yaraların basit tıbbi müdahaleyle giderilebilir oluşu, sanık ve mağdur arasında öldürmeyi gerektirir bir husumetin bulunmaması, öldürme kastını 


\section{dolayı mı son verdiği ${ }^{121}$ gibi ölçütler göz önüne alınmak suretiyle kasten}

gösterir her türlü kuşkudan uzak, kesin ve yeterli kanıt bulunmamış olması karşısında; sanığın yaralama kastı ile hareket ettiğinin kabulü ile TCK m.86/1, 86/3-e, 87/1- d, 29, 62, 53 uyarınca hüküm kurulması gerektiği gözetilmeksizin, öldürmeye teşebbüs suçundan hüküm kurulması" bozmay1 gerektirmiştir: 1. CD; 26.11.2012, E. 2009/8411, K. 2012/8682.

${ }^{120}$ Yakın mesafeden nişan alınarak ateş edilen ve bacağın üst tarafından yaralanmanın gerçekleştiği olayda Yargıtay öldürme kastını kabul etmiştir: "Sanığın öldürücü nitelikteki av tüfeği ile katılana yakın mesafeden nişan alarak ateş etmesi sonucu tüfeğin namlusundan toplu şekilde çıkan saçma tanelerinin katılanın bacağının üst orta kısmına isabet etmesi, av tüfeği ile yakın mesafeden bacağa yönelik yapılan atışlarda, toplu saçma girişi ile geniş doku ve kemik defekti yanında ana damar ve sinir paketinin tamamen parçalanıp ani ve fazla miktarda kan kaybı sonucu kısa sürede ölümün meydana geldiğinin bilinen veya bilinmesi gereken bir durum olması, olay yerinde bulunanların sanığa müdahale ederek elindeki tüfeği almaları hususları gözününe alındığında, sanığın kastının kasten öldürme suçuna yönelik olduğunun kabulü gerekir", CGK, 02.07.2014 gün ve 134-344, İlhan/Erel/Fazla/Örer/Çakı1/ Köse/Halitoğlu/Bozoğlu/Kurşun/Kır, s. 187.

121 "Sanığın kızı olan mağdure Sevil'in evli olan diğer mağdur Mehmet ile ilişkisini onaylamadığı, bu nedenle aralarında var olan sorunların çözülmesi için tanık olarak anlatımına başvurulan diğer kızı Sibel'in eşi ve çocuğu ile birlikte İzmir'den Burhaniye'ye geldiği, söz konusu ilişki nedeniyle aralarında konuşurken mağdurun asabi davrandığ1 ve sanık olan babasına kendisine karışmamasını söyledikten sonra Mehmet'i eve çağırdığı, saat 02.00 sıralarında Mehmet'in de gelmesi ile tartışmanın büyüdüğü, mağdur Sevil'in "kimse bana karışamaz, kimseden izin alacak değilim" diyerek evli olan Mehmet ile birlikte gitmek üzere dışarı çıktığı, Mehmet'in de mağdurenin çocuğunu kucaklayarak arkasından takip ettiği, mağdurenin davranışlarına öfkelenen sanığın arkalarından gidip kesici kısmı $6.3 \mathrm{~cm}$. sap kısmı $8.5 \mathrm{~cm}$ uzunluğunda bir çakı bıçağı ile Sevil'i hayati bölgelerini hedef alarak, batına nafiz sol bölgede $3 \mathrm{~cm}$, sol kolda $8 \mathrm{~cm}$ olacak, basit tıbbi müdahale ile giderilemeyecek ve hayati tehlike geçirecek şekilde yaraladığ ikinci hamlenin diğer mağdur tarafindan müdahale edilmesi sonucunda koluna geldiği, eylemine devam etmek isteyen sanığın gürültü nedeniyle olay yerine gelen tanık Sibel tarafindan yere düşürülerek engellendiği ve Sibel'in elinden bıçağı almak için çabalaması nedeniyle hareketlerini sürdüremediği anlaşıldığından, sanığın kastının kızı olan mağdur Sevil'i öldürmeye yönelik olduğu kabul edilmelidir. Bu durumda da, icra hareketlerine başladıktan sonra diğer mağdur Mehmet ve tanık Sibel tarafından engellenmesi nedeniyle icra hareketlerini elinde olmayan nedenlerle tamamlayamaması nedeniyle hedeflenen ölüm sonucunun gerçekleşmemesine göre eylemin kasten öldürme suçuna teşebbüs olarak nitelendirilmesi gerekmektedir", CGK. 26.02.2013, E. 2012/1-1558, K. 2013/72; "Sanık ... ile ağabeyi olan inceleme dışı sanık ...'ın, yanlarında bulunan tanıklar Aydın, Zeliha, Ayşe ve Ismahan ile birlikte $\mathrm{H}$. Restoran adlı yerde gece vakti alkol alıp eğlendikleri sırada, maktul ... ve inceleme dışı sanık ... ile yanlarında bulunan tanıklar Ahmet,...., Neşet, Cihan ve Gültekin'in saat 02.30 sıralarında H. Restorana gelerek sanık ve ağabeyinin oturduğu masanın hizasında birkaç masa ileriye oturdukları ve alkol almaya başladıkları, tanık....'in, tanıklar Ismahan ve Aydın'ı tanıdığı için sanık ve ağabeyinin bulunduğu masaya giderek bir süre oturup sohbet ettiği, tanık....'in masada bulunan kadınların arasına oturması nedeniyle sanık ... ile tanık....'in arasında ufak bir sürtüşme yaşandığ 1 , bu arada maktul ...'in olaydan yaklaşık bir yıl öncesinde sanık ve ağabeyinin iş yerinden hırsızlık yaptığı iddiası nedeniyle duyduğu rahatsızlığı arkadaşı olan inceleme dışı sanık ...'ya anlatmaya başladığı, maktul ile Atilla'nın aşırı derecede alkollü oldukları, tanık....'in sanık ve ağabeyinin masasından kalkıp kendi masasına gitmesinin hemen ardından maktul ve Atilla'nın, sanık ile ağabeyi Hakan'ın 


\section{öldürme veya kasten yaralamanın var olduğu sonucuna varılmaktadır ${ }^{122}$.}

yanına giderek bu konuları konuşmak üzere dışarı çağırmaları üzerine dördünün arka arkaya dışarı çıktıkları, konuşmaya başladıkları sırada maktulün elinde bulunan bardağı sanık ...'in başına vurmasıyla birlikte kavga çıktığı, maktulün sanık ...'e yönelik saldırısını yola taşacak şekilde 1srarla sürdürdüğü, tartışma sırasında sanık ...'in üzerinde taşıdığı çakı bıçağını eline alarak ucunu açtığı, bu arada cep telefonuyla da konuşmakta olduğu, kavga üzerine dişarıya çıkan şahıslardan tanık Ahmet'in maktulü tutarak uzaklaştırıp restoran içerisine girmesini sağladığ 1 , bu arada Atilla ile Hakan arasında da kavga yaşandığ 1 ve birbirlerini darbettikleri, bu esnada içeri giren maktulün eline almış olduğu rakı şişesiyle tekrar dışarı çıkarak sırtı dönük olan Hakan'ın arkasından yaklaşarak başına vurduğu ve Hakan'ın başının kanamasına neden olduğu, bir kenarda tanık Gültekin tarafından sakinleştirilmeye çalıșılan sanık ...'in, ağabeyinin başına şişeyle vurulduğunu görmesi üzerine elindeki bıçakla birlikte hızla maktule doğru hamle yaptığı, ancak alkollü olmasının da etkisiyle dengesini kaybederek önce orada park hâlinde duran siyah renkli aracın ön kaputuna çarptığı, hemen toparlanarak sağ elinde bulunan cep telefonu ve biçakla birkaç metre ilerideki ağabeyi Hakan ile maktulün bulundukları yere geldiği, aralarında yaşanan arbede nedeniyle sanığın yine dengesini kaybettiği, bu sırada maktulün tekrar sanık ...'e yumruk savurduğu, siyah renkli aracın arka tarafiyla kaldırım arasında yere düşmekte olan sanık ...'in maktulü de sol eliyle kavraması üzerine kaldırım ile araç arasında sıkışarak birbirlerine sarılı vaziyette yere düştükleri, sanık ...'in yere düşerken ve düştükten hemen sonra üste çıkarak maktulün vücuduna hamle yaptığı, sanık ...'in ayağa kalkarak inceleme dışı sanık ...'nın üzerine yürüdüğü, maktulün ise araç ile kaldırım arasında yerde yığılı hâlde kaldığı, bir an için maktulün doğrulmaya çalıştığı, bunu gören sanık ...'in tekrar maktulün üzerine doğru giderek tekme atmaya çalıştığı ancak Hakan'ın araya girerek sanığa engel olduğu, kısa bir süre sonra tekrar yere yığılan ve hareketsiz kalan maktulün, gögüs boşluğuna nafiz bir adet delici kesici alet yarasının yol açtığ 1 perikart, kalp ve akciğer yaralanması sonucu gelişen yoğun iç kanama ve hipovolemik şok nedeniyle öldüğü olayda; yaklaşık bir yıl önce maktul ...' in kendisine ait iş yerinden hırsızlık yaptığını düşünen sanığın, olay gecesi de restoranda karşılaştı̆̆ maktulle aralarında sürtüşme yaşanması, maktul ...'in göğüs boşluğuna isabet eden öldürücü nitelikteki tek bıçak darbesinin yanında, adli raporlar ve otopsi tutanağında da belirtildiği üzere vücudunun pek çok yerinde darp cebir izinin bulunması, sanığın suçta kullandığı bıçağın öldürme suçunu işlemeye elverişli olması, kalp ve akciğerin hasar görmesi göz önüne alındığında sanık tarafından hedef alınan bölgenin hayati bakımdan önemi, olay yerinde bulunan tanıklar ile iş yeri çalışanları tarafindan uzaklaştırılmaya ve sakinleştirilmeye çalışılan sanığın, ısrarla olay yerinden gitmeyip eline aldığı bıçağın ucunu açarak maktule doğru birçok kez hamle yapması ve bıçaklanan maktulün doğrulmaya çalıştığını görmesi üzerine elinde bulunan b1çakla tekrar maktulün üzerine yürüyüp tekme atmaya çalışmak suretiyle saldırılarına devam etmesi, ancak kendisine ağabeyi Hakan'ın engel olması nedeniyle eylemine kendiliğinden son vermediğinin anlaşılması karşısında, sanığın olay öncesi, olay esnası ve sonrasındaki davranışları bir bütün olarak değerlendirildiğinde, öldürme kastıyla hareket ettiği ve eyleminin kasten öldürme suçunu oluşturduğu kabul edilmelidir.”, CGK, 20.11.2018, E. 2018/293, K. 2018/542

${ }^{122}$ CGK, 05.02.2019, E. 2015/1-705, K. 2019/59; "Sanığın katılanın amcası olduğu ve aralarında arazi anlaşmazlığı sebebiyle önceye dayalı husumet bulunduğu, olay günü sanığın katılana tabanca ile 2 el ateş ederek, karın bölgesinden bir mermi isabetiyle, peritona nafiz, yaşamını tehlikeye sokan bir duruma neden olacak şekilde yaraladığı, kullanılan vasıtanın elverişliliği, atış sayısı, atış mesafesi, meydana gelen yaralanmanın niteliği ve taraflar arasında önceye dayalı husumetin varlığı gözetilerek sanığın ortaya çıkan kastının öldürmeye yönelik olduğu, sanık hakkında kasten öldürmeye teşebbüs suçundan hüküm kurulması yerine, suç vasfinda yanılgıya düşülerek kasten yaralama suçundan hüküm kurulması...", 3. 
CGK'na göre, “Yargitay Ceza Genel Kurulunun istikrar bulunan ve süregelen kararlarında da; suç nedeni, kullanılan aletin cinsi, kullanılış şekli, isabet alınan bölge, darbe adedi ve şiddeti, failin suçtan önceki ve sonraki davranışları, aradaki husumet, hedef seçme imkânının bulunup bulunmadı̆̆l, mağdurdaki yaraların yerleri ve nitelikleri, failin fiiline kendiliğinden mi, yoksa engel bir nedenden dolayı mı son verdiği gibi ölçütler esas alınmak suretiyle kastın saptanması gerektiği belirtilmiştir. Kastın belirlenmesi açısından her bir olayda kullanılması gereken ölçütler farklılık gösterebileceğinden, tüm

CD, 26.01.2017, E. 2016/17788, K. 2017/636; “Dosya kapsamına göre, mağdurun sanığın kız kardeşiyle evli olduğu, olaydan önce tarafların bir lokantada bir araya geldikleri, alkollü ortamda başlayan tartışma sırasında yaşanan tartışmada mağdurun sanığı basit şekilde darp ettiği, ardından tarafların dağılarak gece saat 03.00 sıralarında evlerine gittikleri, sanığın evine vardığında mağdurun kardeşi olan eşi tanık....'den, mağduru öldüreceğini söyleyerek, kendisini bir bahaneyle eve çağırmasını istediği, bu istemi kabul etmeyen....'in, sanığın zorlamasıyla mağduru çağırmak zorunda kaldığı, bunun üzerine sanığın evin bahçesine saklanarak mağduru beklemeye başladığ 1 , akabinde mağdurun gelmesiyle birlikte saklandığ yerden çıkıp, aniden karın bölgesine bıçakla kuvvetlice vurduğu mağduru, ince bağırsaklarının vücuttan çıkmasına, damar yaralanmasına ve hayati tehlikeye neden olacak şekilde yaraladığı, yaralanan mağdurun kaçmaya başladığı, sanığın bıçak ile mağduru kovalamaya devam ettiği olayda, suçta kullanılan aletin öldürmeye elverişliliği, hedef alınan vücut bölgesi, darbenin şiddeti, yaranın niteliği, sanığın fiilden önceki söz ve davranışları dikkate alındığında, eylemine bağlı olarak ortaya çıkan kastının öldürmeye yönelik olduğu anlaşılan sanığın, meydana gelen zarar ve tehlikenin ağırlığı birlikte değerlendirilerek öldürmeye teşebbüs suçundan cezalandırılması yerine, suç niteliğinde yanılgıya düşülerek, yazılı biçimde kasten yaralama suçundan cezalandırılmasına karar verilmesi...”, 3 . CD, 09.02.2017, E. 2016/4159, K. 2017/1164; “Oluşa ve dosya içeriğine göre, mağdur ...'1n, saçlarının apaçi modelinde olduğu, suça sürüklenen çocuk ...'1n, ...'a "Bizim mahallede böyle dolaşamazsın" demesi üzerine çıkan tartışmada ...'1 gögüs bölgesinden hemopnömotorksa ve yaşamsal tehlike geçirmesine neden olacak şekilde tek bıçak darbesiyle yaraladığı olayda; Mağdurdaki yara sayısı ve niteliği, taraflar arasında öldürmeyi gerektirir ciddi bir husumetin bulunmaması, etkili bir engel hal olmamasına rağmen sanığın eylemine kendiliğinden son vermesi, mağdurun özellikle hayati bölgelerinin hedef alındığını gösterir somut delil bulunmaması karşısında suça sürüklenen çocuğun kastının öldürmeye yönelik olmadığı, eylemin kasten yaralama suçunu oluşturduğu gözetilmeden kasten yaralama suçundan TCK'nun 86/1. maddesi uyarınca aynı Kanunun 3. ve 61. maddesindeki ilkeler gözetilerek neticeye etkili olacak biçimde temel bir ceza belirlenmek suretiyle hüküm kurulması yerine, suç vasfinda hataya düşülerek yazılı şekilde çocuk yaştaki mağduru kasten öldürmeye teşebbüs suçundan hüküm kurulmas1...", 1. CD, 13.02.2017, E. 2017/122, K. 2017/372, "kavga sirasında sanık ...'’n ...'i bıçak ile göbek üstünde, sağ böbrek üstünde ve sağ vertebral bölgede olacak şekilde 3 ayrı yerinden yaraladığı, sol pnömotoraksa, sol 11. kaburgada kırığa, ince bağırsakta ve dalakta yaralanması nedeniyle, mağdurun hayati tehlike geçirdiği, kırığın hayat fonksiyonlarına etkisinin hafif (1.) derecede olduğunun belirlendiği, mağdurun yaralanmasının ardından sanığın olay yerinden uzaklaştığı olayda, sanığın eyleme bağlı olarak ortaya çıkan kastının öldürmeye yönelik olduğu anlaşılmakla, kasten öldürmeye teşebbüs suçundan cezalandırılması yerine suçun niteliğinde hataya düşülerek yazılı şekilde yaralama suçundan hüküm kurulması", 1. CD, 14.02.2017, E. 2017/32, K. 2017/406. 


\section{bu olguların olaysal olarak değerlendirilmesi gerekmektedir" ${ }^{123}$. Karardan}

123 CGK, 20.11.2018, E. 2018/293, K. 2018/542: "Sanık ... ile ağabeyi olan inceleme dış1 sanık ...' 'n, yanlarında bulunan tanıklar Aydın, Zeliha, Ayşe ve Ismahan ile birlikte Hayma Restoran adlı yerde gece vakti alkol alıp eğlendikleri sırada, maktul ... ve inceleme dışı sanık ... ile yanlarında bulunan tanıklar Ahmet,....., Neşet, Cihan ve Gültekin'in saat 02.30 sıralarında Hayma Restorana gelerek sanık ve ağabeyinin oturduğu masanın hizasında birkaç masa ileriye oturdukları ve alkol almaya başladıkları, tanık....'in, tanıklar Ismahan ve Aydın'ı tanıdığı için sanık ve ağabeyinin bulunduğu masaya giderek bir süre oturup sohbet ettiği, tanık....'in masada bulunan kadınların arasına oturması nedeniyle sanık ... ile tanık....'in arasında ufak bir sürtüşme yaşandı ğı, bu arada maktul ...'in olaydan yaklaşık bir yıl öncesinde sanık ve ağabeyinin iş yerinden hırsızlık yaptığı iddiası nedeniyle duyduğu rahatsızlığı arkadaşı olan inceleme dışı sanık ...'ya anlatmaya başladığı, maktul ile Atilla'nın aşırı derecede alkollü oldukları, tanık....'in sanık ve ağabeyinin masasından kalkıp kendi masasına gitmesinin hemen ardından maktul ve Atilla'nın, sanık ile ağabeyi Hakan'ın yanına giderek bu konuları konuşmak üzere dışarı çağırmaları üzerine dördünün arka arkaya dışarı çıktıkları, konuşmaya başladıkları sırada maktulün elinde bulunan bardağı sanık ...'in başına vurmasıyla birlikte kavga çıktığı, maktulün sanık ...'e yönelik saldırısını yola taşacak şekilde 1srarla sürdürdüğü, tartışma sırasında sanık ...'in üzerinde taşıdığı çakı bıçağını eline alarak ucunu açtığ çıkan şahıslardan tanık Ahmet'in maktulü tutarak uzaklaştırıp restoran içerisine girmesini sağladığı, bu arada Atilla ile Hakan arasında da kavga yaşandığı ve birbirlerini darbettikleri, bu esnada içeri giren maktulün eline almış olduğu rakı şişesiyle tekrar dışarı çıkarak sırtı dönük olan Hakan'ın arkasından yaklaşarak başına vurduğu ve Hakan'ın başının kanamasına neden olduğu, bir kenarda tanık Gültekin tarafından sakinleştirilmeye çalışılan sanık ...'in, ağabeyinin başına şişeyle vurulduğunu görmesi üzerine elindeki bıçakla birlikte hızla maktule doğru hamle yaptığı, ancak alkollü olmasının da etkisiyle dengesini kaybederek önce orada park hâlinde duran siyah renkli aracın ön kaputuna çarptığ sağ elinde bulunan cep telefonu ve bıçakla birkaç metre ilerideki ağabeyi Hakan ile maktulün bulundukları yere geldiği, aralarında yaşanan arbede nedeniyle sanığın yine dengesini kaybettiği, bu sırada maktulün tekrar sanık ...'e yumruk savurduğu, siyah renkli aracın arka tarafiyla kaldırım arasında yere düşmekte olan sanık ...'in maktulü de sol eliyle kavraması üzerine kaldırım ile araç arasında sıkışarak birbirlerine sarılı vaziyette yere düştükleri, sanık ...'in yere düşerken ve düştükten hemen sonra üste çıkarak maktulün vücuduna hamle yaptığ1, sanık ...'in ayağa kalkarak inceleme dışı sanık ...'nın üzerine yürüdüğü, maktulün ise araç ile kaldırım arasında yerde yığılı hâlde kaldığı, bir an için maktulün doğrulmaya çalıştı̆̆ bunu gören sanık ...'in tekrar maktulün üzerine doğru giderek tekme atmaya çalıştığ 1 ancak Hakan'ın araya girerek sanığa engel olduğu, kısa bir süre sonra tekrar yere yığılan ve hareketsiz kalan maktulün, göğüs boşluğuna nafiz bir adet delici kesici alet yarasının yol açtığ perikart, kalp ve akciğer yaralanması sonucu gelişen yoğun iç kanama ve hipovolemik şok nedeniyle öldüğü olayda; yaklaşık bir yıl önce maktul ...'in kendisine ait iş yerinden hırsızlık yaptığını düşünen sanığın, olay gecesi de restoranda karşılaştığı maktulle aralarında sürtüşme yaşanması, maktul ...'in gögüs boşluğuna isabet eden öldürücü nitelikteki tek bıçak darbesinin yanında, adli raporlar ve otopsi tutanağında da belirtildiği üzere vücudunun pek çok yerinde darp cebir izinin bulunması, sanığın suçta kullandığı bıçağın öldürme suçunu işlemeye elverişli olması, kalp ve akciğerin hasar görmesi göz önüne alındığında sanık tarafından hedef alınan bölgenin hayati bakımdan önemi, olay yerinde bulunan tanıklar ile iş yeri çalışanları tarafından uzaklaştırılmaya ve sakinleştirilmeye çalışılan sanığın, israrla olay yerinden gitmeyip eline aldığı bıçağın ucunu açarak maktule doğru birçok kez hamle yapması ve bıçaklanan maktulün doğrulmaya çalıştığını görmesi üzerine elinde bulunan b1çakla tekrar maktulün üzerine yürüyüp tekme atmaya çalışmak suretiyle saldırılarına devam 
da anlaşıldığı gibi ölçütlerin hepsinin gerçekleşmesi gerekmediği gibi, her olayda farklılık da gösterebilir. Bu ölçütlerin hepsinin bir olayda kullanılması da gerekmemektedir. Bazen birinin bazen birden fazlasının kullanılması mümkün olduğu gibi birden fazlasının gerçekleştĭgi olayda yaralamanın varlığı sonucuna da varılabilir. Ölçütler sınırlı sayıda olmayıp, başka kriterler de kullanılabilir. Her olay açısından ayrı ayrı değerlendirilmelidir ${ }^{124}$. Örneğin olayda tek atış olmasına rağmen öldürme kastı belirlenebilir, birden fazla ateş etme imkanı bulunmasına rağmen ilk atıştan sonra devam edilmemesi durumunda da öldürme kastı olabilirr ${ }^{125}$. Olay gönüllü vazgeçme açısından değerlendirilme kapsamına girebilir. Yargıtay hedef gözeterek, yaşamsal bölgeye gerçekleştirilen fiillerde, yaralamanın da niteliğini göz önüne alarak öldürme kastını kabul etmektedir ${ }^{126}$. Ancak yaralamanın basit tıbbi

etmesi, ancak kendisine ağabeyi Hakan'ın engel olması nedeniyle eylemine kendiliğinden son vermediğinin anlaşılması karşısında, sanığın olay öncesi, olay esnası ve sonrasındaki davranışları bir bütün olarak değerlendirildiğinde, öldürme kastıyla hareket ettiği ve eyleminin kasten öldürme suçunu oluşturduğu kabul edilmelidir".

${ }^{124}$ Gökcen/Balc1, MÜHF-HAD, s. 130, 131; Gökcen/Balc1, (2013), s. 41; Koca/Üzülmez, Özel Hükümler, s. 86-88; Tezcan/Erdem/Önok, 181, 182.

${ }^{125}$ Bkz.: Tezcan/Erdem/Önok, s. 182, 183.

126 "Oluşa ve delillere göre,sanığın hamile olduğunu bil- diği eşinin batın bölgesine bıçağını sokarak hayati tehlikeye maruz kılıp, 20 gün iş ve gücüne engel olacak şekilde yarala- dığ1 olayda,suçta kullanılan aletin niteliği, hedef alınan vücut bölgesi,meydana gelen yaranın niteliği dikkate alındığında öldürme kastıyla hareket edildiği anlaşıldığ 1 halde,öldürmeye teşebbüs yerine yaralama suçundan hüküm kurulması", 1. CD, 27.12.2006, E. 2005/4813, K. 2006/6045. "Sanık ve katılan arasında, olay öncesinde iki kez yumruklaşmaya varan kavga yaşanmış olması ve sanığın olay öncesinde bu nedenle katılanı aradığı, kaçamaklı savunmasında da belirttiği üzere karşılaştıklarında, 20-25 metre mesafeden 3 el ateş ettiği anlaşılmaktadır. Sanık, silahını kolluk görevlilerine boş olarak teslim etmiştir. Bütün bu hususlar nazara alındığında, sanık ve katılan arasında olay öncesinde kavgaya varan husumet bulunduğu, mağdura, elverişli vasıta niteliğindeki 9 mm'lik tabanca ile yine sonuç almaya elverişli mesafeden, hayati bölge niteliğindeki batın bölgesine yönelik olarak ateş ettiği, 3 el ateş ettikten sonra silahında mermi kalmadığ 1 ve mağdurun yaralandığını gördükten sonra herhangi bir müdahalede bulunmadan ya da yardım istemeden olay yerinden ayrıldığ 1 sabit olup, sanığın öldürme kastı ile hareket ettiğinin kabulünde zorunluluk bulunmaktadır; zira sanık, önceden aralarında bulunan husumet nedeniyle elverişli mesafeden, elverişli bir silah ile mağdurun hayati bölgelerini hedef seçerek, birden fazla kez ateş etmiş, mağdurun, bu atışlardan bir tanesinin isabet etmesi nedeniyle yaralanması üzerine ve silahında merminin bitmesi nedeniyle eylemine devam edememiş, onu olay yerinde bırakarak ayrılmıştır. Bu nedenle sanığın, sabit olan eylemine uyan, kasten öldürmeye kalkışma suçundan cezalandırılmasına karar verilmesi yerine, dosyadaki kantlara uymayan bir şekilde kasten yaralama suçundan cezalandırılmasına karar verilmesi isabetsizdir.”, CGK, 02.03.2010, E. 2009/1252, K. 2010/46. "Oluşa ve dosya kapsamına, özellikle tanıklar göre; sanık ... ile maktul ... arasında olaydan yaklaşık bir yıl kadar önce gönül ilişkisi yaşandığı, ancak sanık ...'nın başka birisiyle evli olması nedeniyle ilişkiye devam etmek istemeyerek maktulden ayrılmak istediğini söylemesi üzerine, maktulün sanık ... ve ailesinin adres ve telefon bilgilerini 
müdahaleyle giderilebilecek olduğu durumlarda ise, kullanılan araç, eylemi gerçekleştirmedeki ısrar, hayati bölgeye yakınlık, öldürmeye elverişli mesafe gibi özel bir takım nedenler bulunmadığ takdirde ${ }^{127}$ öldürme kastını kabul etmediği görülmektedir ${ }^{128}$. Ayrıca, sanığın ikrarı ya da diğer deliller de fiilin

internette uygunsuz sitelerde paylaştığı, sanık ...'nın birlikte yaşadığı ailesinin evine sıklıkla pasta, çiçek, tesisatçı ve saire göndererek uzun süre rahatsız ettiği, olay günü yine sanık ...'nın annesi Se.nın, kızı Ye.yi arayarak maktulün evlerine çiçek ve doğalgazcı gönderdiğini söylemesi üzerine sanık ...'nın babası ..., kardeşi sanık ..., dayıları olan sanıklar ..., ..., ... ve ile dayılarının işçileri ve arkadaşları olan sanıklar ..., ..., ... ile Ye.nin akrabası sanık ...'in bu hususu konuşmak üzere bir araya geldikleri, sanık ... aracılığıyla maktul ... Sa.nı olay yerine çağırdıkları, sanık ...'nın önden bir taksi ile olay yerine gittiği, arkadan diğer araçlarla sanıkların yanlarına sopalar, av tüfekleri ve sanık ...'in de ruhsatsız tabancasını alarak fikir ve eylem birliği içerisinde olay yerine gittikleri, burada maktulü görerek önce aracına saldırdıkları, maktulün kaçmaya çalışması üzerine arkasından av tüfeği ile ateş edildiği, ancak isabet etmediği, sanıkların birlikte hareket ederek maktulü kovaladıkları ve sopalarla darp ettikleri, bu sırada sanık ...'in tabanca ile maktulün çeşitli yerlerine ateş ettiği ve hep beraber olay yerinden araçlarına binerek uzaklaştıkları anlaşılan olayda; Sanıkların fikir ve eylem birliği içerisinde hareket ederek öldürme fiili üzerinde ortak hakimiyet kurdukları, olay yerine giderken yanlarına av tüfekleri almış olmaları nazara alındığında kastlarının öldürmeye yönelik olduğunun anlaşıldığ , bu itibarla kasten öldürme suçuna TCK'nin 37/1. maddesi kapsamında katıldıkları ve fail olarak sorumlu tutularak anılan Kanun maddesi delaletiyle TCK'nin 81. maddesi uyarınca cezalandırılmaları gerektiği gözetilmeden, yanılgılı değerlendirme sonucu yazılı şekilde kasten yaralama suçlarından hükümler kurulması", 1. CD, 22.1.2020, E. 2019/1872, K. 2020/206; "Pazarcıl1k yaparak geçimini sağlayan sanık ...'in evde olmadığı bir zamanda, eşi ...'nin mağdur ... ile görüştüğü sırada, durumun sanığın yakın akrabaları tarafından fark edilmesiyle I.' 'in evden uzaklaştığı, ertesi gün sanık ve yakınlarının görüşmek üzere mağduru otogara çağırdıkları, burada sanık ...'ın mağduru bıçakla hayati tehlike geçirmesine neden olacak şekilde yaralayarak öldürmeye teşebbüs ettiği, sanık ...'nin ise tekme ve yumruklarla katılan ...'u basit tıbbi müdahale ile giderilebilecek şekilde yaraladığı olayda", 1. CD, 3.12.2019, E. 2019/3121, K. 2019/5339.

127 "Dava, kasten öldürme suçuna ilişkindir. Katılanla aralarında önceye dayalı husumet bulunan sanığın trafikte karşılaştığında katılanın aracını 1srarla takip etmesi, sanığın öldürmeye elverişli mesafeden katılanın ölümüne mutlak gözle bakılacak hayati bölgelerine oldukça yakın olan koluna isabet etmesi, sanığın öldürmeye elverişli mesafeden ateş etmesi birlikte değerlendirildiğinde, sanığın sonuç alma veya eylemini sürdürme konusunda ciddi bir çaba içerisinde olduğu, olayın meydana geliş şekli bir bütün halinde dikkate alındığında, sanığın eyleminin katılana yönelik kasten öldürmeye teşebbüs suçu kapsamında bulunduğu ve sanık öldürme kastıyla ateş ettiğinden, atışları sırasında katılanın aracında meydana gelen hasar nedeniyle, fikri içtima hükümlerini düzenleyen TCK.nun 44. maddesi gözetilerek ağır cezayı gerektiren kasten öldürmeye teşebbüs suçundan hüküm kurulması gerekir”, 4. CD, 9.7.2019, E. 2019/4514, K. 2019/12913.

128 "Oluşa ve tüm dosya kapsamına göre sanığın birlikte yaşadığı eski eşi ile arkadaşı olan mağdur arasında bir süredir devam eden ilişki bulunduğu, olay günü mağdurun sanıkla birlikteyken yanından ayrıldığı durumdan şüphelenen sanığın kendisine ait eve geldiğinde mağdur ve eski eşini uygunsuz biçimde gördügü, mağdura çay bardağı firlattıktan sonra alt kata inip bıçak aldığı, bu arada mağdurun ve sanığın eski eşiyle bulundukları odanın kapısını kapatıp arkadan tuttuğu kapıda tekme darbesi ile delik oluşturan sanığın buradan mağdura bıçakla vurduğu, daha sonra mağdurun pencereden atlayıp kaçtığı, sanığın da elindeki bıçağı 
belirlenmesinde göz önüne alınır. Failin kastının belirlenmesinde anlam ifade ediyorsa bunlar da fiilin belirlenmesinde dikkate alınacaktır ${ }^{129}$. Doktrinde bazı yazarlar Yargıtay'ın kastla ilgili bazı kararlarında sorun bulduğunu belirtmekte ve eleştirmektedirler ${ }^{130}$.

Kastının bulunduğu tespit edilmekle beraber, bunun öldürmeye yönelik olduğu ispatlanamamışsa şüpheden sanık yararlanır ilkesi nedeniyle fail yaralamadan dolayı sorumlu tutulmalidir.

\section{Hukuka Aykırılık}

Yaşamhakkı en temel haklardan biriolmakla beraber bazı hallerdeöldürme

peşinden firlattığ 1 ancak isabet ettiremediği, netice itibariyle mağdurun basit tıbbi müdahale ile giderilebilecek şekilde yaralandığı anlaşılan olayda; sanığın öldürme kastı ile hareket ettiğine dair her türlü kuşkudan uzak, yasal ve yeterli delil bulunmadığı gözetilerek kasten yaralama suçundan TCK'nun 86/2-3-e maddeleri uyarınca cezalandırılması yerine yanılgıll değerlendirme sonucu kasten öldürmeye teşebbüs suçundan hüküm kurulması, hatalıdır", 1. CD, 11.5.2016, E. 2016/1581, K. 2016/2509; “Sanık ... hakkında mağdur ...'a yönelik olarak nitelikli yağma suçundan iddianamede yer alan TCK'nin 149/1-a-c-h şeklindeki sevk hakkında her zaman değerlendirme yapmak mümkün görülmüştür. 24.05.2015 günü gece vaktinde firına yağma amacıyla giren sanıkların kendilerine engel olmaya çalışan fırında görevli mağdur ...’i karnından ve göğsünden bıçaklayarak hayati tehlike geçirmesine neden olacak şekilde yaraladıkları ve akabinde sanıkların firının önünde duran mağdur ...'in boğazına bıçak dayayarak 130 TL parasını aldıkları ve mağdur ...'i başından ve bacaklarından basit tıbbi müdahale ile giderilebilir şekilde yaraladıkları anlaşılan olaylarda, mağdur ... 'e yönelik eylemde TCK'nin 35. maddesiyle yapılan uygulama sırasında meydana gelen zarar ve tehlikenin ağırlığı birlikte gözetilerek makul bir ceza tayini yerine yazılı şekilde 15 yıl hapis cezasına hükmolunması suretiyle eksik ceza tayini ve mağdur ...'e yönelik eylemde yağma suçunun üç nitelikli halinin oluşması gözetilerek alt sınırdan uzaklaşılarak ceza tayini yerine yazılı şekilde 10 yıl hapis cezasına hükmolunması suretiyle eksik ceza tayini karşı temyiz olmadığından bozma nedeni yapılmamıştır. SONUÇ : Toplanan deliller karar yerinde incelenip, 23.05.2015 tarihinde sanıklar ... ve ...'1n mağdur ...'a karşı nitelikli yağma suçlarının, 24.05.2015 tarihinde sanıklar ..., ... ve ...'ın mağdur ...'a karşı nitelikli yağma, mağdur ...'e karşı nitelikli kasten öldürmeye teşebbüs suçlarının, sanıklar ... ve...'’n mağdur ...'a karşı nitelikli yağma suçlarının ve sanık ...'ın müşteki ...'e karşı nitelikli kasten yaralama suçunun sübutu kabul, oluşa ve soruşturma sonuçlarına uygun şekilde suç niteliği tayin, yağma suçları açısından etkin pişmanlığa ilişkin cezayı azaltıcı sebebin nitelik ve derecesi takdir kılınmış, savunmaları inandırıcı gerekçelerle reddedilmiş, incelenen dosyaya göre verilen hükümlarde eleştiri nedenleri dışında bir isabetsizlik görülmediğinden, sanık ... müdafiinin gerekçeli temyiz dilekçelerindeki ve duruşmalı incelemedeki sübuta, vasfa ve sanık Savaşı'ın iştirak iradesi göstermediğine, sanık ... müdafiinin gerekçeli temyiz dilekçelerindeki ve duruşmalı incelemedeki sübuta, vasfa, haksız tahrike ve delillerin usule aykırı bir biçimde toplandığına ve sanık ... müdafiinin sübuta yönelen ve yerinde görülmeyen sair temyiz itirazlarının reddiyle, hükümlerin tebliğnamedeki düşünceye kısmen aykırı olarak ONANMASINA"; 1. CD, 4.6.2020, E. 2019/3879, K. 2020/1160;

${ }^{129}$ Gökcen/Balc1, MÜHF-HAD, s. 130, 131.

${ }^{130}$ Koca/Üzülmez, Özel Hükümler, s. 88. 
fiilinin gerçekleştirilmesi hukuka uygun olabilmektedir. Bir başka ifadeyle kasten öldürme suçunda hukuka uygunluk nedeni gerçekleşebilmektedir. Avrupa İnsan Hakları Sözleşmesinin 2. maddesinde, herkesin yaşam hakkının yasayla korunduğu, yasanın ölüm cezası ile cezalandırdığı bir suçtan dolayı hakkında mahkemece hükmedilen bu cezanın infaz edilmesi dışında, hiç kimsenin yaşamına kasten son verilemeyeceği belirtilmektedir. Ancak ölüm, şu belirtilen durumlardan birindemutlak zorunlu olanı aşmayacak birgüç kullanımı sonucunda meydana gelmişse, yaşama hakkının ihlali sayılmamaktadır: a) Bir kimsenin yasa dışı şiddete karşı korunmasının sağlanması; b) Bir kimsenin usulüne uygun olarak yakalanmasını gerçekleştirme veya usulüne uygun olarak tutulu bulunan bir kişinin kaçmasını önleme; c) Bir ayaklanma veya isyanın yasaya uygun olarak bastırılması.

Anayasanın 17. maddesinde de herkesin, yaşama, maddi ve manevi varlığını koruma ve geliştirme hakkına sahip olduğu düzenlenmiş, meşru müdafaa hali, yakalama ve tutuklama kararlarının yerine getirilmesi, bir tutuklu veya hükümlünün kaçmasının önlenmesi, bir ayaklanma veya isyanın bastırılması veya olağanüstü hallerde yetkili merciin verdiği emirlerin uygulanması sırasında silah kullanılmasına kanunun cevaz verdiği zorunlu durumlarda meydana gelen öldürme fiilleri, birinci fikra hükmünün ihlali sayılmamaktadır.

Yukarıda belirtilen her iki düzenlemede yer alan hükümler meşru savunma ve görevin ifası kapsamında hukuka uygunluk nedenlerini düzenlemektedir. Burada konu başlığımızla bağlantılı olarak silahın veya gücün kullanılması üzerinde durulacaktır. Devletin belirtilen durumlarda meydana gelen ölümden sorumlu tutulmaması için, gücün veya silahın belirli sınırlar içinde, meşru amaçlarla orantılı biçimde kullanılması gerekmektedir. Sözleşme'nin 2. maddesinin 2. fikrası, güç kullanımını mutlak zorunlu olanı aşmamak şartıyla hukuka uygun kabul etmektedir. Avrupa İnsan Hakları Mahkemesi, 2. fikradaki "mutlaka gerekli olandan fazla olmama" şartını, "mutlaka gereklilik" ve/veya "orant1l1l1k" kavramlariyla incelemektedir. Dolayısıyla Mahkemeye göre, devlet bir olayda görevliler tarafından kullanılan gücün "mutlaka gerekli" olduğunu ve sonra bu gücün meşru amacın gerçekleştirilmesiyle "orantılı" olduğunu kanıtlamak durumundadır. Sorun somut olaya göre değerlendirilecektir. Aniden gelişen bir olay sırasında güç kullanılmasını etkileyen faktörler ile planlı bir operasyon sırasında güç kullanılmasını etkileyen faktörler farklı olabilecektir. Bir operasyon sırasında güç kullanılması söz konusuysa, sadece güç kullanmış devlet görevlilerinin 
eylemleri değerlendirilmemekte, ayrıca bu eylemlerin planlanmasını ve denetlenmesini içeren tüm koşullar dikkate alınmaktadır ${ }^{131}$. Nachova ve Diğerleri v. Bulgaristan [BD] kararına konu olan olayda, hırsızlık suçlarından hüküm giyen iki asker 15 Temmuz 1996'da çalıştıkları inşaat sahasından kaçarak bunlardan birinin büyükannesinin evine giderler. İkisi de silahlı değildir. Bu iki askeri yakalamak üzere bir binbaşı komutasında dört kişilik ekip kurulur. Ekibi kuran albay, ekibe "kurallara uygun şekilde" tabancalarını ve otomatik tüfeklerini taşımaları ve kurşun geçirmez yelek giymeleri gerektiğini söyler. Ayrıca aktif suçlu oldukları, onların yakalanması için gerekli her türlü araca başvurmaları yönünde talimat verilir. Ekip büyükannenin evine geldiğinde, iki asker kaçmaya çalışmıştır. Teslim olmadıkları halde ateş açacağı konusunda onlara uyarı yapıldıktan sonra binbaşı otomatik tüfeğini kullanarak onları öldürmüştür. Soruşturma açılmış, binbaşının yönetmeliğe uygun davrandığı, iki askeri birkaç defa uyardığı ve havaya ateş açtığı, kaçma tehlikeleri olduğundan, yalnızca teslim olmadıkları için onları vurduğu ve onları ölümcül şekilde yaralamaktan kaçınmaya çalıştığı belirtilerek kovuşturmaya yer olmadığı kararı verilir. Avrupa İnsan Hakları Mahkemesi, ateşli silahların kullanılmasına ilişkin mevzuatın silahlı kuvvetlerin bir üyesini en ufak bir suç için dahi kişiyi yakalarken ölümcül güç kullanımına fiilen izin vermesini ciddi endişe yaratan bir durum olarak ifade etmektedir. Düzenlemelerin yetersiz ve yeterli kanuni korumaya sahip olmadığını belirtmiştir. Ayrıca operasyonu planlayan yetkililer, kaçakların silahsız oldukları ve yaşama veya beden bütünlügüne karşı bir tehlike oluşturmadıklarını dikkate almaksızın, yakalayacak olan görevlilere her türlü vasıtayı kullanma talimatı vererek, ölüm riskini asgariye indirme yükümlülüklerine uygun davranmadıklarını belirtmiştir. Son olarak da operasyona katılan görevliler, askeri olmayan işlerde çalıştırılan bu iki askerin çalıştıkları yerden şiddet kullanmadan firar ettiklerinin, şiddet suçlarından sabıkalarının bulunmadığının, silahlı olmadıklarının, kendilerini yakalamaya gelen görevlilere veya üçüncü kişilere karşı tehlike oluşturmadıklarının farkında olmalıdırlar. Her halükarda silah kullanan görevli, bu kişilerin silahlı olmadıklarını ve tehdit edici davranışlarda bulunmadıklarını gözlemlemiştir. Avrupa İnsan Hakları Mahkemesine göre, bu kişilerin kaçma riski olsa bile, Sözleşme'nin 2. maddesi kendilerine karş1 potansiyel olarak öldürücü güç kullanılmasını yasaklamaktadır. Bu kişilere karşı güç kullanılması mutlaka gerekli değildir. Mahkeme ayrıca, güç kullanan görevliyi aşırı güç kullanması nedeniyle eleştirmiştir. Çünkü bu kişileri

${ }^{131}$ Ayrıntılıbilgi için bkz.: Doğru, s. 64 vd. 
yakalamak için başka yollar vardır. Görevlilerin jipi vardır, olay küçük bir köyde gün ortasında meydana gelmiştir. Kaçakların nerede bulunabilecekleri bilinmektedir. Görevli tabanca taşıdığı halde otomatik hale getirdiği tüfeğini kullanmıştır. Kaçaklardan birinin göğsünden vurulmuş olması konusunda da ikna edici bir açıklama getirilmemiştir. Bu kişinin son anda teslim olmak için döndüğü sırada vurulmuş olması muhtemeldir. Bu nedenlerle kullanılan güç orantılı da değildir. Sözleşmenin ikinci maddesi ihlal edilmiştir ${ }^{132}$. Avrupa İnsan Hakları Mahkemesi, Sözleşmenin 2. maddesinin 2. fikrasında gösterilen amaçlarla güç kullanılmasını değerlendirirken, o sırada sağlam gerekçelerle geçerli görünen samimi bir inanca dayanıp dayanmadığına da bakmakta, daha sonra bu inancın hatalı olduğu anlaşılsa bile, bu madde bakımından haklı görülebileceğini kabul etmektedir. Aksini düşünmenin devlete ve kolluğa görevlerini yaparlarken, belki de kendilerinin ve diğerlerinin yaşamlarına zarar verebilecek gerçekçi olmayan bir külfet yüklemek olduğunu ifade etmektedir ${ }^{133}$. Avrupa İnsan Hakları Mahkemesi hem kasten gerçekleştirilen yaşam ihlallerini hem de taksirle gerçekleştirilen yaşam ihlallerini 2. madde kapsamında kabul etmekte, taksirle işlenen fiillerin kabul edilebilir olduğunu görebilmekte, ancak bu halde yaşamı koruma yükümlülüğü açısından değerlendirme yaparak belirleme yapmaktadır. Avrupa İnsan Hakları Mahkemesine göre, yaşamdan yoksun bırakmanın haklı görülebileceği haller dar yorumlanmalıdır. Bu bağlamda ulusal hukuk uygulanırken Sözleşme ve BM belgeleri dikkate alınacak olursa, tüm haklara yönelik saldırılara karşı değil ama sadece kişinin yaşamına veya maddi ve manevi bütünlügüne yönelik bir saldırıya karşı öldürücü güç kullanılabileceği kabul edilebilir. Mahkemeye göre, Sözleşmenin 2/2 .maddesi öldürmeye izin vermemekte, istenmeyen sonuç olarak yaşamdan yoksun kalma sonucu doğurabilecek güç kullanılmasına izin verilen durumları göstermektedir ${ }^{134}$. Elinde silah olmayan, yakalayacak kişinin hayat ve beden bütünlüğünü tehdit etmeyen, şiddetli suç işleme şüphesi altında olmayan bir kişinin yakalanma imkanının kaybedilmesine yol açacak olsa bile yaşamın tehlikeye sokulmasının meşru sayılamayacağı kabul edilmektedir ${ }^{135}$. Kişilerin şiddet suçları işlemiş olduklarına ve tehlikeli kişiler olduklarına ve yakalanmamaları halinde telafi edilemeyecek zararlı sonuçlar

\footnotetext{
132 https://www.failibelli.org/wp-content/uploads/2020/03/nachova-ve-digerleri-bulgaristan. pdf; Nachova ve diğerleri/Bulgaristan [BD], no. 43577/98 ve 43579/98, 6/7/2005, § 105, 106, 107; Doğru, s. 115, 116.

${ }^{133}$ Doğru, s. 66.

134 Doğru, s. 78, 61, 51, 48.

135 Tezcan/Erdem/Önok, s. 188.
} 
meydana geleceğine inanmaları için bir neden bulunmadığı durumlarda silah kullanılması 2. maddenin ihlali olarak görülmektedir. Mahkeme belirtilen koşullarda, polisin gece yarısı yağmurdan kayganlaşmış zeminde elde tabanca kaçakların arkasından koşmakla bu kişilerin hayatını tehlikeye attığ kanaatine ulaşmaktadır. Yakalama için hareket edilen hallerde yaşamın korunması için gereken tedbirlerin alınması gerektiği kabul edilmektedir ${ }^{136}$.

Hukukumuz açısından görevin ifası hukuka uygunluk nedeni kapsamında özellikle PVSK'daki silah kullanma yetkisi üzerinde durulacaktır. Bazı kanunlarda silah kullanma yetkisine ilişkin belirlemeler bulunmaktadır. 5607 sayılı Kaçakçılıkla Mücadele Kanununun 22. maddesi ${ }^{137}$, 2803 sayılı Jandarma Teşkilat, Görev ve Yetkileri Kanununun 11. maddesi ${ }^{138}$ (ayn1 zamanda PVSK m. $25^{139}$ ), Terörle Mücadele Kanununun ek 2. maddesi ${ }^{140}$, Polis Vazife Salahiyet Kanununun 16. maddesi bunlardan bazılarıdır. Meşru savunma durumunda ister kanunlarda düzenleme olsun isterse olmasin herkes gibi kolluğun da silah kullanma yetkisi ${ }^{141}$ bulunmaktadır. Bu durumda ilgili kanun hükümlerine gitmeden meşru savunmanın şartları içinde değerlendirme yapmak gerekmektedir. Bunun dışındaki hallerde ilgili kanunlarda yer alan düzenlemelerin belirlediği sınırlar içinde yetki kullanılmalıdır. Örneğin PVSK

${ }^{136}$ Alikaj ve Diğerleri v. İtalya kararı için bkz.: Doğru, s. 54-56.

137 22. madde, "(1) Gümrük Kanunu gereğince belirlenen kap1 ve yollardan başka yerlerden gümrük bölgesine girmek, çıkmak veya geçmek isteyen kişiye "dur" uyarısında bulunulmasına rağmen bu uyarıya uymaması halinde, havaya ateş edilmek suretiyle uyarı yinelenir. Ancak silâhla karşıllğa yeltenilmesi ve sair surette meşru müdafaa durumuna düşülmesi halinde, yetkili memurlar saldırıyı etkisiz kılacak oranda doğrudan hedefe ateş edebilir. Memurların silâh kullanmalarından dolayı haklarında soruşturma ve kovuşturma açılması halinde, bağlı bulunduğu kurum tarafından avukat sağlanır ve avukatlık ücreti kurumlarınca karşılanır. (2) Kaçakçılığı önleme, izleme ve araştırmakla yükümlü olanlar, gümrük bölgesindeki her nevi deniz araçlarına yanaşıp yük ve belgelerini incelemeye yetkilidir. Görevlilerin yanaşmasına izin vermeyerek kaçan veya kaçmaya teşebbüs eden her nevi deniz araçlarına uluslararası deniz işaretlerine göre telsiz, flama, mors ve benzeri işaretlerle durması ihtar olunur. Bu ihtara uymayan deniz araçlarına uyarı mahiyetinde ateş edilir. Buna da uymayıp kaçmaya devam ettiği takdirde durmaya zorlayacak şekilde üzerine ateş edilir.”

138 11. madde, “-Jandarma, kendisine verilen görevlerin ifası sırasında hizmet özelliğine uygun ve görevin gereği olarak kanunlarda öngörülen silah kullanma yetkisine sahiptir."

139 25. madde, "Polis teşkilatı bulunmayan yerlerde il, ilçe ve bucak jandarma komutanları ile jandarma karakol komutanları bu kanunda yazılı vazifeleri yapar ve yetkileri kullanırlar".

${ }^{140}$ Ek madde 2, "Terör örgütlerine karşı icra edilecek operasyonlarda "teslim ol" emrine itaat edilmemesi veya silah kullanmaya teşebbüs edilmesi halinde kolluk görevlileri, tehlikeyi etkisiz kılabilecek ölçü ve orantıda, doğrudan ve duraksamadan hedefe karşı silah kullanmaya yetkilidirler."

${ }^{141}$ Kolluk ve silah kullanma yetkisi ile ilgili olarak bkz.: Cin, s. 665 vd. 
m. 16'da (7. ve devamı fikraları), Polisin,

a) Meşru savunma hakkının kullanılması kapsamında,

b) Bedenî kuvvet ve maddî güç kullanarak etkisiz hale getiremediği direniş karşısında, bu direnişi kırmak amacıyla ve kıracak ölçüde,

c) Hakkında tutuklama, gözaltına alma, zorla getirme kararı veya yakalama emri verilmiş olan kişilerin ya da suçüstü halinde şüphelinin yakalanmasını sağlamak amacıyla ve sağlayacak ölçüde,

d) Kendisine veya başkalarına, işyerlerine, konutlara, kamu binalarına, okullara, yurtlara, ibadethanelere, araçlara ve kişilerin tek tek veya toplu olarak bulunduğu açık veya kapalı alanlara molotof, patlayıc1, yanıcı, yakıc1, boğucu, yaralayıcı ve benzeri silahlarla saldıran veya saldırıya teşebbüs edenlere karşı saldırıyı etkisiz kılmak amacıyla ve etkisiz kılacak ölçüde" silah kullanmaya yetkili olduğu belirtilmektedir. Polis, yedinci fikranın (c) bendi kapsamında, yani hakkında tutuklama, gözaltına alma, zorla getirme kararı veya yakalama emri verilmiş olan kişilerin ya da suçüstü halinde şüphelinin yakalanmasını sağlamak amacıyla ve sağlayacak ölçüde kolluk silah kullanmaya yetkilidir. Ancak bu durumda polisin önce kişiye duyabileceği şekilde dur çağrısında bulunması, çağrıya uymayarak kaçmaya devam etmesi halinde ise uyarı amacıyla silahla ateş etmesi, buna rağmen kaçmakta 1srar etmesi dolayısıyla ele geçirilmesinin mümkün olmaması halinde ise kişinin yakalanmasını sağlamak amacıyla ve sağlayacak ölçüde silah kullanması gerekir. Dolayısıyla silahın son çare olarak kullanılması söz konusudur. Yakalama yetkisi çerçevesinde silah kullanılması durumunda meşru savunma hali söz konusu olmadığı için kişinin yakalanmasını sağlayacak ölçüde silahın kullanılması gerekir. Silah kullanmayla ilgili olarak dikkat edilmesi gereken nokta, ilgili düzenlemelerde getirilen kurallara ve sinırlamalara uyulması gerekmekle beraber meşru savunma ile bunun dışındakileri ayırmak gerekir. Eğer meşru savunma kapsamına giren bir durum varsa şartları içinde saldırıyı etkisiz kılmak amacıyla ve etkisiz kılacak ölçüde meşru savunma şartları içinde silahın kullanılması hukuka uygunluk teşkil edecektir. Diğer hallerde ise ilgili düzenlemelerde belirtilen şartlar dahilinde silah kullanılması gerekmekle birlikte bazı hususlara dikkat edilmelidir. Bir kere silah kullanmak durumunda kalınan kişinin çocuk veya yetişkin olmasının göz önüne alınması gerekir. Çocuklarda özgürlüğü kısıtlamak son çare olduğu için (Çocuk Koruma Kanunu m. 4/1-i) kaçan çocuğun özgürlüğünün kısıtlanmasını sağlamak için silah kullanılmasının tercih edilmemesi gerekir. Dur ihtarının yapılması, 
havaya ateş edilmesi söz konusu olabilir, ancak çocuğa karşı silahla ateş edilmemesi gerektiğini düşünüyoruz. Çok çok istisnai durumlarda uygulanmas1 gerekir. Yetişkinlerde kabul ettiğimiz esaslar çocuklarda çok daha sınırlı kullanılmalıdır. Yetişkinlerde de kişinin yakalanması için dur ihrarı, havaya ateş edilmesi mümkündür. Ancak yakalanmamaları halinde telafi edilmeyecek zararlı sonuçlar ortaya çıkmayacaksa, tehlikeli olduklarına ve şiddet suçlarını işlediklerine ilişkin durum yoksa silah kullanılmaması gerekir. Kaçmakta ısrar etmesi nedeniyle ele geçirilmesinin mümkün olmaması, yakalanma imkanının kaybedilmesi yaşamını tehlikeye sokacak şekilde silah kullanılması için yeterli olmaması gerekir. Tersi durumda silah kullanılabilir, ancak bu takdirde de yakalanmalarını sağlamak amacıyla yakalanmalarını sağlayacak ölçüde kullanılması gerekir. Burada da kişiyi öldürecek şekilde ateş edilmesi söz konusu değildir ${ }^{142}$. Bu ölçünün aşılması durumunda ise hukuka uygunluk sebebinde sınırın aşılması çerçevesinde değerlendirme yapılmalıdır ${ }^{143}$.

Yargıtay görevin yerine getirilmesiyle bağlantılı olarak sınırın kasten aşılmasının söz konusu olduğu olaylarda, m. 27/1'in uygulanmasını kabul etmemekle birlikte failin kastının yaralamaya yönelik olduğu nitelendirmesini yapmakta ve netice sebebiyle ağırlaşan suçtan (TCK m. 87/4) hüküm kurulmasını kabul etmektedir ${ }^{144}$. Ancak sınırın aşılmasında kişinin taksirinin

${ }^{142}$ Silah kullanma yetkisi hakkında geniş bilgi için bkz.: Özgenç, Türk Ceza Hukuku, s. 335 vd.

143 "Görevli ve yetkili bulunan polis memuru sanık ve arkadaşlarının, bir gün önce görevli bulundukları mülki sınırlar içinde işlenen suç gasp suçu nedeniyle aranan maktul ve arkadaşlarına rastlayıp, onları yakalamaya çalışmaları üzerine, maktul ve arkadaşlarının da sanık ve diğer polis memurlarına kırmak suretiyle silah haline getirdikleri şişelerle saldırıda bulunmaları üzerine, sanığın yaptığı uyarı ateşi sonrası polis memurlarının elinden kurtularak kaçan maktulü, yakalamak için dur ihtarında bulunarak silahla ateş etmesi yasa gereği ise de, suçlunun öldürülmekten ziyade yaralı olarak yakalanmasına dikkat edilmesi gerektiği kuralına aykırı davranılmak suretiyle, silah kullanma hak ve yetkisinin icrasında aşırılığa kaçırılarak yasağa uygunluk sınırının aşıldığı kabul edilmelidir”: CGK, 22.3.2005 gün ve 219/35, İlhan/Erel/Fazla/Örer/Çakıl/Köse/Halitoğlu/Bozoğlu/Kurşun/Kır, s. 104.

144 "askerlik hizmetini yerine getirmek için silah altında bulunan sanık Piyade Er ... ile maktul ...'ın olaydan önce birbirlerini tanımamaları, aralarında öldürmeyi gerektirecek bir husumetin bulunmaması, maktulün tanık .....'u kovaladığı sırada sanığın yumruk atarak maktule müdahale etmesinden sonra yumruğun tesiri ile yere düşen maktulün sanığa doğru hamle yapması üzerine sanığın tüfeğinin ucuna takılı süngüyle maktulün gögüs bölgesine bir kez vurması, maktulün göğüs bölgesinden kan geldiğini görünce herhangi bir engel durum bulunmamasına karşın eylemine kendiliğinden son vermesi, olay günü saat 20.17'de güneşin battığı göz önüne alındığında havanın kararmaya başladığı ortamda çıkan arbede sırasında sanığın özellikle maktulün hayati önem taşıyan gögüs bölgesini hedef alarak hareket ettiğinin saptanamaması, maktulün vücudundaki ikinci kesici delici alet yarasının maktulün bacağında yer alması, sanığın olaydan hemen sonra yardım getirmesi için tanık .....'u Karakola göndermesi karşısında; sanığın olay öncesi, olay esnası ve sonrasındaki davranışları 


\section{bulunduğunu kabul ettiği olaylarda m. 27/1'in uygulanmas1 ${ }^{145}$ yoluna gitmektedir $^{146}$.}

bir bütün olarak değerlendirildiğinde, öldürme kastıyla değil yaralama kastıyla hareket ettiği, yaralama eylemiyle maktulün ölümü arasında illiyet bağı bulunduğu anlaşıldığından eyleminin kasten yaralama sonucu öldürme suçunu oluşturduğu kabul edilmelidir", CGK, CGK, 05.02.2019, E. 2015/1-705, K. 2019/59. "Sanık polis memurunun, yerleşim alanı olduğu cadde üzerinde dur ihtarına uymayarak, motosikleti ile uzaklaşmakta olan maktulün arkasından, durdurmak gayesiyle önce havaya, sonra maktulün bulunduğu istikamete olmak üzere toplam iki kez ateş ettiği sırada, kurşunlardan birinin isabet etmesi sonucu maktulün ölümüne neden olduğu olayda, sanığın eyleminin 5237 sayılı TCY'nın 87/4. maddesinde düzenlenmiş bulunan netice sebebiyle ağırlaşmış yaralama sonucu ölüme neden olma suçunu olușturduğunun kabulü gerekmektedir”, CGK, 05.06.2012 gün ve 840-214, İlhan/Erel/ Fazla/Örer/Çakı1/Köse/Halitoğlu/Bozoğlu/Kurşun/Kır, s. 79. "Somut olayda hakkında tutuklama kararı verilen ancak kelepçe takılmadığından yararlanarak kaçan şüpheliyi yakalamak için yaralama kastıyla hareket eden ve sınırı kasten aştığı hususunda duraksama yaşanmayan sanığın eyleminin T.C.K.nın 27/1. maddesi kapsamında değerlendirilemeyeceği, meydana gelen sonucu kabullenerek hareket ettiğine dair kanıt bulunmadığından eylemin olası kastla öldürme suçu kapsamında da değerlendirilemeyeceği, yaralamak suretiyle etkisiz hale getirme kastıyla hareket eden sanığın eylemi neticesi meydana gelen ölümden T.C.K.nın 87/4. maddesi gereğince sorumlu tutulması gerektiği ve sanığın T.C.K.nın 87/4. maddesi gereğince mahkûmiyeti yerine atılı șekilde T.C.K.nın 85/1 ve 27/1. maddeleri gereğince mahkûmiyetine hükmedilmesi, kanuna aykırıdır", 12. CD, 01.07.2015, E. 2014/18098, K. 2015/12307. Ayn1 yönde 3. CD, 26.02.2015, E. 2014/26755, K. 2015/7413.

${ }^{145}$ Silifke Yeşilovacık Limanından hareket eden "Hayri Reis" isimli tekne ile yurt dışına yasal olmayan yollardan insan çıkarılacağı yönünde ihbar alınması üzerine, olay günü saat 04.00 sıraları içinde maktul ...'1n da bulunduğu 236 kaçak yolcu ile birlikte hareket eden adı geçen teknenin, Akdeniz Bölge Sahil Güvenlik Komuntanlığı'na bağlı TCSG 73, TSCG 116 ve TSCG 103 botları tarafindan takibe alındığı, tüm uyarı ve çabalara rağmen durdurulamaması üzerine uyarı atışları yapıldığı, geminin ısrarlı bir şekilde devam etmesi üzerine gemiyi hareketten sakıt bırakmak amaçlı pervane kısmına halat atılması emrinin verildiği, bu şekilde de durdurulamaması üzerine Sahil Güvenlik Akdeniz Bölge Komutanı'nın emriyle geminin pervane ve kıç kısmına atışlar yapıldığı, bu atışlar sebebiyle tekneye isabet eden kurşunların kopardığı, niteliği belirlenemeyen bir parçanın maktulün sağ koltuk altından isabet etmesiyle hayatını kaybettiği olayda; Sanık ... haricinde "Hayri Reis" isimli teknenin pervane ve kıç kısmına ateş eden başkaca görevli bir deniz astsubayı bulunmadığı, bu haliyle maktule isabet eden cismin, sanık ... tarafından gemiye yapılan atışlar sonucu gemiden koptuğu, sanık ...'1n atışları sonucu maktulun hayatını kaybettiği anlaşılmakla, sanık hakkında yukarıda belirtilen mevzuat hükümleri ve TCK'nun 24. ve CMK'nun 223/3-b. maddeleri uyarınca ceza verilmesine yer olmağına karar verilmesi yerine yazılı şekilde beraatine karar verilmesi, bozmay1 gerektirmiş olup", 1. CD, 26.12.2017, E. 2016/2333, K. 2017/5316. Olayda sınırın aşılması söz konusu olmakla beraber (TCK m. 27/1), Yargıtay hukuka aykırı bağlayıcı emir nedeniyle ceza verilmesine yer olmadığı kararının verilmesini kabul etmiştir.

146 "Hakkında yakalama kararı bulunan maktulün kaçmasını engellemek için uyarıda bulunduğu, maktulün buna rağmen kaçmaya devam etmesi nedeniyle de öldürme kastı olmaksızın maktulün ayaklarına doğru ateş ederek yakalamayı amaçladığı, ancak; aksi sabit olmayan savunmasına göre bu sırada ayağının kayıp yere düşmesi nedeniyle; hedefi tam olarak ayarlayamadığı ve mermilerden bir tanesinin maktulün sırt bölgesine isabet ederek ölümüne neden olduğu olayda; polis memuru sanığın ve ekip arkadaşı tanık Olcay'ın yaptığı sözlü ve ateşli uyarılarına direnerek kaçan maktülü, yakalamak için kademeli olarak silahla ateş 
etmesi yasa gereği ise de, Polis Vazife ve Selahiyet Tüzüğünün 17. maddesinde belirtilen "suçlunun öldürülmekten ziyade yaralı olarak yakalanmasına" ilişkin amir hükmüne gerekli özenin gösterilmediği, olayın oluşu, sanığın olay anındaki durumu ve atış sayısı dikkate alındığında, hukuka uygunluk nedenlerinden Kanunun emrini yerine getirmede silah kullanma hak ve yetkisinin icrasında aşırılığa kaçarak, yasaya uygunluk sınırının kast olmaksızın taksirle aşılması söz konusu olduğundan, TCK.nun 24/1, 27/1 ve 85/1 maddeleri uyarınca aynı Kanun'un 3. ve 61. maddesindeki ilkeler doğrultusunda, kusurunun ağırlığ nedeniyle taksirle ölüme neden olma suçundan üst sınıra yaklaşmak suretiyle ceza tayini gerektiği gözetilmeden, yazılı şekilde kasten yaralama sonucu ölüme neden olma suçundan hüküm kurulması suretiyle suç vasfinda yanılgıya düşülmesi bozmayı gerektirmiştir", 1. CD, 10.12.2015, E. 2015/5248, K. 2015/6085; "Oluşa ve dosya kapsamına göre; polis memuru olan sanığın, olay günü kamuoyunda Gezi Parkı Olayları olarak bilinen Kızılay Güvenpark bölgesinde görevlendirildiği, söz konusu olaylar sırasında, göstericiler tarafından birçok kamu malına zarar verildiği, güvenlik güçlerine yönelik taşlı sopalı saldırılarda bulunulduğu, artan saldırılar sebebiyle sanığın bulunduğu bölgede görev yapan güvenlik güçlerine Başbakanlığı korumak için geri çekilme talimatı verilmesi üzerine, Çevik Kuvvet Birliklerinin geri çekilmeye başladıkları, ancak; kendilerine yönelik saldırılar yüzünden düzenli şekilde çekilemedikleri ve bazı çevik kuvvet mensuplarının Güvenpark'ın içinde sıkıştıkları, sanık ve yanındaki bir kaç arkadaşının da bu şekilde geri çekilmek üzere parkı terk ederken bazı göstericilerin saldırısına uğradıkları, sanığın aldığı darbe yüzünden elindeki kalkanı düşürdüğü, kendisinin de yere düştüğü, parktan çıktığı sırada kendisine yöneldiğini düşündügü bir göstericiye onu uzaklaştırmak için tekme attığı, ardından bu göstericinin arkasındaki, içinde maktulün de bulunduğu bir grup göstericiyle karşı karşıya kaldığı, gösterici grubunun kendisine yönelik yoğun taşlı saldırısını o andaki hal ve koşullara göre saldırıyla orantılı biçimde PVSK.nun 16/6-a maddesi kapsamında havaya ateş etmek suretiyle def etmek istediği, arka arkaya gerçekleşen 3 atıştan, ilk ikisinin havaya, sonuncusunun ise aldığı taş isabetleri yüzünden silah üzerindeki hakimiyetini kaybetmesi sonucu, karşısındaki grubun içinde bulunan maktulün sağ parietotemporal bölgesine isabet ettiği olayda, TCK. nun $27 / 1$ ve 85/1. maddeleri uyarınca aynı Kanunun 3 ve 61. maddesindeki ilkeler doğrultusunda taksire dayalı kusurunun ağırlığı sebebiyle taksirle ölüme neden olma suçundan, sonuca etkili olacak şekilde teşdiden ceza tayini gerektiği gözetilmeden, yazılı şekilde alt sınırdan ceza belirlenmesi", 1. CD, 5.12.2017, E. 2017/1474, K. 2017/4723. "Bir başka suç nedeniyle sevkedildiği mahkemede hakkında CMK'nın 94. maddesi uyarınca tutuklama kararı verilmesi üzerine kelepçe bağlanmaksızın sevki sağlanan ölen, adliye çıkışında kolluk görevlilerince naklinin sağlanmasından önce ailesi ile vedalaştığı sırada, kolluk görevlilerinin bir anlık dalgınlığından istifade ederek hızla ara sokaklara doğru kaçmaya başladığı, yakalamak için peşinden koşan kolluk görevlilerin öleni takibe geçtikleri, sözlü ikaza ve uyarı atışlarına rağmen durdurulamadığı ve kaçışına devam ettiği, polis memuru olan sanığın koşarak takipte olduğu sırada ilerlediği sokağın cadde ile kesişim noktasındaki merdivenlerden inerken dengesini kaybederek düştüğü ve buradan yarı otomatik tabancasıyla yaptığı atışlar neticesi silahından çıkan mermilerden birinin ileride cadde üzerinde kaçışını sürdüren ölenin sol omuz bölgesini sıyırarak geçtiği, diğer merminin ise ölenin kafasında sağ oksipito parietal bölgeden girip, beyinde hasar meydana getirerek kafada alın sağ orta kısım yakınından çıktığ 1 , cilt-cilt altı bulgulara göre her iki atışın da uzak atış mesafesinden yapıldığı, atışlardan birinin de yolun solunda park halindeki aracın arka cam sağından girip ön cam solundan çıkarak yol kenarındaki betonarme kolona isabet ettiği, bu alanda da gömleksiz bir adet ateşli silah mermi çekirdeğinin elde edildiği, ara sokaklarda ve merdivenlerin bitiminde sanığın silahından yapıldığı anlaşılan ikişer adet kovanın ele geçirildiğ sanığın düştükten sonra ateş ettiği yer ile ölenin vurulduğu yer arasında yaklaşık 23 metrelik bir mesafenin olduğu, mermi çekirdeklerinin yerden en az bir metre yüksekteki (duvar ve 
Kasten öldürme suçu kapsamında uygulanacak diğer bir neden meşru savunmadır. Meşru savunma bir kimsenin kendisini veya başkasını hedef alan saldırıyı defetmek için savunma amacıyla saldırıyı defedecek ölçüde işlenen fiildir ${ }^{147}$. Örnek olarak kendisini silahla öldürmek için ateş eden kişinin silahla öldürülmesi verilebilir ${ }^{148}$. Karşılıklı çatışma ve kavga hallerinde ise meşru savunmadan ilk haksız saldırıya uğrayanın yararlanacă̆ 1 kabul edilmektedir ${ }^{149}$. Ancak saldırıyı kimin başlattığının tespit edilememesi durumunda sorun tartışmalıdır. Bir görüş ilk saldırıyı kimin başlattığı tespit edilemiyorsa meşru savunma hükümlerinin uygulanmaması, her iki taraf için de haksız

otomobildeki) isabet bölgeleri, ölenin vücudundaki temas noktaları ile atış süresi dikkate alınarak mekanik arızası bulunmadığı tespit edilen yarı otomatik bir silahla Polis Vazife ve Selahiyet Kanunu'nun 16. maddesinde belirtilen “...kişinin yakalanmasını sağlamak amacryla ve sağlayacak ölçüde silahla ateş edebilir" hükmüne aykırı olarak ateş ederek kaçan şüphelinin ölümüne sebebiyet verdiği iddia ve kabul edilen olayla ilgili olarak,... hakkında tutuklama kararı verilen ancak kelepçe takılmadığından yararlanarak kaçan şüpheliyi yakalamak için yaralama kastı ile hareket eden ve sınırı kasten aştığı hususunda duraksama yaşanmayan sanığın eyleminin TCK'nın 27/1. maddesi kapsamında değerlendirilemeyeceği, meydana gelen sonucu kabullenerek hareket ettiğine ilişkin kanıt bulunmadığından eylemin olası kastla öldürme suçu kapsamında da değerlendirilemeyeceği, yaralamak suretiyle etkisiz hale getirme kastıyla hareket eden sanığın eylemi neticesi meydana gelen ölümden TCK'nın 87/4. maddesi gereğince sorumlu tutulmasi gerektiği ve sanığın TCK'nın 87/4. maddesi gereğince mahkumiyeti yerine atılı şekilde TCK'nın 85/1 ve 27/1. maddeleri gereğince mahkumiyetine hükmedilmesi" şeklindeki bozma gerekçesinin sonucu bakımından usul ve kanuna uygun olduğundan, kararda değişiklik yapılmasına yer olmadığına", 12 . CD, 22.03.2017, E. 2017/148, K. 2017/2261.

${ }^{147}$ Hâkim görüşe göre, meşru savunmada hukuka aykırı saldırı, hem hukuka hem de bireysel değerlere saldırı niteliği taşımaktadır. Bu nedenle meşru savunmada hem hukuk düzeninin hem de saldırıya uğrayanın bireysel değerlerinin savunulduğu ifade edilmektedir. Bkz.: Engländer, s. 8.

148 Örnekler için bkz.: Mitsch, s. 85.

149 "soruşturma aşamasında emniyet görevlilerince yapılan CD çözümleme tutanağında da tartışma devam ederken ...'in...e yumruk attı̆̆ının,... yere düştükten sonrada ...'in eylemlerine devam ettiğinin belirtildiği, Mahkemesince olay CD'sinin izlenmediği, tüm bu değerlendirmeler karşısında gerek tanık beyanları gerekse de olay yerini gösterir kamera kayıtlarının yapılan çözümlemesine ilişkin bilirkişi raporlarında taraflar arasında meydana gelen tartışma sonrası ilk olarak sanık ...'1n sanık ...'e yumruk atarak onu yere düşürdüğünün sabit olduğu, sanık...in kendisini korumak amacıyla sanık ...'e karşı tekme attığ 1 , sanık...in eyleminin meşru savunma kapsamında kaldığ 1 , bu nedenle 5237 say1lı Kanun'un 25/1. maddesinde yer alan, "Gerek kendisine ve gerek başkasına ait bir hakka yönelmiş, gerçekleşen, gerçekleşmesi veya tekrarı muhakkak olan haksız bir saldırıyı o anda hal ve koşullara göre saldırı ile orantılı biçimde defetmek zorunluluğu ile işlenen fiillerden dolayı faile ceza verilmez." şeklindeki düzenleme karşısında sanık hakkında meşru savunma hükümleri uyarınca ceza verilmemesi gerektiği gözetilmeden, yazılı şekilde mahkumiyetine karar verilmesinde, isabet görülmediğinden bahisle", 3. CD, 04.10.2017, E. 2017/11445, K. 2017/12177. 
tahrik hükümlerinin geçerli olması gerektiğini savunmaktadır ${ }^{150}$. Yargıtayın da haksız tahrik hükümlerini uyguladığı kararları bulunmaktadır ${ }^{151}$. Diğer görüş ise, taraflardan birinin meşru savunmada olduğu muhakkak olduğundan bu kişinin mahkûm olmasının adaletsiz olacağını, ayrıca şüpheden sanık yararlanır ilkesine de aykırılık teşkil edeceğini belirtmektedir. Dolayısıyla da her iki tarafın meşru savunmadan yararlanması gerektiğini kabul etmektedir ${ }^{152}$.

Meşru savunma içinde hareket ederken sınırın taksirle aşılması durumunda TCK m. 27/1 uygulanacak ve kişi fiilin taksirli şeklinden indirilmiş cezayla sorumlu tutulacaktır. $\mathrm{Bu}$ hükmün uygulanması için ölçüde sınırın aşılması gerekir. Meşru savunmada sınırın aşılması mazur görülebilecek bir heyecan, korku veya telaştan ileri gelmiş ise 27/2 uygulanacak ve fail cezalandırılmayacaktır. Örneğin savunmada bulunan kişi bir kez ateş etmekle saldırıdan kurtulacakken birden fazla ateş ettiğinde sınırın aşılması ${ }^{153}$ söz konusudur ${ }^{154}$. Sınırın heyecan, korku veya telaştan

150 Öztürk/Erdem, s. 273.

151 “Sanığın maktule borçlu olduğu ve bu borcu uzun bir süredir ödemediği, maktulün bu borcu tahsil amacıyla sanığa ulaşmaya çalıştı̆̆ , çeşitli vesilelerle oyalanan maktulün olay günü sanığın evine giderek sanıktan ısrarlı bir şekilde borcunu istediği, aralarında tartışma yaşandığ 1 , sanığın elindeki tabancayla maktulü uzak atış mesafesinden öldürdüğü olayda; ilk haksız hareketin hangi taraftan geldiğinin kesin olarak tespit edilemediği, bu nedenle sanık lehine haksı tahrik hükümlerinin en asgari seviyede uygulanması gerektiği gözetilmeden sanık hakkında eksik ceza tayini, bozmayı gerektirmiştir", 1. CD, 20.02.2019, E. 2017/2256, K. 2019/1015.

152 Dönmezer/Erman, C. II, s. 111; Koca/Üzülmez, Genel Hükümler, s. 279; Zafer, s. 378.

153 Örnek için bkz.: Demirbaş, s. 342.

154 "Sanığın sahibi bulunduğu kampta, babasının sponsor olduğu festivale katılan maktulün, kamptan ayrılırken aracının park edildiği yer sebebiyle işyeri çalışanları N. ve S.' la tartışma yaşadığ ${ }_{1}$, hatta güvenlik görevlisi olan S.'1 tehdit edip, darp ettiğii, maktulün arkadaşı katılan L.'in araya girmesi sonrasında olay sona erip, maktulün kamptan ayrıldığı göz önüne alındığında bu olay sebebiyle sanık hakkında meşru savunma şartlarının oluştuğundan söz edilemeyecektir. Zira haksız olduğu düşünülen saldırı sona erdiğinden, savunmanın saldırı ile eş zamanlı olması şartı gerçekleşmemiştir. Kamptan ayrıldıktan kısa süre sonra, babasına ait tıra ve tırın şoförüne saldırıldığı bilgisi üzerine tekrar kampa gelen maktulün, olay sırasında sanık ve yanındakilere doğru ateş etmesi, hatta yerden seken kurşunlar sebebiyle sanıkla tanıklar N. ve D. D.'ın yaralanmış olması nedeniyle, sanı̆̆ın kendisini ve yanındakileri korumak amacıyla maktule ateş ettiği, dolayısıyla meşru savunma şartlarının gerçekleştiği düşünülebilir ise de, maktulün meşru savunmayı gerektirecek şekilde haksız bir saldırıda bulunmadığı, aksine sanık ve adamlarının kendisine doğru yöneldiğini görünce, kendisine ve arkadașı L.'e zarar vereceklerini düşünerek, kendisini ve arkadaşını korumak ve sanıkla yanındaki kalabalık grubu uzak tutmak amacıyla üzerinde taşıdığı ruhsatlı silahını çıkarıp yere doğru ateş ettiği, bu durumun sanığın işyerinde çalışan ve önceki olayda maktül tartı̧̧ma yaşayan tanık N. tarafından, “...Fakat hiçbir şekilde kalabalığa doğru silahı doğrultmadı. Kalabalık dağılsın diye yahut ta korkudan yere doğru ateş etti. Kimseyi yaralamayı düşün- 
aşılması gerekmektedir. Sınırın kast veya taksirle aşılmasının önemi yoktur. Buna karşılık sınırın heyecan korku veya telaştan (asthenische Affekte) değil

düğünü zannetmiyorum. Bu sırada yere doğru ateş ederken yerden seken kurşunlar beni yaraladı" şeklindeki anlatımla da doğrulandığı anlaşılmakla; sanık ve yanındaki grubun kendisine ve arkadaşına zarar vereceği düşüncesiyle, kendisi ve arkadaşını korumak amacıyla üzerlerine doğru gelen ve içlerinden sanığın da bulunduğu grubu doğrudan hedef olarak ateş etmesi imkân dâhilinde iken yere doğru ateş eden maktülü, savunmayı gerektirecek bir saldırı olmaksızın kasten öldüren sanık hakkında meşru savunma şartları oluşmadığı gibi, meşru savunma kapsamında değerlendirilebilecek bir savunmanın varlığından söz edilemeyeceğinden, T.C.K.nun 27/2. maddesi kapsamında meşru savunmada sınırın aşılması hali de söz konusu edilemez. Kendisine ve yanında bulunanlara yönelmiș bir saldırı olmaksızın eylemini gerçekleştiren sanığın, işyeri çalışanları N. ve S.' 'la tartışan ve akabinde S.'1 tehdit edip, darp eden maktüle karşı önceki olay sebebiyle duyduğu öfke ve kızgınlıkla haksız tahrik altında eylemi gerçekleştirdiğinin kabulü gerekmektedir. Bu nedenle, sanığın haksız tahrik altında kasten öldürme suçundan cezalandırılmasına dair yerel mahkeme hükmü usul ve yasaya uygun olup, bu hükmü onayan Özel Daire kararında da bir isabetsizlik bulunmamaktadır", CGK, K.T. 11.06.2013, E. 2013/1-295, K. 2013/295. Kararın bir kaç açıdan değerlendirilmesi gerekmektedir. Öncelikle ilk atışı yapan kişinin eyleminin ceza hukuku açısından açıklığa kavuşturulması gerekir. Olayda kendilerine saldıracaklarını düşünerek saldırıyı gerçekleştirmişse, ancak bir saldırı gerçekte yoksa hukuka uygunluk sebeplerinin maddi şartlarında hata hükümlerinin uygulanması gerekir. Çünkü sınırın aşılması oranda sınırın aşılmasında uygulanmakta, zamanda sınırın aşılmasında geçerli olmayıp, hukuka uygunluk nedenlerinin maddi şartlarında hata bulunmaktadır. Hataya düşmesinde taksiri varsa taksirli sorumluluk söz konusu olabilecektir. Bu hata heyecan, korku veya telaştan kaynaklanmış olsa da yine hukuka uygunluk nedenlerinin maddi şartlarında hata hükümleri çerçevesinde değerlendirmek gerekir. Ancak olayda maktule doğru gelen grup saldırı için yürüyorsa, yani saldırı muhakkak ise bu takdirde meşru savunma söz konusu olacak ve meşru savunmada sınırın aşılması devreye girecektir. Maktulün yere ateş etmesinde ve kurşunun sekmesinde 27. maddenin 1. fikrasına giren bir durum söz konusudur. Fail içinde bulunduğu heyecan korku telaş nedeniyle yapmas1 gerekenin ötesine geçmişse 27. maddenin 2. fikrasına giren bir durum mevcuttur. Karara konu teşkil eden olayda yaralamaya neden olan kişinin eylemi sınırın aşılması kapsamında ve dolayısıyla haksızlık teşkil eden bir fiil söz konusudur (TCK m. 27). Olayda buna ilişkin belirleme yapılmamıştır. Ceza Genel Kurulu olayda bu fiilin meșru savunmayı gerektirecek haksız bir saldırı olmadığını ifade etmektedir. Olayda haksız bir fiil olduğu anlaşılmakla birlikte sorun meşru savunmanın bulunup bulunmadığına ilişkindir. Olayda sanığın yaptığı öldürmeye yönelik kasıtlı davranışının meşru savunma kapsamında değerlendirilmeyeceğidir. Maktulün tartıştı̆̆ kişinin ifadesinden de anlaşıldığ gibi engel olunmak istenmesine rağmen öldürmek için hareket etmektedir. Söz konusu tanık ifadesinde, "Genç çocuk dişarıya çıktı. O da bağırıyordu. Biz gayri ihtiyari adama doğru yürüdük. Bu sırada B.'la D. tartışıyordu. Araçta bulunan kişi da arabadan indi. Daha sonra genç çocuk belinden silahını çıkarttı. Tabancasıyla yere doğru ateş etti. Ancak çok sayıda ateş etti. Fakat hiçbir şekilde kalabalığa doğru silahı doğrultmadı. Kalabalık dağılsın diye yahut da korkudan yere doğru ateş etti. Kimseyi yaralamayı düşündüğünü zannetmiyorum. $\mathrm{Bu}$ sırada yere doğru ateş ederken yerden seken kurşunlar beni yaraladı. Ben yere düştüm. Bunun üzerine B. bey tabancayı çocuğa doğru doğrulttu. Çocuğun yanındaki sakallı kişi B. beyin üzerine atladı ve silahı B.'dan almak istedi. Ancak o sırada tabanca ateş aldı ve sakallı çocuk yaralandı. Hem B. hem de sakallı yere düştüler. Bu esnada B. da tabancayı D.'a doğrultmuştu ve ateşledi”" şeklinde belirleme yapmıştır. Olayda Ceza Genel Kurulu kararının sonuç olarak doğru olduğu anlaşılmaktadır. 
de saldırıdan kaynaklanan öfke ve gazabın (sthenische Affekte) etkisiyle aşılması halinde ${ }^{155}$ 27. maddenin 2. fikrası uygulanmayacak ${ }^{156}$, haksız tahrik

155 "harp sanatını öğrenmek ve yapmak mükellefiyeti olarak tanımlanan askerlik görevini yaklaşık 10 aydır olayın meydana geldiği kıtasında yapmakta olan sanığın, görevini etkili bir biçimde yerine getirmesi için kendisine verilen fiziksel, psikolojik ve ahlaki eğitim ile nöbete, silah kullanmaya, sınır ihlali yapan kişilere karşı davranış şekillerine ilişkin talimatlar hilafına hareket ettiği, elinde veya üzerinde herhangi bir silah bulunmadığı sabit olan maktulün kendisini askerlere ihbar ettiğini düşündüğü tanık ..........'ye kızarak üzerine doğru koşması ve sanığın maktule yumrukla vurarak yere düşürmesi üzerine de yerden kalkarak sanığın üzerine hızla yürümekten ibaret eylemlerinin, sanığa veya olay yerinde bulunan kendisine yönelik silahsız etkili eyleme karşı savunma yapabilecek fiziksel yapıya sahip 18 yaşındaki tanık .....'a yönelmiş ciddi ve haksız bir saldırı oluşturmaması karşısında; sanığın saldırıyı o andaki hâl ve şartlara göre saldırı ile orantılı biçimde defetmek zorunluluğu ile hareket etmeyip haksızlık karşısında öfkeye kapılarak son derece orantısız şekilde tepki gösterip tüfeğinin ucuna takılı süngüyü maktulün göğsüne saplayarak haksız tahrik altında maktulün ölümüne yol açtığı anlaşıldığından, sanık hakkında meşru savunma veya meşru savunmada sınırın aşılması hükümlerinin uygulanma imkânının bulunmadığının kabulü gerekmektedir”, CGK, 05.02.2019, E. 2015/1-705, K. 2019/59.

156 Özgenç, Türk Ceza Hukuku, s. 459; Mitsch, s. 103; Tröndle/Fischer, § 33, kn. 4. "Oluşa ve dosya kapsamına göre; mağdurun sanığa tekme tokat atmasının ardından sanığın yanında taşıdığı meyve soymak için kullandığı bıçakla mağdura saldırarak mağduru sağ ve sol göğüs kafesinden, göğüs boşluğuna nafiz sol hemopnömotoraksa ve sağ pnömotoraksa neden olup, mağdurun hayati tehlike geçirmesine sebep olacak şekilde yaraladığı olayda; sanığın haksız tahrik etkisi altında kasten öldürmeye teşebbüs suçundan cezalandırılması yerine yazılı şekilde meşru müdafaada sınırın korku, telaş ve heyecanla aşılması sebebiyle ceza verilmesine yer olmadığına karar verilmesi, bozmayı gerektirmiştir”, 1. CD, 14.10.2019, E. 2019/1669, K. 2019/4281. 
hükmü ${ }^{157}$ geçerli olacaktır ${ }^{158}$. Hukuka uygunluk nedenlerinde sınırın aşılması durumunda aşılan kısım haksızlık teşkil ettiği için buna karşı meşru savunma mümkündür. Kusurluluğu ortadan kaldıran veya azaltan nedenlerde de haksız saldırı söz konusu olduğu için meşru savunma mümkündür. Örneğin eşinin kendisini aldattığını gören kişinin bunun etkisiyle eşini öldürmek için yaptığ 1 hareket için (haksız tahrik etkisiyle) öldürülmek istenen eş meşru savunmada bulunabilir.

Hukuka uygunluk nedeni içinde hareket eden kişi hataya düşmemekle birlikte saldırıda bulunan kişi dışında başka bir kişiye veya saldırganla birlikte başka birine karşı harekette bulunmuş ve zararlı bir sonuç meydana getirmişse, yani somut olayda sapma gerçekleşmişse kişi savunmada bulunduğu kişi dışında diğer kişi açısından da meşru savunmadan yararlanacak mıdır? Bir görüşs sapma durumunda da failin hukuka uygunluk nedeninden

157 "Maktul ve mağdurlar öncelikle Ersin'in vücut bütünlüğüne yönelik bir saldırıda bulunmuşlar, Ersin'in bağırarak yardım istemesi nedeniyle sanık Fatih'in olay yerine gelmesi üzerine de, bu saldırıyı "Fatih'e" yöneltmişlerdir. Sanık Fatih'e yönelik saldırı, maktul tarafından "bıçakla", mağdurlar tarafından ise "taşlar ve mermer parçaları ile" yapılmıştır. Burada maktul ile mağdurlardan gelen ve "sanığın yaşam hakkına veya en azından vücut dokunulmazlığına" yönelen haksız bir saldırı bulunmakta ve devam etmekte ise de; sanık Fatih'in girdiği mücadele sonunda Ayhan'ın elindeki bıçağı almasının ardından, maktul ve mağdurların saldırıları durmuş, fakat sanık olaydan kaynaklanmış bile olsa arkadaşının yaralanmasından duyduğu üzüntünün ve kendisine karşı yapılmış ve bitmiş olan saldırının kızgınlığı ile maktul ile mağdurları bıçakla yaralamış, eline geçirdiği bıçakla maktulün önce sağ karın kısmına vurarak karaciğer sağ alt lobunu, bununla da yetinmeyerek bıçağı yukarı doğru hareket ettirerek sağ diyaframayı parçalayarak, ölüme neden olmuştur. Bu şekilde gerçekleşen olayda üzüntü ve kızgınlığın etkili olduğu, dolayısıyla, ağır düzeydeki haksız tahrik altında işlenmiş kasten öldürme ve kasten yaralama suçlarından bahsedilebilirse de, mazur görülebilecek bir korku, panik ya da heyecanın tesirinden söz edilemeyeceğinden, 5237 sayılı TCY'nın 27. maddesinin 2. fikrasının uygulanma koşullarının oluştuğu söylenemez", T. 05.10.2010, E. 2010/1-170, K. 2010/182. "Her iki tarafın da yanlarına öldürmeye elverişli silahları alarak olay yerinde buluşmaları, sanık ...'ın araçtan inerken yanına tabancasını da alması, kavga ortamında elindeki sopanın düşmesiyle birlikte tabancasını çekerek babası Halis'le kavga eden mağdur ...'ye birkaç kez ateş etmesinin ardından, üzerine doğru bir elinde sopa, diğer elinde bıçakla gelmekte olan maktulü hayati olmayan bölgelerine ateş ederek bertaraf etme imkânı varken maktulün hayati bölgelerini hedef alması ve ilk atışla birlikte yere düşüp tehlikeliliği ortadan kalkmasına rağmen maktule yakın mesafeden birkaç kez daha ateş etmesi hususları birlikte değerlendirildiğinde, sanık ...'1n kasten öldürme eylemini meşru savunma şartları altında gerçekleştirmediği ve meşru savunma kapsamında değerlendirilebilecek bir savunma bulunmadığı kabul edilmelidir. Bu nedenle, sanığın haksız tahrik altında kasten öldürme suçundan cezalandırılmasına ilişkin yerel mahkeme hükmü usul ve kanuna uygun olup, bu hükmü onayan Özel Daire kararında da bir isabetsizlik bulunmamaktadır", CGK, 31.10.2017, E. 2017/841, K. 2017/440.

${ }^{158}$ Eleştiri ve 27/2'nin uygulanabileceğine ilişkin olarak bkz.: Özbek/Doğan/Bacaksız, Genel Hükümler, s. 408. 
yaralanacağını kabul etmektedir ${ }^{159}$. Ancak burada sapma nedeniyle kendisine hareketle müdahalede bulunulan kişiden kaynaklanan bir saldırı yoktur. Diğer görüş ise, sapma durumunda bir hukuka uygunluk nedeninin bulunmadığını, sapma sonucunda meydana gelen neticeler açısından kast veya taksire göre değerlendirme yapmak gerektiğini ve kast veya taksirine göre sorumlu tutmak gerektiğini ifade etmektedir ${ }^{160}$. Sapma sonucu gerçekleşen neticeler açısından kast veya taksirinin olacağı doğru olmakla beraber somut olayda saldırıdan başka türlü kurtulma olanağı yoksa, savunma hareketinin yapılması zorunluysa, sapma sonucu gerçekleşen netice açısından ise zorunluluk halinin şartları söz konusuysa fail hem meşru savunmadan hem de zorunluluk halinden yararlanır. Uygulanma imkânı olan herhangi bir neden yoksa kişi sapma sonucu gerçekleşen sonuçtan sorumlu olacaktır.

Kasten öldürme ilgilinin rızası açısından değerlendirildiğinde ölenin öldürülmesine rıza göstermesi fiili hukuka uygun hale getirmez. Zira yaşama hakkı, kişinin bir başkasının fiiline rıza göstermek şeklinde üzerinde serbestçe tasarruf edebileceği bir hak niteliğinde değildir. Hukukumuzda ötenazi kabul edilmediğinden bu kapsama giren fiiller öldürme suçu kapsamında değerlendirilecektir. Ötenazi, iyileşme imkânı bulunmayan hastalığı olan ve acı çeken bir kişinin acılarına son vermek amacıyla istemi üzerine hekim tarafindan hayatına son verilmesini ${ }^{161}$ ifade etmektedir ${ }^{162}$. Hasta Haklar1 Yönetmeliğinin 13. maddesine göre, "Ötenazi yasaktır. T1bbi gereklerden bahisle veya her ne suretle olursa olsun, hayat hakkından vazgeçilemez. Kendisinin veya bir başkasının talebi olsa dahi, kimsenin hayatına son

159 Dönmezer/Erman, C. II, s. 28; Özbek/Doğan/Bacaksız, Genel Hükümler, s. 306.

${ }^{160}$ Koca/Üzülmez, Genel Hükümler, s. 303, 304. Yazarlar zorunluluk halinin şartlarının oluşmuş olması şartıyla failin zorunluluk halinden yararlanacağını da belirtmektedirler.

161 Ötenazinin kim tarafından yapılacağı konusunda doktrinde tartışma yaşanmaktadır. Bir görüş herhangi bir kişi tarafından yapılacağını belirtirken, diğer görüş hekim tarafından yapılmasının gerektiğini belirtmektedir. Hekimin kabul edilmesinde tek hekimin mi, yoksa farklı uzmanlık alanlarında görevli hekimler kurulunun mu ötenaziye karar vereceği sorun teşkil etmektedir. Eğer ötenazi kabul edilirse hekim tarafından yapılacağının düzenlenmesi uygun olacak ve bu takdirde de farklı uzmanlık alanlarında çalışan hekimler kurulunun oybirliği ile karar vermesi gerekir: Centel/Zafer/Çakmut, Kişilere Karşı İşlenen Suçlar, s. 36. Ancak ötenazinin yargı kararıyla veya hekim kararılla uygulanabileceği belirtilmektedir. Yargı kararıyla gerçekleştiriliyorsa kazai ötenazi, hekim kararıyla yapılıyorsa medikal ötenazi kabul edilmektedir: Yaşar/Turan, s. 55.

${ }^{162}$ Hukuka uygun sayılıp sayılmaması konusunda farklı görüşler bulunmaktadır. Bunlar için bkz.: İçel/Sokullu-Akıncı/Özgenç/Sözüer/Mahmutoğlu/Ünver, s. 189. Talep üzerine öldürme ise, ötanaziden farklı olup, herkes tarafindan herhangi bir saikle talep edilmesi üzerine yapılan öldürme fiilidir. Bkz.: Yaşar/Turan, s. 43-45. 
verilemez". Dolayısıyla hastanın izdıraplarına son vermek nedeniyle bile olsa ölümün gerçekleştirilmesi hukukumuza göre kasten öldürme teşkil etmektedir. Ancak kişiye acıyarak bu fiilin gerçekleştirilmesi halinde TCK m. 62 anlamında takdiri indirim nedeni uygulanabilecektir ${ }^{163}$. Ancak doktrinde bazı yazarlar tarafından hastanın 1srarlı talebi ve onun çektiği acılara dayanamayarak hastanın öldürülmesi halinde kusurluluğu kaldıran bir neden olarak zorunluluk halinin uygulanabileceği belirtilmektedir ${ }^{164}$. Ancak belirtilen durumda zorunluluk halinin uygulanamayacağını, zira haklar bazında oranın bulunmadığını düşünüyoruz.

Ötenazi aktif ötenazi, pasif ötenazi ve dolaylı ötenazi olmak üzere 3'e ayrılmaktadır. Aktif ötenazide hastanın talebi üzerine aktif bir hareketle hastanın öldürülmesi söz konusudur. Kasten öldürme kapsamındadır. Pasif ötenazi, ölmek üzere olan hastanın talebi üzerine yaşamı uzatan tedbirlere son verilmesi ve tedbirlerin uygulanmamasını karşılamaktadır. Pasif ötenazi tedaviyi reddetme kapsamında kabul edilmekte ve doktorun sorumluluğunu doğurmamaktadır. Kişinin tedaviyi red hakkı kapsamında tedaviyi reddetmesi veya durdurması durumunda hekimin müdahalede bulunmaması suç teşkil etmeyecektir ${ }^{165}$. Ancak hastanın rizası olmadan bu yapıldığında doktorun ihmali şekilde öldürmeden sorumluluğu söz konusu olacaktır. Dolaylı ötenazi ise, doktorun hastanın acısını azaltmak amacıyla kullandığı ve kullanılmasına tıp biliminin izin verdiği ilacın, kaçınılmaz yan etkisi olarak hastanın yaşamının kısaltıldığı olaylar için ifade edilmektedir. Dolaylı ötenazinin cezalandırılmaması kabul edilmektedir. Bazı yazarlar bunun zorunluluk hali kapsamında cezalandırılmayacağını ifade ederken bazı yazarlar fiilin sosyal uygunluğu kapsamında, bazı yazarlar ise izin verilen risk veya yükümlülüklerin çatışması kapsamında cezalandırılmayacağını kabul etmektedirler ${ }^{166}$. Biz bu

${ }^{163}$ Hakeri, Tip Hukuku, (2019), s. 487.

164 Koca/Üzülmez, Özel Hükümler, s. 94.

165 Bilgilendirmenin yapılmış olmak ve karar verebilecek durumda olmak şartıyla hasta tedaviyi red edebilir. Hasta Hakları Yönetmeliğinin 25. maddesine göre, "Kanunen zorunlu olan haller dışında ve doğabilecek olumsuz sonuçların sorumluluğu hastaya ait olmak üzere; hasta kendisine uygulanması planlanan veya uygulanmakta olan tedaviyi reddetmek veya durdurulmasını istemek hakkına sahiptir. Bu halde, tedavinin uygulanmamasından doğacak sonuçların hastaya veya kanuni temsilcilerine veyahut yakınlarına anlatılması ve bunu gösteren yazılı belge alınması gerekir."

166 Hakeri, Tıp Hukuku, (2019), s. 488. Ötenazi başka ayrımlara da tabidir. Bunlardan biri de istemli ötenazi istemsiz ötenazidir. İstemli ötenazi de hasta olan kişinin iradesiyle ötenazi işleminin gerçekleştirmesi söz konusudur. Bu durumda ötanazinin hukuki sonuç doğurabilmesi için iradenin, karar verebilecek durumda olan kişinin iradesini hata, hile ve tehdide maruz 
durumda izin verilen riskin gerçekleşeceğini düşünüyoruz. Bazı ülkelerde aktif ötenazi talep üzerine öldürmenin alt şekli kabul edilmekte ve ötenaziyi uygulayan kişi talep üzerine öldüren kişi gibi cezalandırılmaktadır. Almanya (m. 216) ve Avusturya (m. 77) buna örnek olarak verilebilir. Bazı ülkeler ise ötenaziyi cezasızlık nedeni olarak görmektedirler. Peru CK, Belçika CK, Lüksemburg CK, Hollanda ${ }^{167}$ buna örnek olarak gösterilebilir ${ }^{168}$. Bazı ülkeler ise ötenaziyi kasten öldürme kapsamında nitelendirmektedirler. Fransa ve Türkiye bu kapsamda sayılabilir.

Talep üzerine öldürme, ötenaziden farklı anlamda kullanılmaktadır. Ötenaziden daha geniş bir kavramdır ${ }^{169}$. Ötenazi, talep üzerine öldürmenin bir görünüm şeklidir. Talep üzerine öldürme, mağdurun isteği üzerine, üçüncü kişi veya kişiler tarafından kişinin yaşamına son verilmesidir. Talep üzerine öldürmenin kasten öldürme suçu mu yoksa bağımsız bir suç mu sayılacağı konusunda farklı görüşler bulunmaktadır. Bazı ülkelerde talep üzerine öldürme ayrı bir suç olarak düzenlenmekte ve failin daha az cezayla cezalandırılması sonucunu doğurmaktadır ${ }^{170}$. Örneğin Alman CK m. 216 (6 aydan 5 y1la kadar) ve Avusturya CK m. 77'de (6 aydan 5 y1la kadar) cezanın 5 yıla kadar verilebildiği görülmektedir. İsviçre'de (m. 114, 3 yıla kadar hapis veya adli para cezas1) Portekiz CK'da (m. 134, 6 aydan 3 yıla kadar) 3 yıla kadar hapis cezasının uygulanabildiği görülmektedir ${ }^{171}$. Talep üzerine öldürmenin mağdurun acılarını dindirme amacıyla gerçekleştirilmesine gerek bulunmamaktadır. Psikolojik veya ekonomik sıkıntılardan kurtulmak veya aşk acısının verdiği üzüntüden bunalmak gibi nedenlerle öldürme talep edilebilir. Failin nedeni bilmesine de gerek bulunmamaktadır ${ }^{172}$. Önemli olan mağdurun ölmek isteği ve bu isteğinin fail tarafından gerçekleştirilmesinin ciddi, kesin ve 1 srarla talep edilmesidir ${ }^{173}$.

kalmadan açıklamış olması gerekmektedir: Alan-Akcan, s. 7, 8. İstemsiz ötenazide ise hasta iradesini açıklayacak durumda değildir (örneğin bitkisel hayat, koma, zihinsel kapalılık gibi). Hasta yakınlarının iradesiyle ötenazi işlemi gerçekleştirilmektedir.

${ }^{167}$ Ülkelerdeki düzenlemeler için bkz.: Yaşar/Turan, s. 45 vd.

168 Tezcan/Erdem/Önok, s. 192, 193.

169 Artuk, s. 19.

${ }^{170}$ Centel/Zafer/Çakmut, Kişilere Karşı İşlenen Suçlar, s. 37

${ }^{171} \mathrm{Bu}$ ülkelerle ilgili olarak bkz.: Yaşar/Turan, s. 63 vd.

172 Ekici-Şahin, s. 284.

${ }^{173}$ Bkz.: Centel/Zafer/Çakmut, Kişilere Karşı İşlenen Suçlar, s. 38; Ekici-Şahin, s. 284. 
AİHM ötenaziyi yasaklayan düzenlemelerin Sözleşmeye aykırı olmadığını kabul etmektedir. Mahkemeye göre devlete ölüm hakkını tanımak veya kolaylaştırmak gibi bir yükümlülük yüklenemez. Ancak ötenaziyi kabul etmenin de Sözleşmeye aykırı olduğu anlamına gelmediği belirtilmektedir. Hastal1kları sebebiyle intihar edebilecek durumda olmayan kimsenin hayatına son verilmesine yardımcı olmak isteyen bir başka kimsenin cezalandırılmasının Sözleşmenin 2. maddesine aykırı olmadığı ifade edilmiştir ${ }^{174}$.

\section{TEŞEBBÜS}

Kasten öldürme suçunun oluşması için ölüm sonucunun gerçekleşmesi gerekir. Fail icra hareketlerine başlamakla beraber ölüm sonucunun gerçekleşmediği hallerde fiil teşebbüs aşamasında kalmıştır. Bu halde 35. madde gereğince teşebbüs hükümlerine göre sorumluluk tayin edilecektir. Olası kastla öldürme açısından teşebbüsün ${ }^{175}$ mümkün olup olmadığı tartışmalıdır ${ }^{176}$. Teşebbüsün mümkün olduğunu kabul eden yazarlar olduğu gibi ${ }^{177}$ bizim de görüşlerine katıldığımız bazı yazarlar aksini savunmaktadırlar ${ }^{178}$. Yargıtay

\footnotetext{
174 Tezcan/Erdem/Önok, s. 194.
}

175 Yargıtay bir kararında olayla ilgisi olmayan kişinin isabet aldığı, faillerin olası kastla hareket ettiği, ancak kurşunun kimin silahından çıktığının belirlenemediği olayda olası kastta teşebbüsü kabul etmediğinden beraat yönünde karar vermiştir: "Dava; kasten öldürme ve kasten öldürmeye teşebbüs suçlarına ilişkindir. Sanıklar ile suça sürüklenen çocuğun fikir ve irade birliği içinde tabanca ile olay yerine gelip fiil üzerinde ortak hakimiyet kurduğu, diğer sanıkların yanlarındaki tabancalarla maktule ve mağdura ateş etmelerinden sonra, yine onlarla birlikte olay yerinden kaçıp tanığın aracıyla eve gittiği ve burada yakalandığı, sol el üstünden alınan svapta atış artığı tespit edildiği, sanıkların ateşi sonucu maktulün sağ göğüs, mağdurun sol tibia, olayla ilgisi bulunmayan mağdurun ise sağ ayak bölgesinden hangi sanığın ateşiyle isabet aldığı anlaşılamayacak şekilde yaralandığı olayda, Sanığın maktulü kasten öldürme, mağduru öldürmeye teşebbüs suçlarından TCK'nun 37/1 maddesi uyarınca sorumlu tutulması gerekir. Suça sürüklenen çocuğun suç tarihinde onbeş-onsekiz yaşları arasında olması sebebiyle TCK'nun 31/3 maddesine göre onbeş yıl hapis cezası tayin edildikten sonra, diğer cezalara dair olan ve bu hallerde verilecek cezayı oniki yıl ile sınırlayan aynı maddenin son cümlesinin uygulanamayacağı gözetilmelidir. Sanıklar ve suça sürüklenen çocuğun hedefinde olmayan mağdurun hangi sanığın eylemi sonucu yaralandığını tespit etmek mümkün olmadığından, sanıkların mağduru olası kastla yaralama suçlarından mahkumiyetlerine yeterli delil bulunmadığ 1 kabul edilerek beraatlerine karar verilmesi gerekir", 1. CD, 22.01.2018, E. 2016/5744, K. 2018/115.

176 Bkz.: Sözüer, s. 162 vd.

177 Sözüer, s. 164; Öztürk/Erdem, s. 354; Önder, C. II-III, s. 398; Özbek/Bacaksız/Doğan, Genel Hükümler, s. 271.

${ }^{178}$ Artuk/Gökcen, Genel Hükümler, s. 337; Özgenç, Türk Ceza Hukuku, s. 498; Soyaslan, Genel Hükümler, s. 434. 
olası kastta teşebbüsü kabul etmemekle beraber ${ }^{179}$ aksine kararları da bulunmaktadir ${ }^{180}$.

Başarısız teşebbüs denilen ${ }^{181}$ olaylarda da fail teşebbüsten dolay1 sorumludur. Failin icra hareketlerine başladıktan sonra elindeki mevcut araçlarla fiili gerçekleştirmeyeceğini anlaması veya hatalı olarak öyle kabul etmesi olaylarında başarısız teşebbüs vardır. Keza failin fiili gerçekleştirme yeteneğinin ortadan kalkması veya suçun konusunun bulunmaması durumlarında da başarısız teşebbüs gerçekleşebilir. Örneğin icra hareketlerine başlayan failin aracın elverişsiz hale gelmesi nedeniyle fiili işleyememesi halinde başarısız teşebbüs vardır. Örneğin kurşunlarının bitmesi veya silahının bozulması nedeniyle failin icra hareketlerini tamamlayamaması halinde öldürmeye teşebbüsten sorumluluk tayin edilecektir. Keza bombanın patlamaması nedeniyle fiilin tamamlanamaması halinde fail öldürmeye teşebbüsten sorumlulu olacaktır. Mağdurun kaçması nedeniyle ölümün gerçekleştirilememesi durumunda vazgeçme söz konusu olmayıp ${ }^{182}$, fail teşebbüsten dolayı sorumlu tutulacaktır. Hareketin hedefinin fail açısından tamamen anlamsız olduğu hallerde de başarısız teşebbüs vardır. Mağdurun değişmesi nedeniyle fiilin gerçekleştirilmemesi halinde gönüllü vazgeçme söz konusu değildir ${ }^{183}$. İcra hareketleri başlamak şartıyla sorumluluk söz konusu olacaktır. Örneğin A'yı öldürmek isterken araya B'nin girmesi nedeniyle failin asıl hedeflediği kişiyi öldürememesi halinde teşebbüsten sorumluluk tayin edilecektir

Müşterek failliğin söz konusu olduğu hallerde teşebbüsün ne zaman başladığı doktrinde tartışmalıdır. İştirakin esasına uygun olması nedeniyle bizim de kabul ettiğimiz ve doktrinde hâkim olan bütüncül çözüm, faillerden birinin icra hareketlerine başlamasını yeterli kabul etmekte ve tüm faillerin teşebbüs aşamasına girdiğini benimsemektedir. Çünkü bu kişiler arasında birlikte suç işleme kararı bulunduğu için her katılana diğerinin fiili de isnat edilecektir $^{184}$.

${ }^{179}$ CGK, 27.12.2005, E. 2005/1-131, K. 2005-167; CGK, 19.12.2017, E. 2014/8-414, K. $2017 / 554$.

${ }^{180}$ Bkz.: Koca/Üzülmez, Genel Hükümler, s. 180, 181.

${ }^{181}$ Başarısız teşebbüs için bkz.: Gropp, s. 330, 331.

182 Schönke/Schröder-Eser, § 24, kn. 9.

183 Tröndle/Fischer, $\S 24$, kn. 8.

${ }^{184}$ Bkz.: Schönke/Schröder-Eser, § 22, kn. 55, 55 a. 
Dolaylı faillikte de teşebbüsün başladığı zaman tartışmalıdır. Biz bu konuda bütüncül çözümü kabul etmekte ve dolaylı fail için de teşebbüsün, aracı olarak kullanılan kişinin doğrudan doğruya icraya başladığ 1 andan itibaren söz konusu olacağını ifade etmekteyiz ${ }^{185}$. Bu nedenle dolaylı faillikten ve sorumluluğundan söz edebilmek için araç olarak kullanılan kişinin öldürme suçunun icra hareketine başlaması, yani teşebbüsün gerçekleşmesi gerekmektedir.

Ceza hukukunda şerikler suçun icra hareketini gerçekleştirmemektedirler. Bir başka ifadeyle onlar suçu işlememektedirler. Failin fiilinden dolayı bağlılık kuralı gereğince sorumlu olduklarından icra hareketlerinin başladığı zaman şeriklerin hareketine göre belirlenmez. Failin hareketi icra hareketi için belirleyicidir ${ }^{186}$. Dolayısıyla öldürme suçunda icra hareketi faile göre belirlenecektir.

Fiilin teşebbüs halinde kalmasına tamamlanmış şekline oranla daha az ceza verilmektedir. Bunun nedeni suçun objektif unsurunun tamamlanamamas1 nedeniyle tamamlanmış suça göre haksızlık içeriğinin az olmasıdır. Cezanın nasıl tespit edileceği 35. maddede belirtilmiştir. Teşebbüse ilişkin norm tek başına uygulanan bir hüküm olmadığ hallerde o suçun düzenlendiği kanuni tanıma bağlı olarak uygulanma niteliğine sahip olduğu için, suçun tamamlanmış şeklindeki ceza üzerinden 35. maddenin 2. fikrasında belirtilen şekilde indirim yapılacaktır. Maddede belirtilen oranlar arasında ceza belirlemesi yapılırken meydana gelen zarar veya tehlikenin ağırlığı göz önüne alınacaktır. Örneğin öldürmeye teşebbüste mağdurun hayati tehlike geçirmesi ve uzun süre yoğun bakımda kalmasıyla, bu nitelikte olmayan öldürmeye teşebbüste verilecek ceza aynı olmayacaktır. Hâkim meydana gelen zarar veya tehlikenin ağırlı̆̆na göre asgari ve azami hadler arasında belirtilen oranlar arasında cezayı belirleyecektir. Teşebbüs durumunda hâkim, önce TCK'nın 61. maddesindeki cezanın belirlenmesindeki ölçütlere göre temel cezayı belirleyecek, bundan sonra 61. maddedeki sıray1 takip ederek teşebbüs hükmünü uygulayacak, bu hükmü uygularken de somut olayda ortaya çıkan zarar veya tehlikenin ağırlığını dikkate alarak teşebbüse ilişkin hükümde belirtilen sınırlar arasında bir ceza tayin edecektir ${ }^{187}$.

\footnotetext{
${ }^{185}$ Dolaylı faillikte teşebbüs için bkz.: Schönke/Schröder-Eser, § 22, kn. 54, 54 a; KKOWiGRengier, § 13, kn. 27.

${ }^{186}$ LK-Hillenkamp, Vor $\S 22$, kn. 131.

${ }^{187}$ CGK, 23.06.2009 gün ve 8-175, İlhan/Erel/Fazla/Örer/Çakı1/Köse/Halitoğlu/Bozoğlu/Kurşun/ Kir, s. 189.
} 
Öldürme suçu için icra hareketlerine başlayan fail icra hareketlerini tamamlamaktan gönüllü olarak vazgeçer veya icra hareketlerini tamamlamasına rağmen kendi çabalarıyla suçun tamamlanmasını veya neticenin gerçekleşmesini önlerse gönüllü vazgeçmeden yararlanır. Bu takdirde öldürmeye teşebbüsten değil, tamam olan kısım esasen bir suç oluşturduğu takdirde, sadece o suça ait ceza ile cezalandırılır. Örneğin mağdur ölmemiş, ancak yaralanmışsa kasten yaralamadan, herhangi bir şekilde ateş etmeden vazgeçmişse, ruhsatsız silah taşımaktan ve ruh sağlı̆̆ bozulmuşsa kasten yaralamadan sorumlu olacaktır ${ }^{188}$. Tek bir kişinin işlediği suçlarda TCK m. 36 gereğince gönüllü vazgeçme hükümleri uygulanacak, iştirak halinde işlenen suçlarda ise 41. madde gereğince gönüllü vazgeçme belirlemesi yapılacaktır.

\section{V. İSTIRAK}

Öldürme suçu iştirak halinde işlenebilir. Müşterek faillik, dolaylı faillik, yan faillik ve şeriklik gerçekleşebilir. Müşterek faillikte işlenen fiil her bir müşterek faile isnat edildiğinden her biri fail olarak işlenen suçtan sorumlu tutulmaktadır ${ }^{189}$. Öldürme neticesinin kimin fiilinden kaynaklandığ 1

${ }^{188}$ Koca/Üzülmez, Özel Hükümler, s. 128, 129.

189 “Olay tarihinde 24 yaşında olan 1989 doğumlu sanık ...’ün, Ordu il merkezinde ikamet ettiği, hakkında kasten öldürme suçundan verilen mahkûmiyet hükmü kesinleşen inceleme dış1 sanık ... ile yakın arkadaş olduğu, maktul ... ve inceleme dışı diğer sanık ... ile de tanışıkl1ğının bulunduğu, maktul ... ve ...'in bir süre Ordu'da yaşadıktan sonra çalışmak için birkaç yıl önce Samsun iline yerleştikleri, maktulün olay tarihinden iki gün önce ...'in kullandığı araçla Samsun'dan, memleketi Ordu'ya ziyaret maksadıyla geldiği, ... ve maktul ...'in olay günü Ordu'da yaşadıkları dönemde tanışmış oldukları... ve sanık ... ile buluştukları, önce liman bölgesinde daha sonra ise Boztepe'de gün boyu içki içerek sohbet ettikleri, akşam saat 18.00 sıralarında il merkezine ...'in kullandığı araçla döndükleri, sanık ...'nın bira almak için ...'den aracı büyük bir marketin önüne çekmesini istediği, sanık ... ve maktul ...'in araçtan inerek markete girdikleri, ... ve ...' in ise aracın yanında, dışarıda bekledikleri, bu esnada olay yerinden geçen tanık ...' 'n önceden tanıdığ 1 ...'in fazlaca alkollü olduğunu görünce, çok içki içmemeleri yönünde...'e tavsiyede bulunduğu, marketten sanık ... ile birlikte çıkan maktul ...'in tanık ...' in bu uyarısına tepki göstererek işlerine karışmamasını söylediği, maktulle tar-

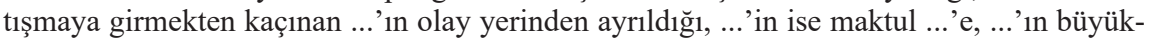
leri olduğunu, ...'la bu şekilde konuşmasının doğru olmadığını söylediği, bunun üzerine... ile maktulün tartışmaya başladıkları, maktulün...'e tokat atması ile kavga çıktığı, kavganın başladığını gören sanık ...'nın hemen maktulün arkasına dolanarak, maktulün kolunu geriye kıvırdığı ve eliyle ağzını kapattığı maktulün başını da geriye doğru çekip maktulü sıkıca tuttuğu, ...'in önce yumrukla daha sonra ise belinden çıkardığ baş ve omuz kısmına vurmaya başladığı, ardından da bıçağın kesici kısmı ile maktulün göğüs sağ kısmına bir kez şiddetle vurduğu, akciğerinden yaralanan maktulün darbenin şiddeti ile yere yığıldığ 1 , bu ana kadar maktulü hareketsiz kalacak şekilde sıkıca tutan sanık ...'nın maktulü bıraktığı, sanığın elinden kurtulan maktulün koşarak yakınlardaki bir iş yerine s1ğındığı, konuşma imkânı bulamadan kendinden geçen maktulün kaldırıldığı hastanede tüm tıbbi müdahalelere rağmen aynı gece, akciğer ve pulmoner ven kesisinden kaynaklanan iç 


\section{önemli değildir ${ }^{190}$. Sapma halinde de olası kastları bulunmak şartıyla kimin}

ve dış kanama sonucu hayatını kaybettiği, olay yerinden kaçan...'in ise sanık ... ile buluşarak gittiği barda, olaydan yaklaşık bir buçuk saat sonra sanık ile karşılıklı içki içerken suç aleti ile birlikte kolluk görevlilerince yakalandığı anlaşılan olayda; sanık ...'nın, hakkında kasten öldürme suçundan verilen mahkûmiyet hükmü kesinleşen ...'ın maktul ...'la kavgaya tutuştuğunu görmesi üzerine, ...'le birlikte o anda verdiği suç ișleme kararının icrası kapsamında, tereddüt etmeden derhâl arkasından dolanarak maktulün kolunu geriye büküp sıkıca tutması, diğer eli ile de maktulün yardım istemesini engelleyecek şekilde ağzını kapatması, bu şekilde...' in saldırısına karşı savunmasız bıraktığı maktulün olay yerinden kaçmasına engel olması, ...'in belinden bıçak çıkardığını görmesine karşın, maktulün kaçmasına ya da kendini savunmasına ve yardım istemesine engel olacak şekilde maktulün kolunu geriye kıvırıp ağzını kapatmaya devam etmesi, ...'in, maktulün göğüs bölgesine yönelik ölüme sebebiyet veren bıçaklı saldırısını tamamlamasından ve göğsünden yaralanan maktulün kendini yere bırakmasından sonra ancak maktulü serbest bırakması, olay yerinden kaçan... ile olaydan hemen sonra haberleşmelerinin ardından barda buluşması şeklinde, olay öncesinde, olay sırasında ve olay sonrasında sergilediği davranışlar birlikte değerlendirildiğinde; sanık ...'ün, yakın arkadaşı olan ve hakkında kasten öldürme suçundan verilen mahkûmiyet hükmü kesinleşen ... ile birlikte aldığı maktulü öldürme kararı çerçevesinde, fiil üzerinde ortak hâkimiyet kurarak maktul ...'in kasten öldürülmesi suçuna 5237 sayılı TCK'nın 37. maddesi kapsamında müşterek fail olarak katıldığı kabul edilmelidir”, CGK, 28.01.2020, E. 2017/1048, K. 2020/26; "Oluşa, tanık beyanlarına, kamera kaydına ve tüm dosya kapsamına göre; maktulün hakkındaki hüküm onanarak kesinleşen sanık. küfür etmesi nedeniyle başlayan tartışmanın kavgaya dönüştüğü, kavg sırasında sanıklar .,.,. maktule tekme ve yumruklarla vurduğu, tanık beyanlarına ve görüntülere göre adeta hepsinin "yumak" olarak maktulün direncini kırdıkları bir sırada. maktule dördü öldürücü olmak üzere yedi bıçak darbesi vurduğu, maktulün bu darbelere bağlı iç organ yaralanmasından gelişen iç kanama sonucu öldüğü anlaşılan olayda; Sanıklar . ve .maktulün direncini kırmak ve savunmasız hale getirmek suretiyle fikir ve eylem birliği içerisinde fiil üzerinde ortak hakimiyet kurdukları ve kasten öldürme suçunun müşterek faili olarak TCK'nın 37/1 maddesi uyarınca ayrı ayrı cezalandırılmalarına karar verilmesi gerektiği gözetilmeden, oluşa uygun düşmeyen gerekçeler ve yanılgılı değerlendirme sonucu basit yaralamadan dolayı şikayet yokluğu nedeniyle TCK'nın 73/4.ve CMK'nın 223/8. maddeleri gereğince düşme kararları verilmesi”, 1. CD, 5.5.2016, E. 2016/2710, K. 2016/2397.

190 “'Sanıkla.. ve ...'ın içerisinde bulunduğu grup bir tarafta, maktul ..., mağdurlar ..., ve...'nin arasında bulunduğu grup diğer tarafta olmak üzere suç mahallinde tarafların karşılaştığı, araçlarından önce ... ile maktulün inip konuşmaya başladıkları, sanık ...'in de içinde bulunduğu araçtan inerek maktulün yanına doğru geldiği ve elindeki bıçak ile ...'i yaraladığı, bu sırada olaya müdahale etmek isteyen maktulün arkadaşı mağdur ...'1 da aynı bıçak ile sol göğsünden biçaklayarak hayati tehlike geçirecek şekilde öldürmeye teşebbüs ettiği, tekrar maktule yönelerek toplam dört adet bıçak darbesi ile maktulü öldürdügüu, kavga sırasında sanık ...'nin elindeki silahla ateş ettiği ve bu ateş sonucu isabet alan ve olay yerine maktulle birlikte gelen mağdur ...'un basit tıbbi müdahale ile giderilemeyecek nitelikte yaraladığı, sanık ...'ın elindeki bıçakla sağa sola saldırdığı ve mağdur ...'ye bıçakla basit nitelikte yaraladığı, sanık...'ın ise aracın şoförlüğünü yaparak olay mahalline diğer sanıkları getirdiğí, suçun işlenmesi sırasında olay yerinde hazır olarak beklediği ve kavga bitince de aracı kullanarak sanıkların olay yerinden kaçmalarını sağladığı olayda; sanıkların olay mahalline kavga amaçlı hazırlıklı geldikleri, diğer sanık B. ile fikir ve irade birliği içinde hareket ederek ve dayanışmalı olarak maktulün öldürülmesi eylemi üzerinde ortak hakimiyet kurup suça müşterek fail olarak katıldıkları, sanık ...'1n elindeki bıçakla sağa sola saldırması şeklindeki tehdit suçunu oluşturduğu iddia edilen eyleminin de bir bütün halinde öldürme suçuna iştirak 
fiilin kaynaklandığ1 önemli olmaksızın müşterek failler gerçekleşen ölüm sonucundan sorumlu olacaklardır ${ }^{191}$. Kanun koyucu bazı suç tiplerinde suçun birden fazla kişi tarafından işlenmesini nitelikli hal olarak kabul etmektedir (TCK m. 102/3-d, 103/3-a, 106/2-c, 109/3-b, 119/1-c, 149/1-c, 265/3). Kasten öldürmede ise bu kabul edilmemiştir. Ancak İstanbul Sözleşmesi suçun, iki ya da daha fazla kişi tarafından birlikte işlenmesinin (m. 46/e) nitelikli hal olarak öngörülmesini istemektedir.

Öldürme fiili dolaylı faillik şeklinde de işlenebilir. Bu halde dolaylı fail kasten öldürmeden sorumlu olacaktır. Dolaylı fail öldürme için cebir tehdit kullanmışsa ayrıca cebir veya tehdit uygulamasından dolayı sorumlu olmaz. Arkadaki kişinin dolaylı fail olmasını sağlayan uyguladığı cebir veya tehdit olduğu için ayrıca bu fiillerden dolayı sorumlu tutulmaz. Kanun koyucu dolaylı faillik şekillerinden işlediği fiilin anlam ve sonuçlarını algılama yeteneği gelişmemiş olan veya ortadan kaldırılan kişilerin intihara sevk edilmesini ve cebir veya tehdit kullanmak suretiyle kişilerin intihara mecbur bırakılmasını TCK m. 84/4 düzenlemiş ve bu kişilerin dolaylı fail olarak sorumlu olacağını ifade etmiştir. Bunun dışındaki öldürme fiilinin dolaylı faillik şeklinde gerçekleştirildiği durumlarda fail 81. maddeden

suçu kapsamında değerlendirilmesi gerektiği, bu nedenle sanıkların TCK'nin 37 . maddesi delaleti ile maktulün öldürülmesi suçundan fail olarak sorumlu tutulup, sanık ... bakımından tahrik hususu da nazara alınarak cezalandırılmaları gerektiği gözetilmeden, yanılgılı değerlendirme sonucu beraatlerine karar verilmesi”, 1. CD, 6.2.2019, E. 2018/5276, K. 2019/529.

${ }^{191}$ Bkz.: "Olayımızda, sanıklar sabahki yaralama olayını bahane ederek, akşam tüfekleri ile olay yerine gitmişler ve ...'ı beklemeye başlamışlardır. Sanıklar iştirak halinde fikir ve eylem birliği içerisinde olay yerine gelmişlerdir. ...'ın komşusu ve akrabası mağdur ... ile olay yerine gelmesi üzerine ... evine girmiş, mağdur ... ise tarafları sakinleştirmeye çalışmıştır. Ancak bu konuda başarılı olamayınca ve ... da tüfekle evden çıkınca sanıklar iştirak halinde fikir ve irade işbirliği içinde arada kalan mağdur ...'ın da yaralanabileceğini öngörerek ...'a ateş etmişlerdir. $\mathrm{Bu}$ ateş sonucunda mağdur ... saçma taneleri ile alınan kati rapora göre hayati tehlike geçirecek şekilde yaralanmıştır. Sanıkların iştirak halinde tüfekleri ile olay yerine gelmeleri, birlikte tüfekleri ile olayları yatıştırmaya çalışan mağdur ...'in da yaralanabileceğini öngörerek tüfekle ...'a doğru ateş etmeleri sonucu, mağdur ...'1n saçma taneleri ile hayati tehlike geçirecek şekilde yaralanması olayında, sanıkların iştirak halinde olası kastla yaralama suçunu işledikleri belirlenerek yerel mahkemece sanıklar hakkında, TCK'nin 37/1. maddesi delaletiyle TCK'nin 86/1, 86/3-e, 87/1-d-son, 21/2, 62. maddeleri gereğince 2 yıl 1 er ay hapis cezası verilmiştir. Olay yerinde tek sanık olması halinde bu kişinin tüfekle ateş etmesi, araya giren kişinin yaralanması durumunda, olası kastla yaralanmanın kabul edildiği, ancak aynı olayda birden fazla sanığın tüfekle ateş etmesi durumunda "olası kasta iştirak olmaz" denilerek tüm sanıkların beraati yoluna gidilmesi usul, yasa, adalet ve hakkaniyete aykırı olacaktır, diğer taraftan aynı amaçla iştirak halinde fikir ve eylem birliği içinde olay yerine gelen birlikte tüfekle ateş eden, olası kastla yaralama suçunu işleyen sanıkların cezasız kalması durumu söz konusu olacaktır", 3. CD, 13.2.2020, E. 2020/377, K. 2020/2961. 
(suçun nitelikli hali gerçekleşmemişse-gerçekleşmişse 82. maddeden) dolaylı failliğe ilişkin TCK m. 37/2 gereğince sorumluluk tayin edilecek ve işlenen suçun cezasıyla cezalandırılacaktır. TCK'nın 37. maddesinin 2. fikrasının 2. cümlesinde ise, kusur yeteneği olmayanların suçun işlenmesinde araç olarak kullanılması durumunda dolaylı failin cezasının, üçte birden yarısına kadar artırılacağ 1 düzenlenmektedir. Bu düzenleme nitelikli hale ilişkin bir hüküm niteliği taşımaktadır. Bu düzenleme nedeniyle dolaylı failin cezası müşterek faile göre daha fazla olabilmektedir.

Kasten öldürme suçunda yan faillik de gerçekleşebilir. Birden çok kişinin aynı neticeye yönelik tipikliğe uygun davranışının olduğu ve bu kişilerin birbirinden bağımsız (habersiz) olarak hareket ettiği halleri ifade etmek için kullanılan yan faillikte her fail kendi yaptığı davranışa göre sorumlu olacaktır. Her ikisi de aynı anda öldürücü nitelikte isabet sağlamışsa her ikisi de öldürmeden, biri isabet ettirmiş ve mağduru öldürmüş, diğeri isabet etttirememişse, ölümü gerçekleştiren öldürmeden, diğeri öldürmeye teşebbüsten sorumlu olacak, kimin silahından çıktığı belirlenememişse her iki fail de öldürmeye teşebbüsten sorumlu olacaktır.

Şeriklik de mümkündür. Şeriklik ihmali hareketle gerçekleştirilebilir. Ancak bu yardım etme için geçerli olup, azmettirme için doğru değildir. İhmali hareketle azmettirme söz konusu değildir. Yargıtay bazı kararlarında müşterek failliği kabul etmediği olaylarda, fiilin işlendiği esnada olay yerinde bulunan ve failin yanında yer alan kişilerin eylemini yardım etme (suç işleme kararını kuvvetlendirme) şeklinde nitelendirmektedir ${ }^{192}$.

Şeriklerin sorumluluğu işlenen suça göredir (m. 38/1). Örneğin tek fiille 5 kişinin öldürülmesi için azmettirmede, eğer bu beş kişi de öldürülmüşse azmettiren 5 ayrı öldürmeye azmettirmeden sorumlu olacaktır. Azmettirenin sorumlu olabilmesi için sadece failin fiilinin suç teşkil etmesi yetmez, aynı zamanda azmettiren açısından da fiilin suç teşkil etmesi gerekir. Örneğin

\footnotetext{
192 'Eylemin asli faili olan suça sürüklenen çocuk ...'ın haber vermesi üzerine ona destek vermek ve kavga etmek amacıyla olay yerine gelen arkadaşları suça sürüklenen çocuklar .... ... ve ...'un üzerinde biçak olduğunu bildikleri suça sürüklenen çocuk ...'ın yanında kavgaya katıldıkları, ancak maktulün öldürülmesi eylemine TCK'nin 37. maddesi kapsamında müşterek fail sıfatıyla katıldıklarına ilişkin yeterli delil bulunmasa $\mathrm{da}$, olay sırasında asli fail olan arkadaşlarının yanında yer almak suretiyle onda mevcut olan suç işleme kastını kuvvetlendirdikleri, bu şekilde maktulün öldürülmesi eylemine TCK'nin 39/2-c maddesi kapsamında yardım eden sıfatıyla iştirak ettikleri nazara alınarak mahkumiyetlerine karar verilmesi gerektiği gözetilmeden yazılı şekilde beraatlerine karar verilmesi”, 1. CD, 15.04.2019, E. 2019/168, K. 2019/2254.
} 
kendisini öldürmesi için birini parayla tuttuğunda, o da fiili gerçekleştirmek için harekete geçip sonucu gerçekleştiremediğinde, öldürmeye teşebbüs eden kişi sorumlu olacak, buna karşın kendisini öldürmesi için para veren kişi azmettiren olarak sorumlu tutulamayacaktır. Azmettirenin cezası bazen failden daha fazla olabilmektedir. Üstsoy veya altsoy ilişkisinden doğan nüfuz kullanılmak suretiyle veya çocukların suça azmettirilmesi halinde azmettirenin cezası artırılmaktadır (m. 38/2).

TCK'nın 38. maddesinde (3. fikrasında) ayrıca cezayı ortadan kaldıran şahsi bir nedene yer verilmiştir. Buna göre azmettirenin belli olmaması halinde, kim olduğunun ortaya çıkmasını sağlayan fail veya diğer suç ortağ hakkında verilecek cezada indirim yapma imkânı tanınmıştır. Düzenlemede hükmolunabilir, yapılabilir ifadeleri yer aldığından indirim yapıp yapmama konusunda hâkimin takdir yetkisi bulunduğu anlaşılmaktadır.

Yardım eden kişinin iştirak nedeniyle sorumluluğu için suçun işlenmesine katkı yapmalıdır. Katkısının işlenen fiil açısından nedensel olması gerekir ${ }^{193}$.

Yardım eden kişi bir fiilde aynı zamanda azmettiren veya fail olabilir. Bu durumda azmettirmeden veya fail olmaktan dolayı sorumlu olacak, ayrıca yardım etme nedeniyle sorumluluğu yoluna gidilmeyecektir.

\section{VI. İÇTIMA}

Öldürme suçu zincirleme suç şeklinde işlenemez ${ }^{194}$. Çünkü zincirleme suçun varlığ için gerekli olan bir suç işleme kararının gerçekleşmeyeceğini düşünüyoruz. TCK m. 43/3 hükmü de öldürmede zincirleme suçu kabul etmemiştir. Yargıtay da ayni görüştedir. Yargıtay'a göre, "Sanık I ile karar ve eylem birliği içinde bulunan sanık F tarafindan 25.02.2004 tarihinde öldürülmeye teşebbüs edilmesinden dolayı hastanede tedavi altında bulunan maktulenin, 27.02.2004 tarihinde, sanık İ ile aynı karar ve eylem birliği içinde bulunan sanı $F$ tarafindan, yenilenen kasitla vurulup öldürülmesinde, araya giren zaman dilimi de gözetilerek, Yargıtay'ın yerleşik uygulamalarına göre, her iki suçun zincirleme (müteselsil) suç kabul edilemeyeceği gibi, esasen uygulanan 5237 Sayll Kanunun 43. maddesinin son fikrası uyarınca bu tür suçlarda bu madde hükümlerinin uygulanamayacağı düşünülmeden, sanık İrfan yönünden 765 sayıl TCK.nun 73. maddesinin de ayrıca tatbiki suretiyle her iki suçtan sanıklar hakkında ayrı ayrı ceza tayini gerekirken suçlara

\footnotetext{
193 Bkz.: Gropp, s. 392, 393.

194 Aksi görüş için bkz.: Koca/Üzülmez, Özel Hükümler, s. 132.
} 
zincirleme suç vasfi verilmesi" yasaya aykırıdır ${ }^{195}$.

Kasten öldürme suçunda fikri içtimanın gerçekleşmesi mümkündür:

Genel tehlike yaratan suçlar ile öldürme suçu fikri içtima halinde bulunabilir. Örneğin öldürme suçu, genel güvenliğin tehlikeye sokulması suçuyla farklı neviden fikri içtima halinde bulunabilir. Doğal anlamda birden fazla hareketle öldürme suçu ve genel güvenliğin tehlikeye sokulması suçu arasında fikri içtima kuralları Yargıtay tarafından uygulanmaktadır ${ }^{196}$. Aynı

${ }^{195}$ 1. CD, 16.11.2006, E. 2006/2398, K. 2006/4942.

196 “Sanık S.. Y..'nın eyleminin "kasten öldürme” suçunu mu yoksa “silahla ateş etmek suretiyle genel güvenliği kasten tehlikeye sokmak" suçunu mu oluşturduğu: 5237 sayılı TCK'nun 21/1. maddesine göre, suçun kanuni tanımındaki unsurlarının bilerek ve istenerek gerçekleştirilmesi olan ve failin iç dünyasını ilgilendiren kast, dış dünyaya yansıyan davranışlara bakılarak, daha açık bir ifadeyle failin olay öncesi, olay sırası ve olay sonrası davranışları ölçü alınarak belirlenmelidir. Kast, insanın iç dünyası ile ilgili bir kavram olduğundan, kastın açıkça ifade edilmediği durumlarda, iç dünyaya ait bu olgunun dış dünyaya yansıyan davranışlara bakılarak belirlenmesi yoluna gidilmektedir. Kişinin eyleminin, bir suçu oluşturup oluşturmadığının, oluşturuyorsa da hangi suçu oluşturduğunun tespiti için, eylemin bir aşamasındaki durumun değil, eylemin yapılması için verilen kararın, bu kararın icra ediliş biçiminin, olay öncesi, sırası ve sonraki davranışların da dikkate alınıp, tüm delillerin birlikte değerlendirilmesi gerekir. Öte yandan 5237 sayılı TCK'nun hazırlanmasında "kaç fiil varsa o kadar suç, kaç suç varsa o kadar ceza vardır" ilkesi esas alınmış, dolayısıyla da gerçek içtima kuralı benimsenmiştir. Nitekim Adalet Komisyonu raporunda bu husus; "Ceza hukukunun temel kurallarından birisi, 'kaç fiil varsa o kadar suç, kaç suç varsa o kadar ceza vardır' şeklinde ifade edilmektedir. Bunun istisnaları, suçların içtimaı bölümünde belirlenmiştir. $\mathrm{Bu}$ istisnalar dışında, işlenen her bir suçla ilgili olarak ayrı ayrı cezaya hükmedilecektir. Böylece verilen her bir ceza, bağımsızlığını koruyacaktır" şeklinde ifade edilmiştir (TBMM Adalet Komisyonu'nun 03.08.2004 gün ve 1/593-60 sayıl1 Raporu). Bu kuralın istisnaları ise, 5237 sayılı TCK'nun "suçların içtimaı" bölümünde, 42 (bileşik suç), 43 (zincirleme suç) ve 44. (fikri içtima) maddelerinde düzenlenmiştir.

765 sayılı TCK'da, aynı nev'iden fikri içtima ile farklı nev'iden fikri içtima tek madde halinde ve Kanunun 79. maddesinde düzenlenmiş iken, 5237 sayılı TCK'da bu iki hal birbirinden ayrılarak, aynı nev'iden fikri içtima, zincirleme suçun düzenlendiği 43 . maddenin 2. fikrasında, farklı nev'iden fikri içtima ise 44. maddesinde düzenlenmiştir. Farklı neviden fikri içtima 5237 sayılı Kanunun 44. maddesinde; "İşlediği bir fiil ile birden fazla farklı suçun oluşmasına sebebiyet veren kişi, bunlardan en ağır cezayı gerektiren suçtan dolayı cezalandırılır" şeklinde düzenlenmiş olup, hükmün uygulanabilmesi için işlenen bir fiille birden fazla farklı suçun oluşması gerekmektedir. Kanun koyucu, işlediği bir fiille birden fazla farklı suçu işleyen failin, fiilin tek olması nedeniyle en ağır ceza ile cezalandırılmasını yeterli görmüş, bu şekilde "non bis in idem" kuralı gereğince bir fiilden dolayı kişinin birden fazla cezalandırılmasının da önüne geçilmesini amaçlamış, "erime sistemi"ni benimsemek suretiyle, bu suçlardan en ağırının cezasının verilmesi ile yetinilmesini tercih etmiştir.

Bu bağlamda, "tek fiil" veya "bir fiil"den ne anlaşılması gerektiğinin de değerlendirilmesi gerekmektedir. Doğal anlamda gerçekleştirilen her bedeni hareket ayrı bir hareketi 
oluşturmakta ise de, hukuki anlamda hareketin tek olması ile ifade edilmek istenen husus, doğal anlamda birden fazla hareket bulunsa dahi, bu hareketlerin, hukuki nedenlerden dolayı değerlendirmede birlik oluşturması suretiyle tek hareket olarak kabulüdür. Fikri içtimada da, fiil ya da hareketin tek olması, doğal anlamda değil hukuksal anlamda tekliği ifade etmektedir. Bir kısım suçların işlenmesi sırasında doğal olarak birden fazla hareket yapılmakta ise de, ortaya konulan bu davranışlar suçun kanuni tanımında yer alan hukuki anlamdaki "tek bir fiili”" oluşturmaktadır. 5237 sayılı TCK'nun genel hükümleri arasında yer alan fikri içtima kuralları, şartların varlığı halinde bulunması halinde kural olarak her suç için uygulanabilir ise de, kanun koyucunun açıkça istisna öngördüğ̈̈ hallerde bu kuralın uygulanma ihtimali bulunmamaktadır. Nitekim TCK'nun 212. maddesinde, sahte resmi veya özel belgenin bir başka suçun işlenmesi sırasında kullanılması halinde, hem sahtecilik hem de ilgili suçtan dolayı ayrı ayrı cezaya hükmolunacağı belirtilerek, açıkça fikri içtima hükümlerinin uygulanması engellenmiştir. Görüldügü gibi, kanuni istisnalar dışında, hukuki anlamda tek bir fiille birden fazla farklı suçun işlenmesi halinde, bu suçlardan en ağır cezayı gerektirenin cezasına hükmolunması kanun gereği olup, suçların olası kastla veya doğrudan kastla işlenmiş olması da varılan bu sonucu değiştirmeyecektir. Kast ve fikri içtima ile ilgili bu açıklamalardan sonra kasten öldürme ve genel güvenliğin kasten tehlikeye sokulması suçları üzerinde durulmalıdır. Kasten öldürme suçu 5237 sayılı TCK'nun 81. maddesinde; "bir insanı kasten öldüren kişi, müebbet hapis cezası ile cezalandırılır," şeklinde, genel güvenliğin kasten tehlikeye sokulması suçu ise aynı kanunun 170. maddesinde; "(1) Kişilerin hayatı, sağlığı veya malvarlığı bakımından tehlikeli olacak biçimde ya da kişilerde korku, kaygı veya panik yaratabilecek tarzda; a) Yangın çıkaran, b) Bina çökmesine, toprak kaymasına, çığ düşmesine, sel veya taşkına neden olan, c) Silâhla ateş eden veya patlayıcı madde kullanan, Kişi, altı aydan üç yıla kadar hapis cezası ile cezalandırılır. (2) Yangın, bina çökmesi, toprak kayması, çığ düşmesi, sel veya taşkın tehlikesine neden olan kişi, üç aydan bir yıla kadar hapis veya adlî para cezası ile cezalandırılır" şeklinde düzenlenmiştir. Kasten öldürme suçu, mağduru öldürülen insan olan neticeli bir zarar suçudur. Ölüm neticesini meydana getirmeye elverişli herhangi bir hareketle suçun işlenmesi mümkündür. Bu suç ile korunan hukuki yarar kişinin "yaşama hakkı" dır. Suçun manevi unsuru genel kasttır. Genel güvenliğin kasten tehlikeye sokulması suçu ise seçimlik hareketlibir tehlike suçudur. TCK'nun 170. maddesinin birinci fikrasında, bu suçu oluşturan seçimlik hareketler, yangın çıkarmak; bina çökmesine, toprak kaymasına, çı̆̆ düşmesine, sel veya taşkına neden olmak; silâhla ateş etmek veya izinsiz patlayıcı madde kullanmak olarak sayılmış olup suç, somut tehlike suçu olarak düzenlenmiştir. Maddenin ikinci fikrasında ise, soyut tehlike suçu tanımına yer verilmiştir. Bu hükümde, yangın, bina çökmesi, toprak kayması, çığ düşmesi, sel veya taşkın tehlikesine neden olmak, ayrı bir suç olarak tanımlanmıştır. Buna göre bu fikrada düzenlenen suçun oluşabilmesi için somut bir tehlikenin meydana gelmesi gerekmemektedir. Genel güvenliğin kasten tehlikeye sokulması suçunun mağduru belirli bir kimse olmayıp toplumu oluşturan tüm bireylerdir. Bu suçla korunan hukuki değer, kişilerin hayat, vücut bütünlükleri ve mal varlığ 1 bakımından bir zarar tehlikesi doğmadan, güvenlik içerisinde yaşamaları üzerindeki haklarıdır. Suçla yasaklanan eylemlerin işlenmesi durumunda, kişilerin hayatları, sağlıkları veya mal varlıklarının zarar görmesi tehlikesi meydana gelmektedir. Tehlikenin somut olarak belirli kişi veya kişiler hakkında söz konusu olması gerekli olmayıp, belirsiz sayıda kişinin, dolayısıyla toplumu oluşturan birçok kimsenin bu suçtan dolayı korunması amaçlanmaktadır. Bu fiillerin işlenmesiyle bir zarar neticesinin meydana gelmesi hâlinde, meydana gelen zarara ve bu zararın meydana gelmesi açısından failin kast veya taksirine göre başka suçlar oluşacaktır. Örneğin, toplumda genel güvenliği tehlikeye sokan bir etki meydana getiren fiiller sonucunda bir veya birkaç kişi ölmüş veya yaralanmış ya da kişiler malvarlığı itibarıyla zarar görmüş olabilir. Bu gibi durumlarda, farklı neviden fikri içtima hükümlerinin uygulanması gerekir. Nitekim Ceza Genel Kurulunun 26.12.2006 gün ve 317- 
şekilde trafik güvenliğinin tehlikeye düşürülmesi fiiliyle kasten öldürme suçu fikri içtima ilişkisi içinde bulunabilir.

Sapma durumunda farklı neviden fikri içtima kuralları uygulanacaktır. Örneğin hedeflenen kişi dişında başka bir kimsenin kurşun sekmesi sonucunda öldüğü olayda, fail hakkında kasten öldürme suçuna teşebbüs ile taksirle öldürme suçu arasında farklı neviden fikri içtima kuralları gereğince sorumluluk tayin edilecektir.

Öldürme suçunda aynı neviden fikri içtima mümkün olmakla beraber TCK m. 43/3 nedeniyle aynı neviden fikri içtima kuralları uygulanmayıp, gerçek içtima kuralları gereğince sorumluluk tayin edilmektedir. Fiilin doğal anlamda tek olduğu hallerde bir sorun yaşanmamaktadır. Ancak doğal anlamda birden fazla hareketin olduğu ve birden fazla kişinin öldüğü olaylarda sorun yaşanmaktadır. Öldürme suçu üstün kişisel değer olan yaşam hakkını koruduğundan doğal hareket tekliği kapsamına giren hareketlerle birden çok kişinin öldürüldüğü (hedeflenin dışındaki kişiler için olası kastının

319 sayılı kararında da; “...5237 sayılı TCK'nun 170. maddesinde, 765 sayıl1 TCK'nun 264/7. maddesindeki düzenlemeden farklı biçimde eylemin bir başka suçu oluşturması halinde ayrıca cezalandırılacağına ilişkin bir düzenlemeye yer verilmemiştir. $O$ halde, eylemin aynı zamanda bir başka suçu da oluşturması halinde 5237 sayılı TCK'nun 44. maddesi uyarınca en ağır cezayı gerektiren suçtan cezalandırılması söz konusu olur" denilmek suretiyle, 5237 sayılı TCK'nun 170. maddesi bağlamında aynı kanunun 44. maddesinde düzenlenen farklı nevi'den fikri içtima kurallarının uygulanmasının mümkün olduğu, tereddüte meydan verilmeyecek bir biçimde ortaya konulmuştur. Bu açıklamalar 1şığında uyuşmazlık konusu değerlendirildiğinde; Olaydan yaklaşık bir buçuk yıl önce sanık Soner ile tanık Ufuk arasında başlayıp maktulün ve sanık Sercan'ın da dâhil olmasıyla büyüyen kavgada maktulün sanık Sercan'ı yaralamasıyla taraflar arasında husumetin başladığı, olay gecesi arkadaşlarıyla birlikte .... Restoran'a giden maktulün yolda sanık Sercan'a hakaret etmesi üzerine sanık Sercan'ın maktulü öldürmeye karar verdiği, sanıklar Sercan, Soner ve Umut'un restoran önünde bekledikleri, merdivenleri gözetledikleri, restoran çalışanlarının durumu fark ederek maktulü ve arkadaşlarını uyarmaları üzerine maktulün restoranın normal giriş çıkış kapısı yerine arka kapıya yöneldiği sırada sanık Sercan'ın restorana girip üzerinde taşıdığ $9 \mathrm{~mm}$. çapındaki silahla vestiyer kısmında bulunan maktulü hedef alarak 7-8 el ateş ettiği, ardından sanık Soner'in de sanık Umut'un elinden aldığ 7.65 mm.lik tabancayla restoranın çıkış merdivenini ateş altında tuttuğu, maktulün hastaneye ulaştırıldığ sırada öldüğü olayda; sanık Soner'in, Sercan'ın kasten öldürme eylemini gerçekleştireceğini bilmesine rağmen eyleme taraftar olmadığını gösterecek şekilde engelleyici herhangi bir davranışta bulunmaması, aksine olayın başından itibaren sanık Sercan'ın yanında yer alması, sanık Sercan'ın öldürme eylemi için restorana girdiği sırada restoran çalışanı tanık Çağrı'yı oyalaması, Sercan'ın eyleminden hemen sonra sanık Umut'un elindeki silahı alıp restoranın çıkışını ateş altında tutarak olay yerinden kaçmasına yardım etmesi, ardından sanık Sercan ile buluşup birlikte kaçması karşısında Sanık Sercan'ın kasten öldürme eylemine iştirak ettiğinin ve hukuken tek olan bu eylemi ile hem kasten öldürme hem de genel güvenliğin kasten tehlikeye sokulması suçlarını işlediğinin kabulü gerekmektedir”, CGK, 09.06.2015, E. 2013/713, K. 2015/203. 
bulunduğu) olaylarda fiil tekliği çoğunlukla kabul edilmemektedir ${ }^{197}$. Biz de bu görüşe katılıyor ve tek fiil de bile aynı nevi fikri içtimanın öldürme suçlarında kabul edilmediği sistemimizde (TCK m. 43/3) birden fazla doğal hareketle doğrudan veya olası kastla kişilerin öldürüldüğü olaylarda fiil tekliğinin ve fikri içtimanın uygulanmayacağını, gerçek içtimanın uygulanacağını düşünüyoruz. Yargıtay da verdiği bir kararda, "bu noktada; aralarında yer ve zaman bakımından sıkı bağlantı bulunmasına ră̆men doğal anlamda birden fazla hareketle, doğrudan veya olası kastla kişilerin yaşam hakkı ve vücut dokunulmazlığına yönelik hukuki menfaatlerin ihlal edilmesi durumunda fiilin hukuki anlamda tek olarak kabul edilip edilemeyeceği hususu üzerinde ayrıca durulmalıdır. Doğal anlamda birden fazla hareketin hukuki anlamda tek bir fiil olarak kabul edilip edilemeyeceği işlenen suçun özelliği de göz önüne alınarak yapılacak hukuki değerlendirme sonucunda belirlenmelidir. Bu bakımdan korunan hukuki menfaatler arasinda en üstte yer alan yaşam hakkı ve vücut dokunulmazlığına yönelik eylemlerde ĕger fail doğal anlamda birden fazla hareketle bir ya da birkaç kişiyi öldürmek ya da yaralamak amacıyla, öldürmek ya da yaralamak istediği kişinin yanında veya yakınında bulunan başka kişilerin de ölebileceğini veya yaralanabileceğini öngörmesine rağmen bunu göze alarak hareket ediyorsa artık ortada tek bir fiil değil, mağdur sayısinca birden çok fiil bulunduğunu kabul etmek gerekir. Ancak bunun için failin doğrudan ya da olası kastla hareket ettiğinin belirlenmesi gereklidir" şeklinde belirleme yapmıştır. Bu belirleme çerçevesinde de tek fiil olmadığından fikri içtima kurallarının (m. 44) uygulanamayacağını kabul etmektedir ${ }^{198}$. Ancak Ceza Genel Kurulu

${ }^{197}$ Ancak aksine belirleme yapan yazarlar da bulunmaktadır. Bkz.: Schönke/Schröder-Stree/ Sternberg-Lieben, Vorbem $\S \S 52$ ff., kn. 22, 23.

${ }^{198}$ CGK, 10.12.2013, E. 2012/1-1572, K. 2013/600. Yargıtay aynı yönde bir başka kararında "Sanığın, mağdur ...'e bıçakla saldırdığı, ancak onun yerine hedefte sapma sonucu yanında bulunan kardeşi maktul ...'i olası kastla öldürdüğ̈ kabul edilen somut olayda, mağdur ...'e bıçakla saldıran sanığın, kavgayı ayırmak amacıyla aralarına giren ve mağdurun yanında bulunan maktul ...'in ölebileceğini ya da yaralanabileceğini öngörmesine karşın, bunu göze alarak mağdura doğru birden çok biçak savurma şeklindeki eyleminin suçla korunan hukuki menfaatler göz önünde bulundurulduğunda hukuki anlamda tek fiil sayılması mümkün olmayıp, TCK'nun 44. maddesinin uygulanma şartları oluşmadığı, maktul ve mağdura yönelik eylemleri sebebiyle ayrı ayrı değerlendirme yapılarak sanığın hukuki durumunun değerlendirilmesi ve sonucuna göre hüküm kurulması gerektiği gözetilmeksizin"şeklinde değerlendirme yapmıştır, 1. CD, 08.05.2017, E. 2017/115, K. 2017/1481. Aynı yöndeki bir başka kararında, "uyuşmazlık, sanığın eyleminin doğrudan kastla öldürmeye teşebbüs mü, yoksa olası kastla yaralama suçunu mu oluşturduğunun belirlenmesine ilişkindir. Katılan ve maktülün içinde bulunduğu minibüsün geçişi sırasında sanığın 6-7 metrelik mesafeden cam kenarında oturan katılan ile yanında oturan maktülü hedef alarak av tüfeğiyle ardı ardına 3 
2010 yılında verdiği bir başka kararında birden fazla atışın olduğu ve birden fazla kişinin yaralandığ 1 olayda tek fiil olduğunu belirlemiş, ancak m. 43/3 nedeniyle ayrı ayrı sorumluluk tayin edileceğine karar vermiştir ${ }^{199}$. Ceza Kanunumuz da aslında 43/3 düzenlemesi nedeniyle kasten öldürme ve kasten yaralamalarda doğal anlamda tek fiilde bile 43/2'nin uygulanmasin1 kabul etmeyerek birden fazla fiilde doğal hareket tekliği belirlemesinin yapılamayacağ 1 sonucunu ortaya koymaktadır. Tek fiille hem öldürmenin hem de yaralamanın gerçekleştirildiği olaylarda TCK m. 43/3 gibi bir düzenlemenin TCK m. 44'te olmaması nedeniyle farklı nevi fikri içtimanın uygulanması gerektiği uygulamada ${ }^{200}$ ve doktrinde bazı yazarlar tarafindan

el ateş etmesi, maktülün sol omuz ve kol bölgesinden, katılanın boyun bölgesinden yaralanması, olayda kullanılan av tüfeğinin öldürmeye elverișli silah olması, av tüfeğinden atılan fişeklerin maktülün otopsi raporunda belirtildiği üzere saçma ile sıkıştırılmış bilye içerikli özel yapım fişekler olması, maktülde ölüm sonucunu oluşturan yaralanmaların dokuz gülle tabir edilen bilyelerin isabeti sonucu oluşması, katılana rastlantı sonucu bilye isabet etmemekle beraber hayati organlarının bulunduğu boyun bölgesine saçmaların isabet etmesi, sanığın cam kenarında oturan katılanı gördüğü halde eylemini gerçekleştirmesi, soruşturma aşamasında katılan ve maktulün bulunduğu bölgeye doğru ateş ettiğini açıkça ifade etmesi ve sanığın eylemi nedeniyle katılana göre daha iç bölgede oturan babasının öldüğü gerçeği karşısında, sanığın eylemini zorunlu ve kaçınılmaz sonuçlarını bilerek gerçekleştirdiğinin ve olay sırasında öldürme kastıyla hareket ettiğinin kabulü gerekmektedir. Bu nedenle, yerel mahkemece sanığın katılana yönelik eylemi nedeniyle kasten öldürme suçuna teşebbüsten cezalandırılmasında bir isabetsizlik bulunmamaktadır" şeklinde belirleme yapmıştır: CGK, 22.05.2012, E. 2011/1-480, K. 2012/207.

${ }^{199}$ CGK, 06.07.2010, E. 2010/8-51, K. 210/162.

200 “'sanık ...'1n aracından çıkardığı av tüfeğini yaklaşık 3-4 metre mesafede bulunan ...'a doğrultarak bir el ateş ettiğii, ...'un karın ve sağ üst bacak bölgesine isabet eden çok sayıda saçma tanesi ile ince bağırsakta meydana gelen delinmeler dolayısıyla yaşamsal tehlike geçirecek şekilde yaralandığı, .....'in yanında bulunan ve atış mesafesi, kullanılan silahın niteliği göz önüne alındığında, açılan ateş sonucu dağılacak saçma taneleri ile yaralanması hayat tecrübelerine göre mutlak olmayan ancak beklenebilen katılan ...'un ise bacağının sol tarafina isabet eden saçma taneleri ile basit bir tıbbi müdahale ile giderilebilecek şekilde aynı atış ile yaralandığı olayda; sanık ...'ın av tüfeği ile katılan ...'u öldürme amacıyla ona doğru bir kez ateş etme eyleminin hukuki anlamda tek fiil sayılması gerektiği ve bu suretle tek olan eylem sonunda hem katılan ...'a karşı kasten öldürme suçuna teşebbüsün, hem de katılan ...'a yönelik olası kastla yaralama suçunun meydana geldiği hususlarında şüphe bulunmadığ 1 , TCK'nın 43. maddesinin 3. fikrasındaki; "Kasten öldürme, kasten yaralama, işkence ve yağma suçlarında bu madde hükümleri uygulanmaz" hükmüyle, bu suçlarda zincirleme suç hükümleri ile aynı neviden fikri içtima kuralının uygulanmayacağı, dolayısıyla sayılan bu suçlarda, failin mağdur sayısınca ayrı ayrı cezalandırılacağına ilişkin istisna hükmüne TCK'nın 44. maddesindeki farklı neviden fikri içtima düzenlemesinde yer verilmemiş olması, kıyas veya genişletici yorum yoluyla, hakkında düzenleme olmayan bir ceza hukuku konusunda kişi hak ve hürriyetlerinin aleyhine uygulama geliştirilemeyeceği yönündeki evrensel hukuk ilkeleri birlikte değerlendirildiğinde, bir fiil ile birden fazla farklı suçun oluşmasına sebebiyet veren sanık hakkında 5237 Sayılı TCK'nın 44. maddesinin uygulanmas1 ve meydana gelen suçların en ağırı olan kasten öldürme suçuna teşebbüsten ceza verilme- 
kabul edilmektedir. Doktrindeki yazarlara göre, 43. maddenin 3. fikrasının uygulanması söz konusu olmayıp, 44. madde gereğince belirleme yapmak gerekir. Aksine uygulama kıyas yasağının ihlali anlamına gelmektedir ${ }^{201}$. Tek fiille kasten öldürme ile kasten yaralamanın gerçekleştirildiği olaylarda 43. maddenin 3. fikrası hükmünün uygulanması ve gerçek içtimanın kabul edilmesi kıyas yasağının ihlali anlamına geldiği (aleyhe kıyas olduğu için) görüşünü biz de kabul etmekteyiz. Suç ve ceza içeren hükümler dışında lehe olmak şartıyla kıyas yasağını kabul etmekle beraber, burada aleyhe kıyas yapılması nedeniyle kıyas yasağının bulunduğunu ifade etmek istiyoruz. Ancak bu şekilde uygulamanın da adil olmadığı ortadadır. Atılan bir kurşunla bir kişinin doğrudan, diğer bir kişinin ise sapma sonucunda muhtemel kastla öldürülmesi durumunda ya da tek fiille iki kişinin yaralandığ 1 olayda fail gerçek içtima kuralları gereğince sorumlu olurken, bir kişinin öldüğü diğer bir kişinin yaralandığı olayda sadece öldürmeden ceza uygulamak (TCK m. 44 gereğince), yaralamayı göz önüne almamak TCK'nın 3. maddesinde düzenlenen orant1l1lı ilkesine uygun nitelik taşımamaktadır ${ }^{202}$. Doğru olan gerçek içtimanın uygulanmasıdır. Bunun için kanunda değişikliğe gidilmesinin daha doğru olacağını düşünmekteyiz.

\section{YAPTIRIM}

Kasten öldürme suçunun temel şeklinin cezası müebbet hapis cezasıdır. TCK'da cezanın daha az verilmesini gerektiren nitelikli hal düzenlenmediği için suçun karşıllğında öngörülen en düşük ceza müebbet hapis cezasıdır. Bu cezanın çok yüksek olduğunu belirtmek istiyoruz. Ayrıca cezanın maktu nitelikte öngörülmesi de doğru olmamıştır. Eğer kanun koyucu bu şekilde belirleme yapıyorsa suçun daha az ceza verilmesini gerektiren nitelikli hallerine de yer vermeliydi. Ĕger bunu yapmıyorsa cezanın maktu şekilde bu kadar yüksek belirlenmemesi, asgari ve azami hadler arasında cezanın öngörülmesi gerekiyordu. Hakime temel cezada somut olayın şartlarına göre cezayı belirleme imkanı tanınmalıydı. Bu yapılmadığı için cezanın daha az verilmesini gerektiren nedenler sadece 62. madde çerçevesinde göz önüne alınmaktadır. Oysa cezanın asgari ve azami hadler arasında öngörülmesi

si, bunun dışında katılan ...'a yönelik olası kastla yaralama suçundan ayrıca mahkûmiyet hükmü kurulmaması gerekmektedir", CGK, 18.10.2018, E. 2015/1-158, K. 2018/444. Ayn1 yönde CGK, 28.1.2020, E. 2019/1-350, K. 2020/30.

${ }^{201} \mathrm{Koca} / \mathrm{U} z u ̈ l m e z$, Genel Hükümler, s. 543. Gerçek içtimanın uygulanmasına ilişkin olarak bkz.: Özgenç, Türk Ceza Hukuku, s. 655, dipnot 1164.

${ }^{202}$ Bkz.: Akbulut, Zincirleme Suç\&Fikri İçtima, s. 166. 
söz konusu olsaydı, işlenen fiilin haksızlık içeriğine göre hakim cezayı belirleyebilirdi. Böyle olmadığı, ceza maktu şekilde öngörüldüğü için 82. madde dişında gerçekleştirilen tüm öldürmelere müebbet hapis cezası verilmektedir ki bunun yerinde olmadığ 1 belirtilmelidir. Kanun koyucunun hem maktu ceza belirlemesi yapmasının hem de bu cezanın müebbet hapis cezası şeklinde yüksek olmasının uygulama açısından sorun teşkil ettiğini düşünüyoruz. Zira uygulamada ceza miktarını düşürmek için değişik yollara gidilmesi söz konusu olmakta, uygulanmaması gereken müesseseler tatbik edilmektedir. Başka ülkelerin düzenlemesine bakıldığında Almanya'da suçun temel cezasının 5 yıldan az olmamak üzere hapis olduğu, çok ağır hallerde müebbet hapis cezası verildiği (m. 212), Avusturya'da 5 yıldan 10 yıla kadar hapis cezası öngörüldüğ̈̈ (m. 76), İspanya'da 10 yıldan 15 yıla kadar hapis cezası olarak hükme bağlandığı (m. 138), Rusya'da 6 yıldan 15 yıla kadar hapis cezası belirlendiği (m. 105), Fransa'da 30 yıla kadar hapis şeklinde tespit edildiği (m. 221-1), Portekiz'de ise 8 yıldan 16 yıla kadar hapis cezası öngörüldüğ̈̈ (m. 131) görülmektedir. Irak Ceza Kanununda ise, kasten öldürmenin cezası müebbet hapis cezası veya süreli hapis cezas1 olarak ifade edilmiştir. Anglosakson sitemine dahil Kanada'da ise cinayet (öldürme) birinci veya ikinci derece olarak sinıflandırılmakta ve her iki öldürmeye de müebbet hapis cezası verileceği düzenlenmektedir.

Kasten öldürme suçunu işleyen kişiye ceza dışında güvenlik tedbiri de uygulanabilir. TCK'nın 53. maddesinde yer alan hak yoksunluğu, 54. ve 55. maddelerinde yer alan müsadere güvenlik tedbiri uygulanabilecektir. Kusur yeteneği olmayan ve öldürme suçunu işleyen akıl hastaları veya çocuklar için de güvenlik tedbirine karar verilebilecektir.

Kasten öldürme suçu terör örgütünün faaliyeti çerçevesinde işlendiği takdirde, terör suçu sayılmaktadır (TMK m. 4).

\section{SONUÇ}

Türk Ceza Kanunun 81. maddesinde düzenlenen kasten öldürme suçu ülkemizde uygulaması fazla olan bir suç özelliği taşımaktadır. Özellikle kadına yönelik şiddet kapsamında kadınların mağdur olduğu bir suç grubudur. Çok işlenmesi nedeniyle de yargı kararları bu suç grubunda önemli bir yer tutmaktadır. Ancak suçun işlenmesinin çokluğu ve suça uygulanacak birçok müessesenin varlığ1 (kast, meşru savunma, kanun hükmünün yerine getirilmesi, sınırın aşılması, sapma, iştirak gibi) uygulamada sorun yaşanması sonucunu doğurmaktadır. Aynı zamanda doktrinde de tartışmalar 
yaşanmaktadır. Ayrıca inceleme konumuzun dışında kalması nedeniyle bahsetmemekle beraber nitelikli hallerin düzenlenmesinde sorun bulunmas1 nedeniyle suçun temel şekli ile nitelikli şeklinin uygulanması açısından da çelişkiler söz konusu olmaktadır. Aslında nitelikli hal olması gerekirken düzenleme gereğince suçun temel şeklinin uygulanması yoluna gidilmekte ve bu da suçla mücadele açısından yerinde bir tercih niteliği taşımamaktadır. Ayrıca ceza miktarının yüksekliği ve maktu ceza öngörülmesi hakime somut olayın şartlarına göre cezayı belirleme imkanı vermemektedir.

\section{KAYNAKÇA}

Akbulut, Berrin, Ceza Hukuku, Genel Hükümler, 6. Bask1, Adalet Yayınevi, Ankara, 2019.

Akbulut, Berrin, "Zincirleme Suç\&Fikri İçtima”, HPD, Sonbahar 2004, Sa. 2, s. 163-167.

Alacakaptan, Uğur, İşlenemez Suç, Ankara Üniversitesi, Ankara, (tarihsiz).

Alacakaptan, Uğur, Suçun Unsurları, Ankara Üniversitesi, Ankara, 1970.

Alan-Akcan, Esra, “Ötanazi”, İÜHFM, C. LXXI, Sa. 1, s. 3-26.

Artuk, Mehmet Emin, "Talep Üzerine Öldürme", Hukuk Araştırmaları Dergisi, C. VII, Sa. 1-3, 1992-1993, s. 19-40.

Artuk, M. Emin/Gökcen, Ahmet, Ceza Hukuku, Genel Hükümler, (M. Emin Artuk, Ahmet Gökcen, M. Emin Alşahin, Kerim Çakır), 11. Bask1, Adalet Yayınevi, Ankara, 2017.

Artuk, M. Emin/Gökcen, Ahmet, Ceza Hukuku, Özel Hükümler, (M. Emin Artuk, Ahmet Gökcen, M. Emin Alşahin, Kerim Çakır), 16. Baskı, Adalet Yayınevi, Ankara, 2017.

Avcı, Mustafa, Osmanlı Ceza Hukuku, Genel Hükümler, Mimoza Yayınevi, Konya, 2010.

Bafra, Jale, "Tibbi Müdahalelerde Hekimin Cezaî Sorumluluğu”, İBD, 1993, C. 69 , Sa. 1-2-3, s. 112- 133. 
Bayraktar, Köksal, Hekimin Tedavi Nedeniyle Cezaî Sorumluluğu, İstanbul Üniversitesi, İstanbul, 1972.

Bohnert, Joachim, OWİG Ordnungswidrigkeitengesetz, Kommentar, 2. Auflage, C.H. Beck, München, 2007.

Centel, Nur/Zafer, Hamide/Çakmut, Özlem, Kişilere Karşı İşlenen Suçlar, C. I, Beta Basım Yayın, İstanbul, 2017.

Centel, Nur/Zafer, Hamide/Çakmut, Özlem, Türk Ceza Hukukuna Giriş, 10. Bası, Beta Basım Yayın, İstanbul, 2017.

Cin, M. Onursal, “Kolluğun Zor Kullanma Yetkisi”, Selçuk Üniversitesi Hukuk Fakültesi Dergisi: Milenyum Armağanı, C. 8, 2000, Sa.1-2, s. 665-686.

Demirbaş, Timur, Ceza Hukuku, Genel Hükümler, 13. Bask1, Seçkin Yayıncilik, Ankara, 2018.

Doğru, Osman, Yaşama Hakkı, Anayasa Mahkemesine Bireysel Başvuru El Kitapları Serisi-5, anayasa.gov.tr (12.05.2020).

Dönmezer, Sulhi, Kişilere ve Mala Karşı Cürümler, 16. Bası, Beta Basım Yayın, İstanbul, 2001.

Dönmezer, Sulhi/Erman, Sahir, Nazari ve Tatbiki Ceza Hukuku, Genel Kısım, C. I, (Köksal Bayraktar/Serap Keskin Kiziroğlu/Hamide Zafer/ Hasan Sınar/R. Murat Önok/R. Barış Erman), 14. Bası, DER Kitabevi, İstanbul, 2016.

Dönmezer, Sulhi/Erman, Sahir, Nazari ve Tatbiki Ceza Hukuku, Genel Kısım, C. I, 13. Tıpk1 Bası, Beta Basım Yayın, İstanbul, 1997.

Dönmezer, Sulhi/Erman, Sahir, Nazari ve Tatbiki Ceza Hukuku, Genel

Kısım, C. II, Onbirinci Bası, Beta Basım Yayın, İstanbul, 1997.

Engländer, Armin, Grund und Grenzen der Nothilfe, Mohr Siebeck, Tübingen, 2008.

Ekici-Şahin, Meral, Ceza Hukukunda Rıza, On İki Levha Yayıncılık, İstanbul, 2012.

Erem, Faruk, Ümanist Doktrin Açısından Türk Ceza Hukuku, Özel Hükümler, C. IV, Üçüncü Baskı, Seçkin Kitabevi, Ankara, 1985.

Erem, Faruk/Danışman, Ahmet/Artuk, Mehmet Emin, Ceza Hukuku, Genel Hükümler, 14. Bask1, Seçkin Yayınc1lık, Ankara, 1997.

Erman, Sahir/Özek, Çetin, Ceza Hukuku Özel Bölüm, Kişilere Karşı 
İşlenen Suçlar, Dünya Yayıncılık, İstanbul, 1994.

Gökcen, Ahmet, Tanzimat Dönemi Osmanlı Ceza Kanunları ve Bu Kanunlardaki Ceza Müeyyideleri, Yayınevi yok, İstanbul, 1989.

Gökcen, Ahmet/Balc1, Murat, Kasten Öldürme Suçları (TCK m. 81-83), Seçkin Yayıncılık, Ankara, 2013.

Gökcen, Ahmet/Balcı, Murat, "Kasten Öldürme Suçu (TCK. M. 81)”, MÜHFHAD, C. 17, Sa. 1-2, s. 95-218.

Gropp, Walter, Strafrecht, Allgemeiner Teil, 3. Auflage, Springer, Berlin 2005.

Hafızoğulları, Zeki/Özen, Muharrem, Türk Ceza Hukuku, Özel Hükümler, Kişilere Karşı Suçlar, 2. Baskı, US-A Yayıncılık, Ankara.

Hafizoğulları, Zeki/Ketizmen, Muammer, "5237 sayılı Türk Ceza Kanunu’nda Hayata karşı Suçlar”, Ankara Barosu Dergisi, Y1l 66, Sa. 1, 2008, s. 143-154.

Hafızoğulları, Zeki/Özen, Muharrem, Türk Ceza Hukuku, Genel Hükümler, 4. Baskı, US-A Yayınc1lık, Ankara, 2011.

Hakeri, Hakan, "Yargıtay Kararlarında Nedensellik Bağı", Alman-Türk Karşılaştırmalı Ceza Hukuku: C. III, Prof. Dr. Köksal Bayraktar'a Armağan, İstanbul 2010, s. 93-110.

Hakeri, Hakan, Ceza Hukuku, Genel Hükümler, 22. Bask1, Adalet Yayınevi, Ankara, 2019.

Hakeri, Hakan, Kasten Öldürme Suçları, TCK m. 81-82-83, 2. Bask1, Seçkin Yayıncılık, Ankara, 2007.

Hakeri, Hakan, Tıp Hukuku, 10. Baskı, Seçkin Yayıncılık, Ankara, 2015.

Hakeri, Hakan, Tıp Hukuku, 17. Baskı, Seçkin Yayıncılık, Ankara, 2019.

Hakeri, Hakan, Ceza Hukukunda İhmal Kavramı ve İhmali Suçların Çeşitleri, Seçkin Yayıncılık, Ankara, 2003.

Heinrich, Bernd, Ceza Hukuku, Genel Kısım-I, Editör: Yener Ünver, Adalet Yayınevi, Ankara, 2014.

Honig, Richard, (Çev.: Yavuz Abadan), “illiyet Nazariyesine Dair”, İÜHFM, 1936, Sa. 1-4, s. 169-188.

İçel, Kayıhan, Ceza Hukukunda Taksirden Doğan Sübjektif Sorumluluk, İstanbul Üniversitesi, İstanbul, 1967. 
İçel, Kayıhan/Sokullu-Akıncı, Füsun/Özgenç, İzzet/Sözüer, Adem/ Mahmutoğlu, Fatih M./Ünver, Yener, Suç Teorisi, 2. Kitap, 2. Bası, Beta Basım Yayın, İstanbul, 2000.

İlhan, Abdulkadir/Erel, Kemalettin/Fazla, Yüksel/Örer, Fatma Betül/Çakıl, Dursun/Köse, Mehmet/Halitoğlu, Coşkun/Bozoğlu, Süleyman/Kurşun, Ömer Faruk/Kır, Oğuzhan, Yargitay Ceza Genel Kurulu Kararları (2005-2015), Adalet Yayınevi, Ankara, 2015.

Jescheck, Hans Heinrich, Lehrbuch des Strafrechts, Allgemeiner Teil, 4. Auflage, Duncker\&Humblot, Berlin, 1988.

Jescheck, Hans-Heinrich/Weigend, Thomas, Lehrbuch des Strafrechts, Allgemeiner Teil, 5. Auflage, Duncker\&Humblot, Berlin, 1996.

Karlsruher Kommentar zum Gesetz über Ordnungswidrigkeiten, 3., neu bearbeitete Auflage, C.H. Beck, München, 2006.

Kelsen, H., (Çev.: Zeki Hafızoğulları), "Nedensellik ve İsnadiyet", AÜHFD, 1978, C. 35, Sa. 1-4, s. 219-233.

Koca, Mahmut/Üzülmez, İlhan, Türk Ceza Hukuku, Özel Hükümler, 5. Bask1, Adalet Yayınevi, Ankara, 2018.

Koca, Mahmut/Üzülmez, İlhan, Türk Ceza Hukuku, Genel Hükümler, 12. Baskı, Seçkin Yayıncılık, Ankara, 2019, 12. Bask1.

Kunter, Nurullah, Suçun Maddi Unsurları Nazariyesi (Hareket-NeticeSebebiyet Alakası), İsmail Akgün Matbaası, İstanbul, 1955.

Leipziger Kommentar zum Strafgesetzbuch, Erster Band, 11., neu bearbeitete Auflage, De Gruyter, Berlin, 2003.

Mahmutoğlu, Fatih Selami/Karadeniz, Serra, Türk Ceza Kanunu Genel Hükümler Şerhi, Beta Basım Yayın, İstanbul, 2017.

Mitsch, Wolfgang, Recht der Ordnungswidrigkeiten, 2. Auflage, Springer, Berlin Heidelberg, 2005.

Otacı, Cengiz, Genel Hükümlerle Bağlantılı Olarak Kasten İnsan Öldürme Suçları, 2. Baskı, Adalet Yayınevi, Ankara, 2016.

Önder, Ayhan, Ceza Hukuku Dersleri, Filiz Kitabevi, İstanbul, 1992.

Önder, Ayhan, Şahıslara ve Mala Karşı Cürümler ve Bilişim Alanında Suçlar, Filiz Kitabevi, İstanbul, 1994.

Önder, Ayhan, Ceza Hukuku, Genel Hükümler, C. II-III, Yenilenmiş II. 
Bası, Beta Basım Yayın, İstanbul, 1992.

Özbek, Veli Özer, "Ceza Hukukunda Nedensellik Bağı ve Fiilin Objektif İsnad Edilebilirliği Sorunu”, Baki Kuru'ya Armağan, Ankara, 2004, s. 417-477.

Özbek, Veli Özer/Doğan, Koray/Bacaksız, Pınar, Türk Ceza Hukuku, Özel Hükümler, 14. Baskı, Seçkin Yayıncılık, Ankara, 2019.

Özbek, Veli Özer/Doğan, Koray/Bacaksız, Pınar, Türk Ceza Hukuku, Genel Hükümler, 10. Baskı, Seçkin Yayıncılık, Ankara, 2019.

Özek, Çetin, "Tıbbi Müdahalelerden Doğan Sorumlulukla İlgili Genel Prensipler", İstanbul Tıp Fakültesi Mecmuası, 1966, C. 29, Sa. 1, s. 160-170.

Özgenç, İzzet, Türk Ceza Hukuku, Genel Hükümler, 15. Bası, Seçkin Yayınc1lı, Ankara, 2019.

Özgenç, İzzet, Suça İştirakin Hukuki Esası ve Faillik, İ.B.B. Hukuk Müşavirliği, İstanbul, 1996.

Öztürk, Bahri/Erdem, Mustafa Ruhan, Uygulamalı Ceza Hukuku ve Güvenlik Tedbirleri Hukuku, 19. Baskı, Seçkin Yayıncılık, Ankara 2019.

Roxin, Claus, Strafrecht, Allgemeiner Teil, Grundlagen Der Aufbau Der Verbrechenslehre, Band I, 4. Auflage, C.H. Beck, München, 2006,

Selçuk, Sami, "Karşılaş̧ırmalı Hukuk Açısından Canavarca His Sevkiyle Adam Öldürme", Yargıtay Dergisi, C. 14, 1988, Sa. 4, s. 467-482.

Soyaslan, Doğan, Teşebbüs Suçu, Kazancı Kitap, Ankara, 1994.

Soyaslan, Doğan, Ceza Hukuku, Genel Hükümler, 5. Bask1, Yetkin Yayınevi, Ankara, 2012.

Strafgesetzbuch, Kommentar, 28., neubearbeitete Auflage von Eser, Albin/ Heine, Günter/Perron, Walter/Sternberg-Lieben, Detlev/Eisele, Jörg/ Bosch, Nikolaus/Hecker, Bernd/Kinzig, Jörg/ Schittenhelm, Ulrike, C.H. Beck, München, 2010.

Sözüer, Adem, Suça Teşebbüs, Kazancı Kitap, İstanbul, 1994.

Tezcan, Durmuş/Erdem, Mustafa Ruhan/Önok, Murat, Teorik ve Pratik Ceza Özel Hukuku, 17. Baskı, Seçkin Yayıncılık, Ankara 2019.

Toroslu, Nevzat, Ceza Hukuku, Genel Kısım, Savaş Yayınevi, Ankara, 2014. 
Tröndle, Herbert/Fischer, Thomas, Strafgesetzbuch und Nebengesetze, 53. Auflage, C.H. Beck, München, 2006.

Üçok, Coşkun, "Osmanlı Kanunnamelerinde İslam Ceza Hukukuna Aykırı Hükümler, AÜHFM, 1947, C. IV, Sa. 1-4, s. 48-73.

Ünver, Yener, Ceza Hukukunda İzin Verilen Risk, Beta Basım Yayın, İstanbul, 1998.

Yaşar, Yusuf/Turan, Iş1l, "Alman, Avusturya ve İsviçre Yüksek Mahkeme Kararları Çerçevesinde Talep Üzerine Öldürme Suçu ile Ötanazi İlişkisi”, MÜHF-HAD, C. 19, Sa. 1, s. 39-72.

Yüce, Turhan Tufan, Ceza Hukuku Dersleri, C. I, Şafak Basım ve Yayınevi, Manisa, 1982.

Zafer, Hamide, Ceza Hukuku, Genel Hükümler, TCK m. 1-75, 7. Bas1, Beta Basım Yayın, İstanbul, 2019. 
